Report No: 106597-PH

Republic of the Philippines

Review of the Social Security System

Considerations for Strengthening Sustainability and Coverage

June 23, 2016

Social Protection, Labor and Jobs Global Practice

East Asia and Pacific Region

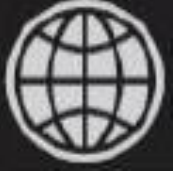




\section{Philippines - Review of the Social Security System}

\section{Abbreviations and Acronyms}

$\begin{array}{ll}\text { AlkanSSSya } & \text { SSS program for social security for informal sector workers } \\ \text { AMSC } & \text { Average monthly salary credit (SSS) } \\ \text { AMC } & \text { Average monthly compensation (GSIS) } \\ \text { BIR } & \text { Bureau of Internal Revenue } \\ \text { BMP } & \text { Basic monthly pension } \\ \text { CPI } & \text { Consumer price index } \\ \text { CYS } & \text { Calendar year of service (SSS) } \\ \text { DB } & \text { Defined benefit } \\ \text { DC } & \text { Defined contribution } \\ \text { DSWD } & \text { Department of Social Welfare and Development } \\ \text { DTI } & \text { Department of Trade and Industry } \\ \text { EAP } & \text { East Asia and Pacific } \\ \text { GOCC } & \text { Government-owned and controlled corporation } \\ \text { GSIS } & \text { Government Service Insurance System } \\ \text { HDMF } & \text { Home Development Mutual Fund } \\ \text { ILO } & \text { International Labour Organization } \\ \text { ISGs } & \text { Informal sector groups } \\ \text { LGUs } & \text { Local government units } \\ \text { MC } & \text { Monthly compensation } \\ \text { NHTS-Listahanan } & \text { National Household Targeting System } \\ \text { NDC } & \text { Notional defined contribution } \\ \text { NSO } & \text { National Statistical Office } \\ \text { OECD } & \text { Organisation for Economic Co-operation and Development } \\ \text { OFWs } & \text { Overseas Filipino Workers } \\ \text { Pag-IBIG } & \text { National Mortgage Savings Fund } \\ \text { PAYG } & \text { Pay-as-you-go } \\ \text { PERA } & \text { Personal equity and retirement account } \\ \text { PMT } & \text { Proxy means test } \\ \text { PhilHealth } & \text { Filipino Health Insurance (scheme and agency) } \\ \text { PHP } & \text { Filipino pesos } \\ \text { p.p. } & \text { Percentage point } \\ \text { PROST } & \text { Pension Reform Options Simulation Toolkit } \\ \text { SSS } & \text { Social Security System } \\ \text { UMID } & \end{array}$




\begin{abstract}
This report was prepared at the request of the Philippines Social Security System (SSS) to analyze key challenges and propose reform options to improve the sustainability and expand the coverage of old age income protection for private sector workers. A simulation employing the Pension Reform Options Simulation Toolkit (PROST) found that the SSS scheme will face outflows greater than inflows in about 20 years and depletion of its assets in about 28 years. Fortunately, its medium-term financing issues can be addressed through the gradual introduction of parametric reforms that shield workers and retirees from abrupt changes in contributions and benefits. At the same time, the Philippines faces a challenge to improve the defacto coverage of workers by Social Security, and to increase the income protection coverage of the elderly. Options suggested include SSS measures to leverage its identification system and introduce a special instrument for informal workers. Rather than introducing matching contribution subsidies to expand coverage, it was suggested to broaden the scope of beneficiaries eligible for social pensions. Beyond the scope of the SSS, additional measures were suggested including those to improve the access and efficiency of contributions and payments systems, strengthening mobile-money platforms and efforts to improve access to savings instruments, particularly for small and isolated savers. The report points out that the key means of improving coverage lies beyond the scope of social security or pensions, namely, to improve the quantity and quality of wage-based employment.
\end{abstract}

\title{
Acknowledgements
}

This report was prepared by Mark Dorfman and Tatyana Bogomolova of the Social Protection and Labor Global Practice of the World Bank in response to a request by the Philippines Social Security System (SSS). The report was prepared as part of the World Bank Group Philippines Programmatic Analytical and Advisory Activities Project in Social Protection and Labor (P148753) under the guidance of Aleksandra Posarac, Lead Economist and Program Leader for Human Development and Poverty in the Philippines. Peer reviewers were Robert Palacios and Philip O'Keefe. The regional practice manager overseeing the work was Jehan Arulpragasam. The team preparing the report benefited significantly from open discussions with staff of the SSS, GSIS, and DSWD over 2015-16. Training in the use of the Pension Reform Options Simulation Toolkit (PROST) was undertaken for SSS staff in Manila in May 2015. The report has benefited from earlier World Bank reports, particularly on jobs and labor markets. ${ }^{1}$

\footnotetext{
${ }^{1}$ See World Bank, 2013. Philippine Development Report: Creating More and Better Jobs; and World Bank, 2016. Republic of the Philippines: Labor Market Review - Employment and Poverty.
} 


\section{Table of Contents}

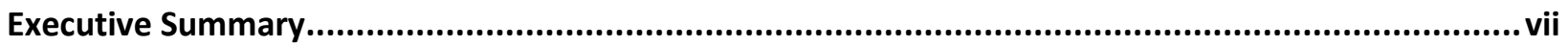

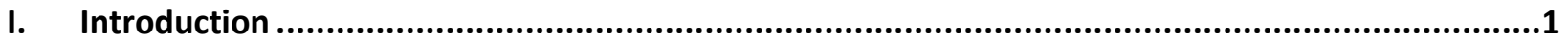

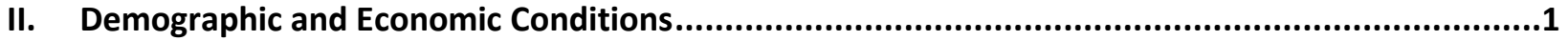

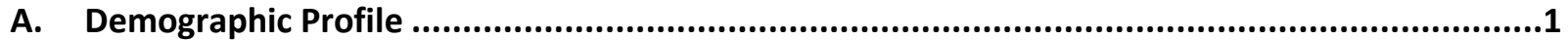

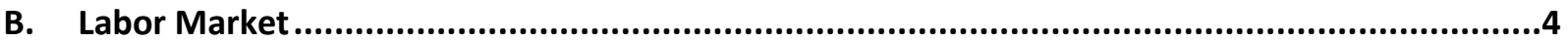

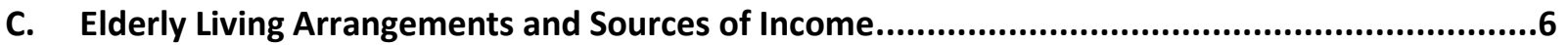

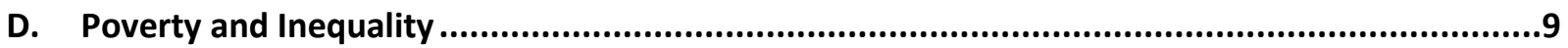

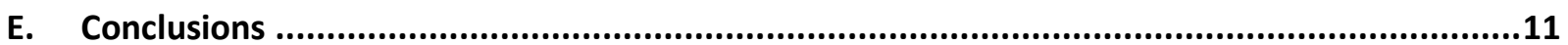

III. Social Security and Pension Programs for Private Sector Workers.........................................11

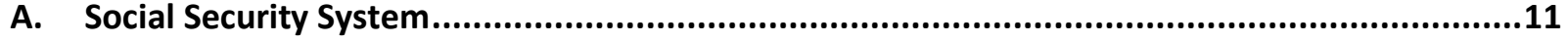

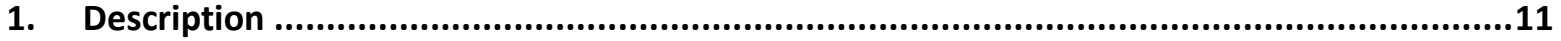

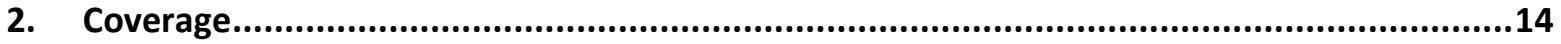

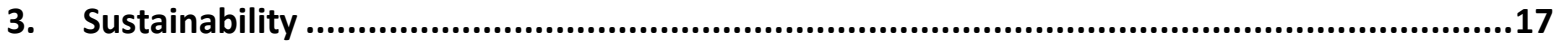

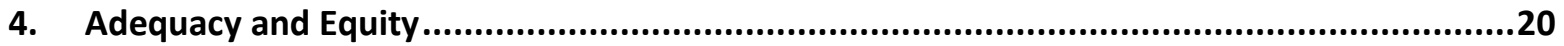

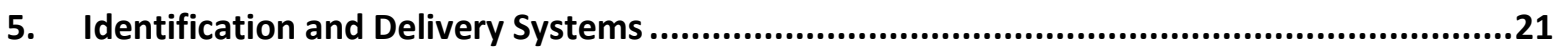

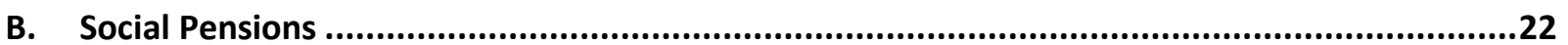

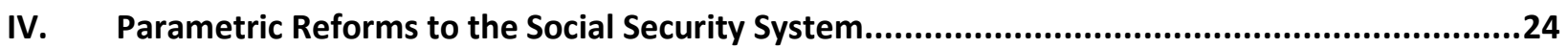

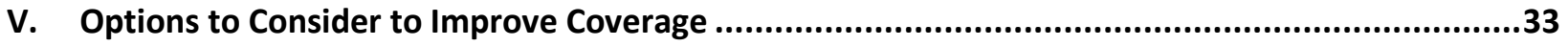

A. Overall Considerations to Increase Social Security Coverage and Income Protection in Old Age..

B. SSS Measures to Increase Coverage ..........35

C. Beyond SSS - Inter-Institutional Delivery System, Savings Options, and Broadening Eligibility for

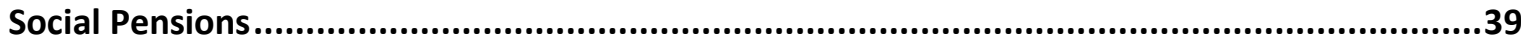

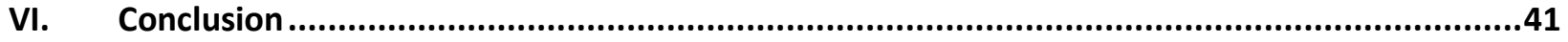

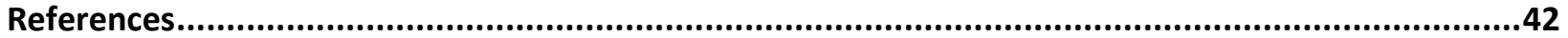

Annex 1: Main Assumptions used in PROST Projections ..............................................................44

Annex 2: General Description of PROST Methodology...................................................................46

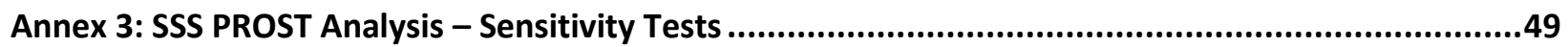




\section{Tables}

Table 1: $\quad$ Measures of Informality for Wage Workers …................................................................. 5

Table 2: $\quad$ Elderly Sources of Income by Household Type .................................................................. 9

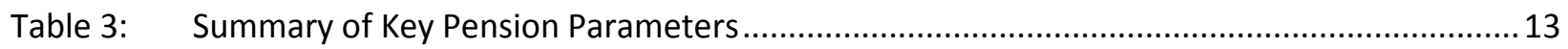

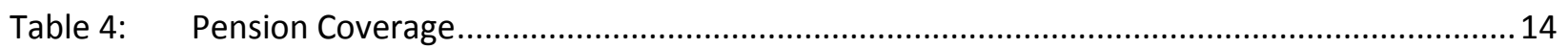

Table 5: Indicators of Sustainability of Public Defined Benefit Schemes in Selected Countries ........... 20

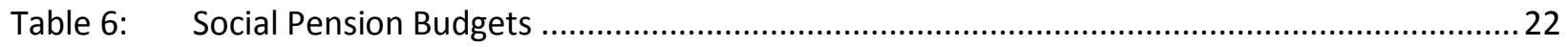

Table 7: $\quad$ Summary of Elderly Assistance Programs in the East Asia and Pacific Region .......................23

Table 8: $\quad$ Summary of SSS Parametric Reform Packages and Their Impacts .......................................25

Table 9: $\quad$ Summary of the Financial Effects of SSS Baseline and Simulated Reforms ............................26

Table 10: Illustrative Contributions at Different Contribution Rates ................................................. 32

Table 11: Life Expectancy at Various Ages by Gender ..................................................................... 44

Table 12: Macroeconomic Assumptions Used in PROST Projections ....................................................45

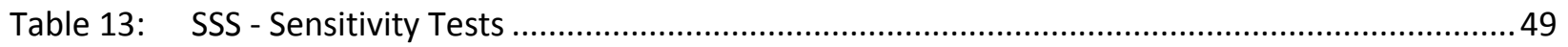




\section{Figures}

Figure 1: Projected Population and SSS System Dependency Ratios ................................................. 4

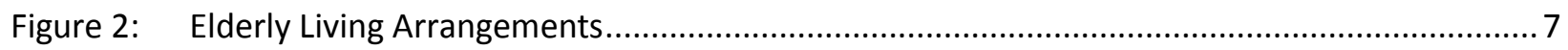

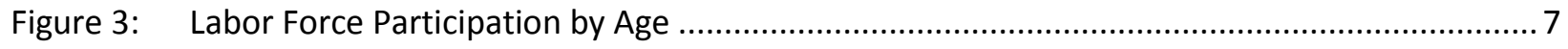

Figure 4: Proportion of Elderly Employed \& Employment Status ................................................... 8

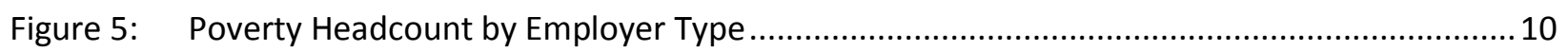

Figure 6: Poverty Headcount Incidence and Share by Five-Year Cohorts ........................................... 10

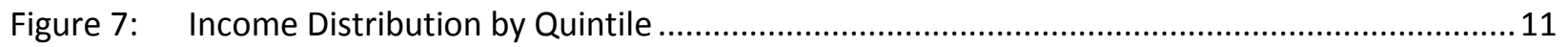

Figure 8: Correlation between Global Coverage and GDP Per Capita................................................ 15

Figure 9: $\quad$ SSS - Baseline Projection of Pension System Finances ..................................................... 18

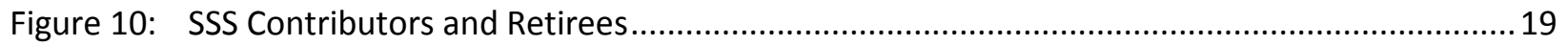

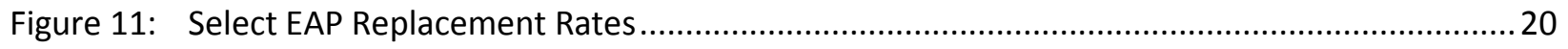

Figure 12: Benefits from Contributory Pensions .......................................................................... 21

Figure 13: SSS - Baseline and Reforms A, B, \& C - Impact on Sustainability - Annual Current Balance......

Figure 14: SSS - Impact of Reform Packages on Sustainability - Annual Current Balance ........................28

Figure 15: SSS - Impact of Reform Packages on All Retirees' Replacement Rate.................................. 30

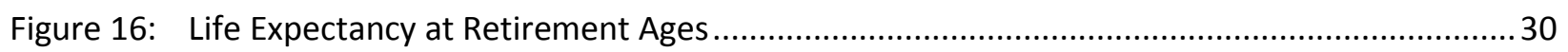

Figure 17: Life Expectancy at Retirement Ages in East Asia ............................................................... 31

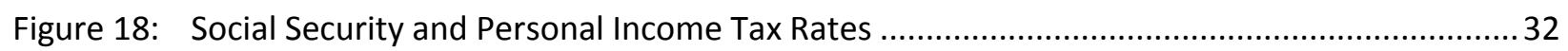

Figure 19: SSS Reforms - Summary of Projected Financing Gaps and Break-Even Points ......................33

Figure 20: Stylized Diagram of Building Blocks for Savings and Social Insurance Aligned with the Needs

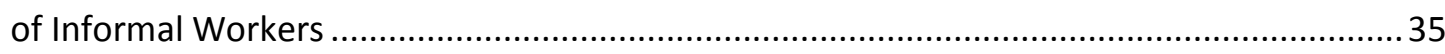

Figure 21: Average Income, Expenditure, and Savings of Families by Decile and Minimum Pension

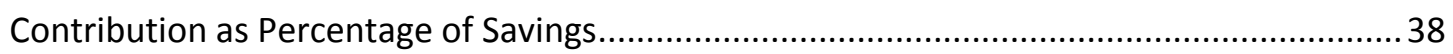

Figure 22: SSS - Sensitivity Test 1: Higher Life Expectancy at Retirement-Current Balance..................50

Figure 23: SSS - Sensitivity Test 1: Higher Life Expectancy at Retirement - Average Pension.................50

Figure 24: SSS - Sensitivity Test 2: Higher Coverage - Average Pension for New Retirees......................51

Figure 25: SSS - Sensitivity Test 2: Higher Coverage - Current Balance ..............................................51

Figure 26: SSS - Sensitivity Test 3: Not Indexing the Contribution Ceiling - Current Balance..................52

Figure 27: SSS - Sensitivity Test 3: Not Indexing the Contribution Ceiling - Average Pension.................52

Figure 28: SSS - Sensitivity Test 4: Increases in the Contribution Ceiling by PHP 200 per year - Current

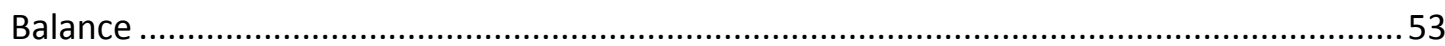

Figure 29: SSS - Sensitivity Test 4: Increases in the Contribution Ceiling by PHP 200 per year -

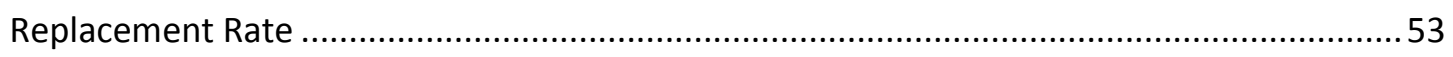

Figure 30: SSS - Sensitivity Test 5: Interest Rates on Pension Fund Investments Up/Down by 1 percentage point - Current Balance .54

\section{Boxes}

Box 1: Voluntary Occupational and Personal Pensions Arrangements........................................... 17

Box 2: $\quad$ Matching Contribution Programs to Extend Social Security Coverage .................................. 37 


\section{Philippines - Review of the Social Security System Executive Summary}

This report was prepared at the request of the Philippines Social Security System (SSS) to analyze key challenges and propose reform options to improve the sustainability and expand the coverage of old age income protection for private sector workers. Changes in qualifying conditions, contributions and benefits are proposed to improve the sustainability of the SSS, provide greater incentives to participate, and improve risk coverage. Measures are considered to improve coverage including new instruments aimed at informal workers, improving the efficiency of collections and payments and broadening the eligibility for a Social Pension.

Like many countries worldwide, Social Security in the Philippines faces challenges to its sustainability in part due to a gradual aging of the population. Over the next 35 years, the old-age dependency ratio (those over age 60 as a proportion of those who are working-age) is projected to almost double from about 12 percent in 2015 to 22.5 percent in 2050. Higher old age dependency ratios, coupled with little change in the relative size of the working-age population, will place increasing pressure on working-age individuals to provide support for elderly family members as well as on the country's social security system and other old age support programs. Projections of the SSS financial flows undertaken using the Pension Reform Options Simulation Toolkit (PROST) indicate that the scheme will face outflows greater than inflows in about 20 years and depletion of assets in about 28 years. At the same time, the SSS will continue to face the challenge of maintaining adequate SSS contributory benefits in the face of limited contribution histories, so that retirees have sufficient support in old age.

\section{Fortunately, the projected medium-term financing issues can be addressed through the gradual} introduction of parametric reforms that shield workers and retirees from abrupt changes in contributions and benefits. At the same time, some parametric reforms have been proposed to improve the participation incentives and risk coverage. These reforms could include the following: ${ }^{2}$

- Unify the SSS old-age benefit formula for all vested members to improve the incentives for participation and promote greater equity among workers with different incomes and lengths of service;

- Replace the current discretionary indexation of benefits with full and automatic inflation-based indexation to help protect retirees against inflation during retirement;

- Extend the wage base for determining benefits and "valorize" the wage base according to the average covered wage growth, which would equalize lifetime income replacement between those with high and low growth in lifetime wages as well as equalize effective income replacement between those whose base is during periods of rapid/slow wage growth;

- Gradually increase the retirement age to 65 years and increase it in the future in accordance with increases in life expectancy at retirement age, which will improve the sustainability of the SSS scheme;

- Gradually reduce the benefits accrued each year for service after a reform date to a level that achieves sustainability over the long term consistent with the other parameters; and

\footnotetext{
${ }^{2}$ PROST has been used to simulate these parametric reforms. These simulations provide the basis for an evidence based assessment.
} 
- The contribution rate could be gradually raised in the future to improve the long-term balance, although any increases need to be considered in the context of the overall tax wedge, as such measures will likely affect worker coverage and compliance which are also SSS objectives.

At the same time, the Philippines faces a challenge to improve the defacto coverage of workers by Social Security, as well as to increase the income protection coverage of the elderly. As with many countries, ensuring informal workers are de facto covered by contributory social security has proven to be particularly challenging as such workers generally have low and volatile incomes along with other social and health risks to consider. Around 75 percent of Filipino workers are informally employed and, while almost all workers are required to contribute, only about 22 percent of those employed actively contribute to the SSS (and another 3.4 percent to the Government Social Insurance System - GSIS). With this low labor force coverage, elderly coverage has also been challenging, albeit the Philippines has been fortunate to have a non-contributory Social Pension which protects the poorest elderly from poverty.

Going forward, a key challenge will be to increase both types of coverage level of such programs to ensure that a larger swath of workers contribute and ultimately benefit from their contributions. Worker coverage in the Philippines is below what it could be due to several factors, including high levels of informality in the labor market and characteristics in the design of the contributory social security scheme which may be ill suited to the variable incomes of informal sector workers.

Several options are suggested for the SSS to improve coverage. Administrative reforms could focus on measures to make it easier and cheaper for informal sector workers to make contributions, monitor accounts and receive payments. The identification system of the SSS including its de-duplication capability could also be leveraged to provide more unified identity across institutions. The SSS might also want to consider introducing a special instrument for informal workers which is designed to align with their needs and preferences. Such an instrument could be a voluntary, defined-contribution savings mechanism that offers annuitized benefits at retirement. It should permit partial withdrawals in the case of defined events such as extended unemployment, catastrophic health events or disability and natural disasters. Finally, the level and timing of contributions should be flexible to align to the variable incomes of informal workers.

Although several countries have considered matching contribution subsidies to expand coverage, our analysis suggests that a more effective alternative would be to broaden the scope of beneficiaries eligible for social pensions. The poor and vulnerable workers are unlikely to be able to afford the contribution and the fiscal costs could be substantial depending on the benefit level, match and targeting. Alternatively, broadening the scope of beneficiaries who are eligible for social pensions could increase elderly coverage with an immediate impact and in a more cost-effective manner.

Beyond the scope of the SSS, additional measures could strengthen the coverage of social protection for informal workers. Measures can be taken to improve the access and efficiency of contributions and payments systems, including measures to strengthen mobile-money platforms. Moreover further measures are needed to improve access to savings instruments, particularly for small and isolated savers. Finally, some further improvements to the strong Social Pension have been proposed, including broadening eligibility to the bottom 40 percent of eligible households; providing automatic annual price increases in benefits; conducting periodic program assessments of targeting outcomes; and conducting periodic reviews of the benefit adequacy. 
Improvements in SSS sustainability and the instruments and delivery systems for social security coverage comprise only one part of a broader strategy needed to better protect the vast majority of workers in the Philippines with low, intermittent and variable sources of income. The most important and sustainable remedy to improve social security coverage is to improve the quantity and quality of wage-based employment - measures which are beyond the scope of the SSS scheme design or delivery systems. Low worker coverage and contribution densities mirror the limited steady wage-based jobs for most Filipino workers. Low and intermittent incomes often from small companies or agriculture, selfemployed or single proprietors present formidable challenges both to economic stability as well as provide a weak basis for contributing to social security. Measures are needed to reduce the barriers to employment generation, which include a weak investment climate and costly business, tax, and labor market regulations. Moreover, weaknesses in skills need to be addressed. Overall, higher productivity jobs are essential for coverage expansion. Measures are needed on numerous fronts to strengthen the quality of growth and job creation including measures to combat the causes of informality, such as removing barriers to competition and growth in real sectors and addressing barriers to formality including taxes and labor market provisions. 
$-x-$ 


\section{Philippines - Review of the Social Security System}

\section{Introduction}

1. In early 2014, the Philippines Social Security System (SSS) that administers mandatory social security for the private sector workers in the Philippines, approached the World Bank, seeking advice on two key concerns: (i) how to increase the de facto coverage of social security (de jure, all employed persons in the Philippines are mandated to contribute to SSS), and (ii) how to ensure long term sustainability of the SSS. Regarding the latter, the SSS in particular wanted the World Bank team to check the SSS's own actuarial projections to make sure that they are technically robust. The World Bank team responded by simulating long term fiscal situation of the SSS, as well as several reform options employing the World Bank's Pension Reform Options Simulation Tool (PROST) and training the SSS actuarial team to use it.

\section{This report was undertaken in response to a request by the SSS and thus focuses on the SSS} although other pension and social security schemes such as the Government Service Insurance System (GSIS), Social Pensions, and voluntary pension savings instruments are highlighted. A separate note that looks at the GSIS is currently being prepared. In addition, the Philippines Social Protection Team is looking at the coverage and impact of the social pension program as part of the forthcoming Social Protection Review. Furthermore, while SSS provides old-age, disability and survivors' benefits, this report looks focuses on the old-age scheme.

\section{This report summarizes the World Bank team findings and recommendations in response to} the two key questions posed by the client. The report is organized as follows. The next section describes the demographic and economic conditions that affect the demand for and financing of pensions and social security in the Philippines. Section III then describes and discusses key programs for old age income protection, with particular emphasis on the SSS scheme. Section IV lays out options for parametric changes aimed at improving SSS sustainability and ensuring adequacy of benefits. Section $\mathrm{V}$ outlines various measures to expand the SSS coverage of the informal sector. The final section concludes with a summary of proposed reform options and longer-term considerations (Section VI).

\section{Demographic and Economic Conditions}

\section{A. Demographic Profile}

4. The Philippines is a young country compared to many other countries in the world. However, similar to many other countries and although with a lag, it is facing a challenge of an aging population in not so distant future. Compared to most of its regional peers, the pace of aging in the Philippines has been relatively slow. The Philippines had one of the youngest population profiles in the region in 2015 and is aging at a rate somewhat slower than most other countries. The pace of growth in old age dependency rates has also been slower and less severe for the Philippines than for other countries in East Asia and other middle-income countries (Figure 1), and the starting point in 2015 was less severe compared with most other countries in the region. 
Figure 1: $\quad$ Projected Population Old Age Dependency Ratios

(Age 65+/Age 15-64)

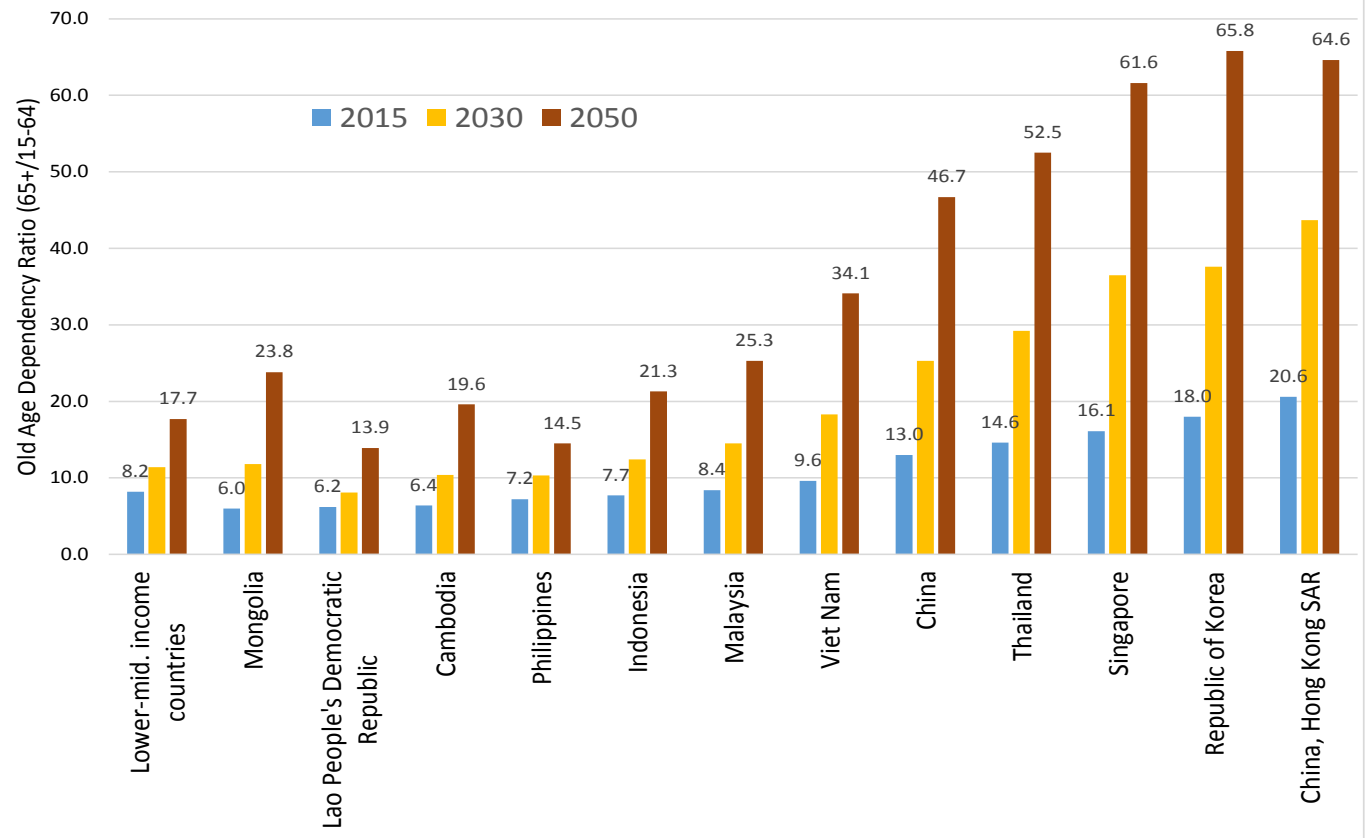

Source: United Nations Population Division, World Population Prospects, the 2015 Revision.

http://esa.un.org/unpd/wpp/DataQuery/

5. However, some convergence between countries is expected with the continued drop in fertility rates. The relative proportion of children in the overall population has declined, driven by a significant decline in fertility rates during the last 60 years: from 7.4 children per woman in 1950-55 to 3.0 in 20102015. The Philippines thus had one of the lowest dependency ratios compared with regional peers in 2015. Convergence is expected over the coming 35 years as many countries in the region are projected to approach replacement fertility of about 2.09 in the years ahead (Figure 2). ${ }^{3}$

\footnotetext{
${ }^{3}$ This is based on the middle fertility scenario of the UN Population Projections. See United Nations Population Division, World Population Prospects, the 2015 Revision.
} 
Figure 2: $\quad$ Philippines and Regional Fertility Rates - 1950-2055

(Children per woman)

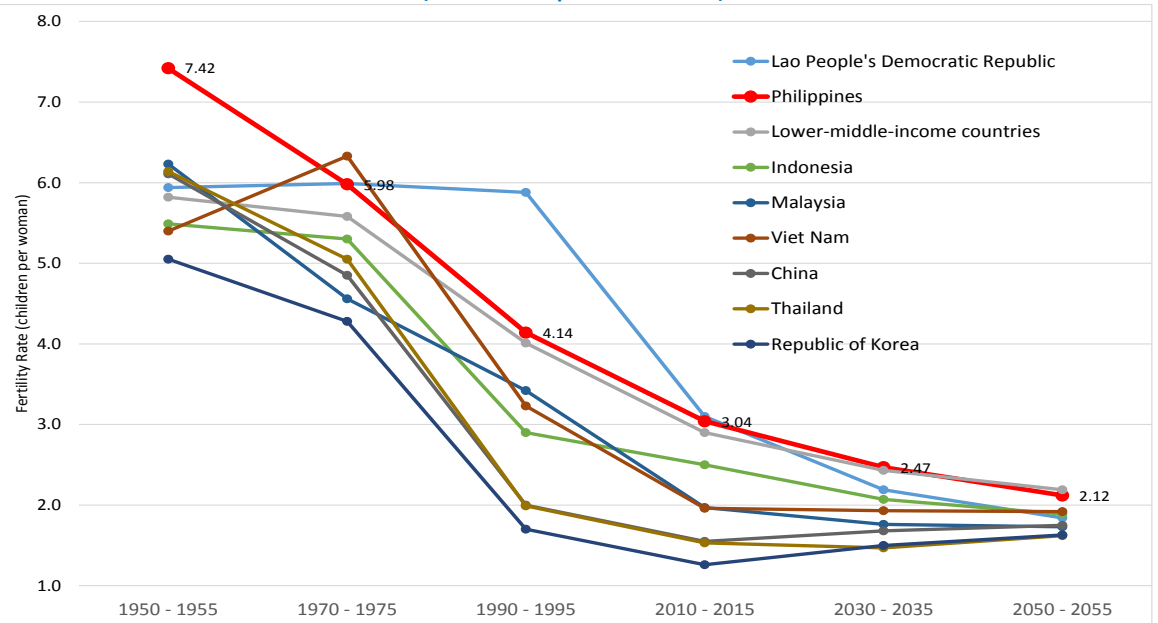

Source: United Nations Population Division, World Population Prospects, the 2015 Revision. http://esa.un.org/unpd/wpp/DataQuery/

6. The projected demographic trends signal that the Philippines will be facing the challenge of an aging population in not so distant future. The old-age dependency ratio (those over age 60 as a proportion of those who are working-age) is projected to almost double from about 12 percent in 2015 to 22.5 percent in 2050 (Figure 3). The aging of the population is projected to impact the economic and social landscape and the way people work and live, including on labor market participation well beyond current retirement age, the social security arrangements and their sustainability, the cost of health and elderly care and so on. The good news is that the Philippines is still a young country, with opportunities and time to learn from other faster aging countries.

Figure 3: $\quad$ Population by Broad Age Groups

(Millions - left axis, and percent right axis)

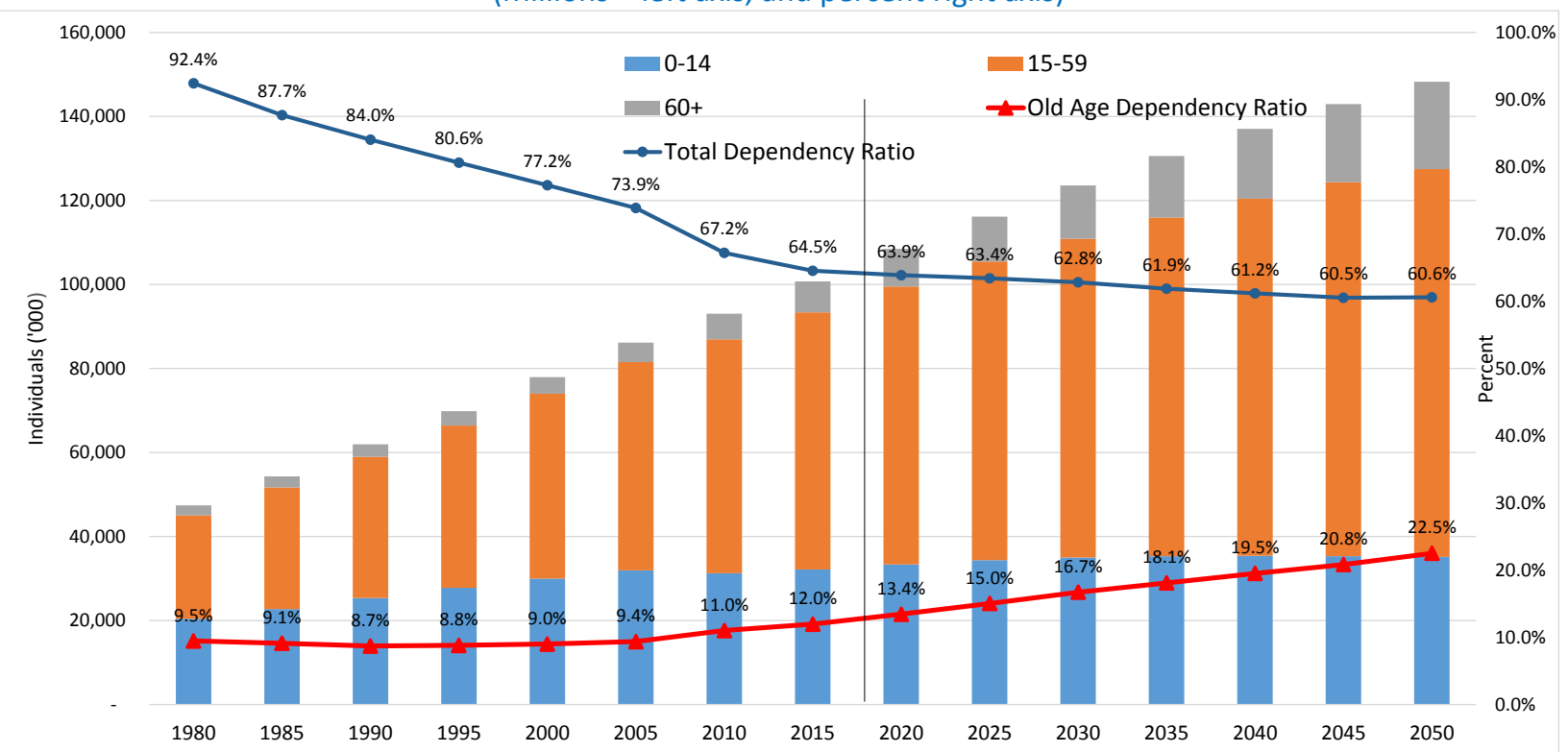

Source: United Nations Population Division, World Population Prospects, the 2015 Revision. http://esa.un.org/unpd/wpp/DataQuery/ 


\section{Workers covered by the SSS have considerably higher old age dependency ratios when} compared with the broader population, which is a key determinant in the sustainability of the SSS scheme (Figure 1). This is consistent with trends in other countries in the region, as fertility rates among the covered population tend to be lower than for the population as a whole, and life expectancy at retirement age also tends to be higher. A key reason for this may be that the current contributors and beneficiaries tend to be wealthier urban workers who have lower fertility rates and higher life expectancies and belong to the group of workers with formal employment and stable tenure.

Figure 1: $\quad$ Projected Population and SSS System Dependency Ratios

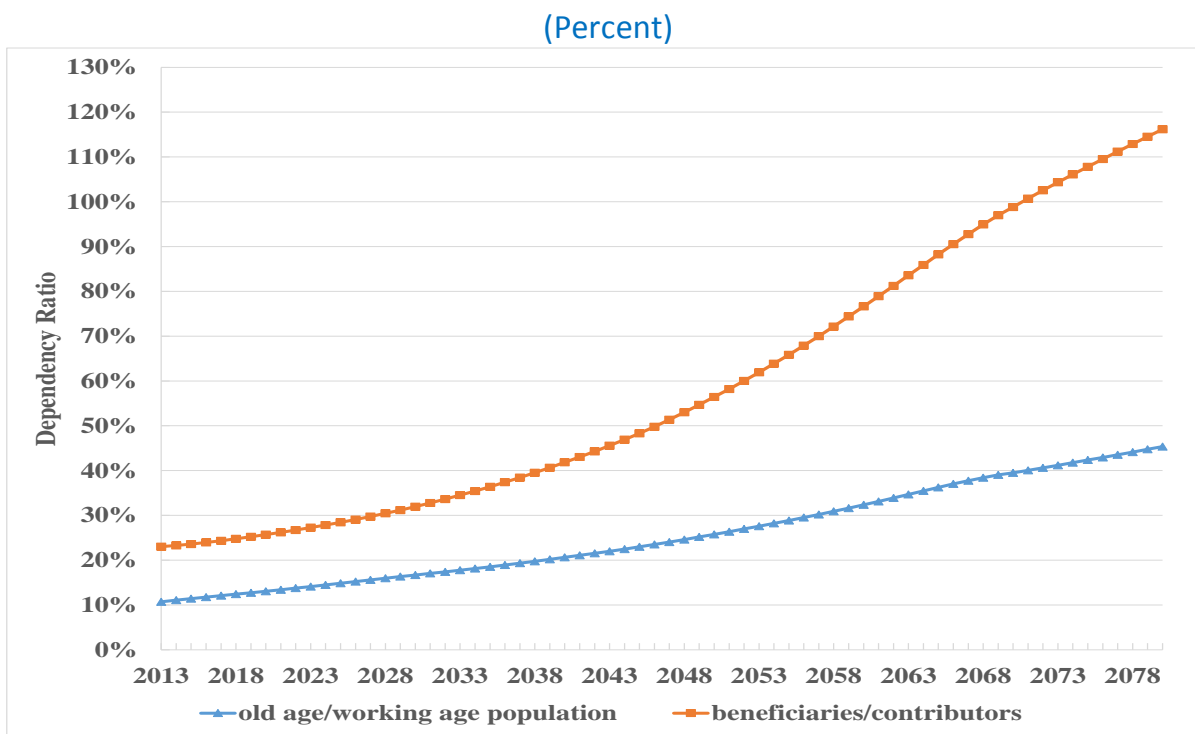

Source: World Bank estimates, UN World Population Prospects, the 2012 revision.

\section{Going forward, in about quarter of a century, increases in the SSS old age dependency ratio} along with flattening of the relative size of the working-age population will begin to have significant implications for pensions and social security policy. In general, pension schemes such as the SSS that are financed on a pay-as-you-go (PAYG) or partially funded basis will face increasing outflows due to increasing numbers of retirees. At the same time, they will face moderating inflows as the number of contributors will be limited by the delayed effects of declining fertility rates. At the household level, aging means that families will have to support more retired members with a smaller ratio of working household members to those too old to work.

\section{B. Labor Market}

9. The Philippine labor market is characterized by high levels of informality. ${ }^{4}$ The World Bank has estimated that around 75 percent of Filipino workers are informally employed. The National Statistics

\footnotetext{
${ }^{4}$ See World Bank, Philippine Development Report: Creating More and Better Jobs, September 2013, p. 72. The report defines informal workers as including self-employed workers (not including employers); unpaid family workers; and wage workers with no written contract, social insurance, or protection from dismissal. The data source was the 2008 Informal Sector Survey (ISS) 62 of the National Statistics Office (NSO). Administrative data on the population covered by SSS by firm size was not available. See also World Bank, Republic of the Philippines, Labor Market Review, Employment and Poverty, Report Number: AUS8661, January 22, 2016.
} 
Office (NSO) and the Department of Trade and Industry (DTI) estimate that around 90 percent of Filipinos work in micro, small, and medium-size enterprises (MSME) or as own-account workers. The NSO broadly defines the informal sector as those enterprises that fall outside the purview of government regulations. Operationally, the informal sector includes the agriculture and informal services sectors, the latter of which includes wholesale and retail trade, transportation, communication, and storage.

\section{Although wage and salaried workers account for about 55 percent of total employment,} many of these workers do not contribute to the SSS, and many do not receive adequate protection under the Labor Code. Only about 38 percent of wage workers indicate that they contribute to the SSS or GSIS. About 40 percent of wage workers have some level of protection from dismissal; about onethird get compensation in the case of dismissal; and about one-third get some form of paid leave, sick leave, and/or maternity/paternity leave (Table 1). The remaining workers are either own-account (33 percent) or unpaid workers in family micro-enterprises (12 percent) that generally have even lower levels of protection. Agricultural workers have the highest degree of informality, with more than 90 percent of workers experiencing low levels of protection and high levels of income insecurity.

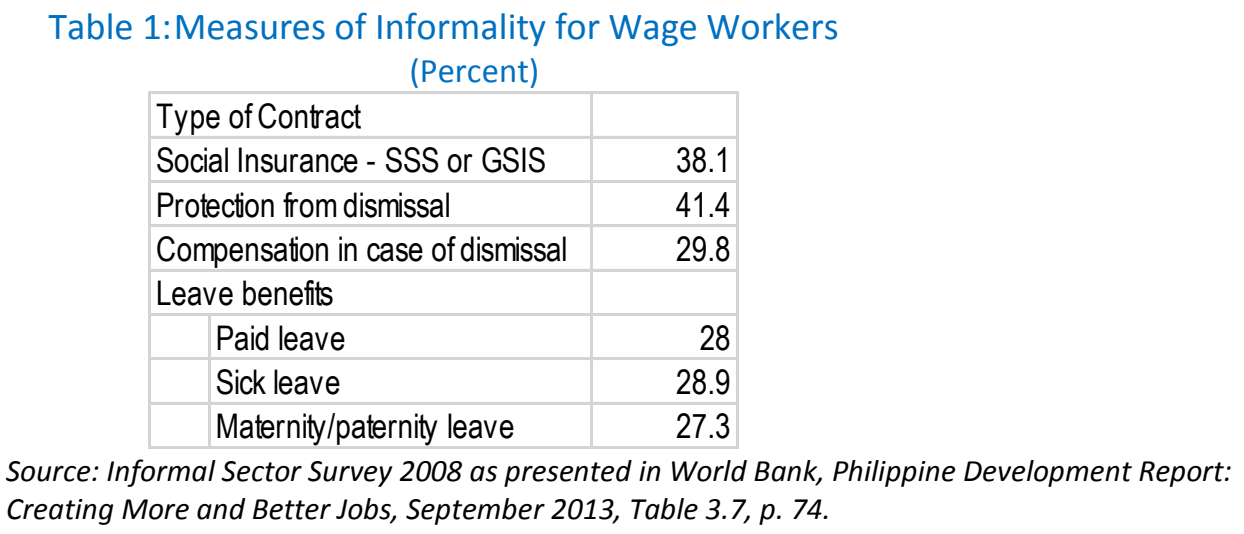

11. Such high levels of informality can be explained by both worker characteristics and the nature and composition of jobs. Barriers to employment generation include a weak investment climate and costly business, tax, and labor market regulations. Workers also have a limited skill set, in part due to the substantial outmigration of skilled workers. The result is that "the vast majority of workers have remained trapped in low-wage and low-productivity jobs in the informal sector, with limited opportunities to move up the job ladder." ${ }^{5}$

\section{The high level of informality and wage distribution have important implications for social} security participation. There are significant and understandable challenges in the enforcement of contribution compliance requirements in an environment characterized by high levels of informality. Weak enforcement leads many employers either not to participate or to selectively participate only for long-term workers. This is aligned with workers' interests to the extent that employees may also seek to avoid remitting employee contributions or may collaborate with employers to under-report wages. Moreover, very limited job security, low wages and other potential risks such as loss of health generally

\footnotetext{
${ }^{5}$ World Bank, Philippine Development Report: Creating More and Better Jobs, September 2013.
} 
leads workers to prefer immediate compensation rather than waiting until retirement ${ }^{6}$. Short-term risks such as loss of income or health, or investment in children's education may tend to be much higher priorities for workers than saving for retirement.

\section{Elderly Living Arrangements and Sources of Income ${ }^{7}$}

13. Living arrangements and sources of income are important to elderly vulnerability and poverty and thus have implications for the design of contributory pensions or non-contributory social

assistance. Elderly living with non-elderly potentially have access to the labor income of non-elderly, but they are similarly vulnerable if there is insufficient income or if the household falls into poverty. Such undiversifiable risk is one of the rationales for elderly assistance programs such as the Social Pension scheme in the Philippines.

14. Data on elderly living arrangements provides a strong rationale for using the household as the basis for targeting the Social Pension program. More than 80 percent of Filipino elderly live with nonelderly, although this ratio decreases somewhat as the elderly get older (Figure 2). The proportion of elderly as heads of household also decreases with age. At the same time, the proportion of elderly living alone and living only with elderly increases with age. This data underscores the rationale for using the household as the basis for targeting the Social Pension program. The national household targeting system - Listahanan is used to identify poor elderly who may qualify for the social pension program if they meet other program specific requirements based on a per-capita income estimates.

\footnotetext{
${ }^{6}$ In work poverty is pervasive in the Philippines. See World Bank, Philippines Labor Market Review, Employment and Poverty, January 22, 2016.

${ }^{7}$ This section was substantially limited by the absence of household survey data that indicates the sources of individual income tabulated by five-year cohorts. This analysis examined elderly employment data in an effort to get a fuller picture of their income sources and vulnerability.
} 
Figure 2: $\quad$ Elderly Living Arrangements

(Percent of total)

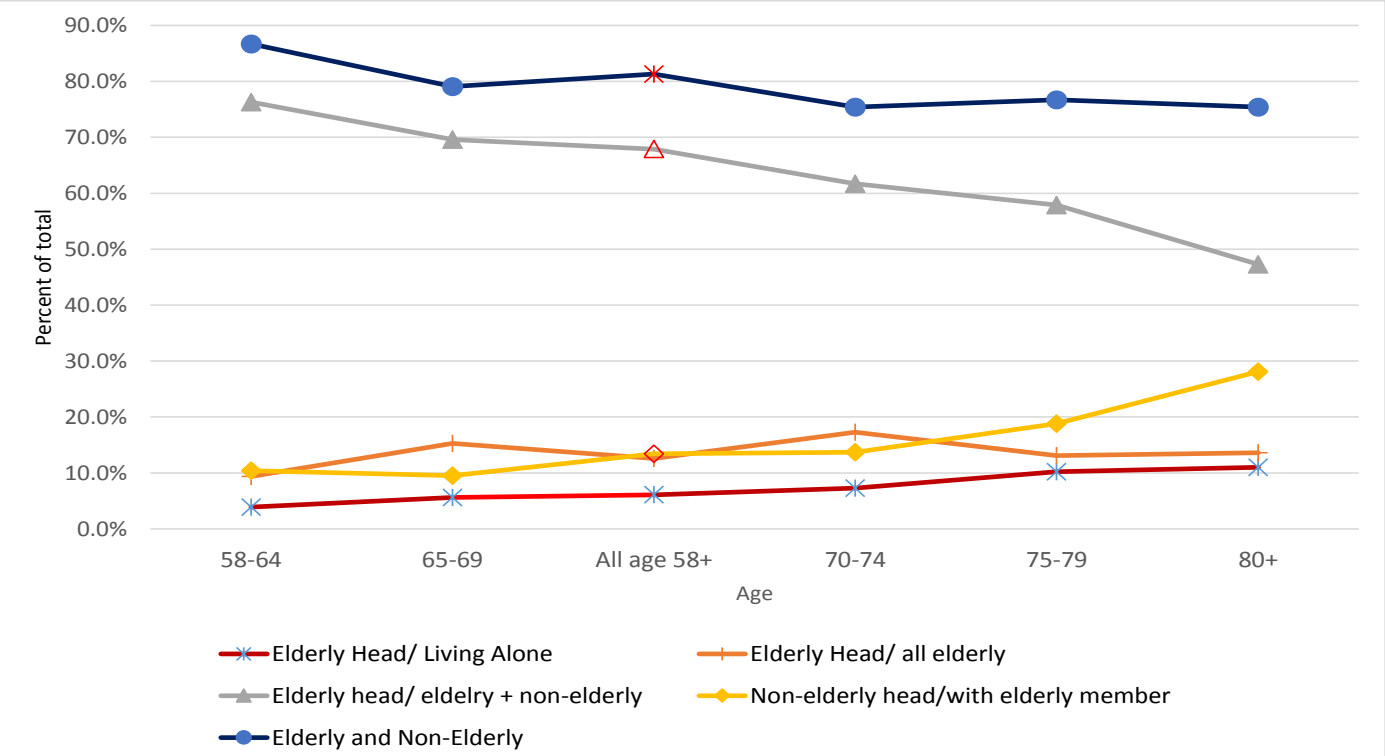

Source: 2007 Annual Poverty Indicators Survey (APIS), data cited in Racelis, Abrigo and Salas, Filipino Elderly Living Arrangements, Work Activity and Labor Income as Old-age Support, Table 2, p. 6.

Note: In this data, elderly refers to individuals age 58 and above. In other cases in this report, elderly refers to individuals age 60 and above.

15. In terms of income sources, labor force participation is noticeably high among the workingage population, particularly at higher ages, indicating the importance of labor income to households. Total labor force participation peaks during the ages of 45-54, although men are beginning to leave the labor force as women continue to increase their participation (Figure 3). By ages 55-64, total labor force participation remains at almost 70 percent. Although elderly Filipinos are employed less as they age, labor force participation remains high until they are unable to work. About one-third of workers ages 75-79 report to have worked.

Figure 3: $\quad$ Labor Force Participation by Age

(Percent)

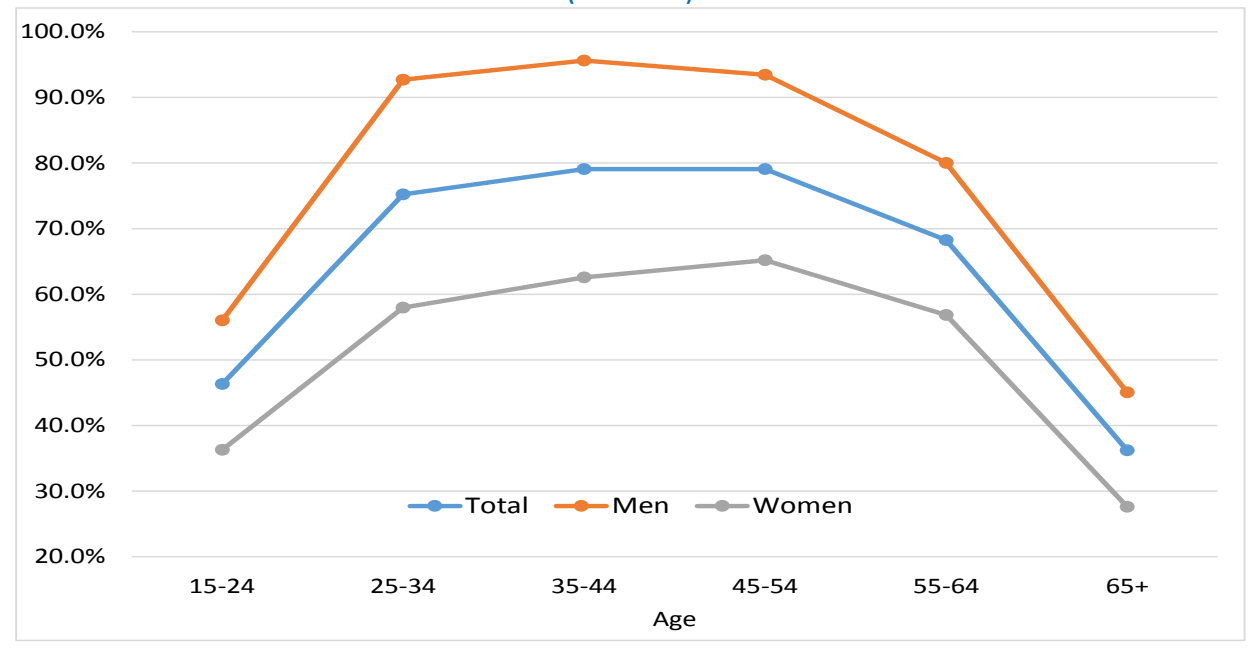

Source: April 2015 Labor Force Survey, Table 1B. 
16. The importance of self-employment and employment in family operations grows as Filipinos age. As Filipinos reach the legal retirement age of 65 , their relative employment in government and private enterprises declines substantially from about one-third to about 21 percent at ages 75-79, with further decline for older workers (Figure 4). Among older workers with employment income, selfemployment income grows from about 58 percent of the total for those ages 58-64 to over 75 percent for those age 80 and above. As indicated in Figure 4, the proportion of elderly that are employed understandably falls from 65 percent from ages 58-64 to only $15 \%$ at ages 80 and above as individuals lose the capacity to work.

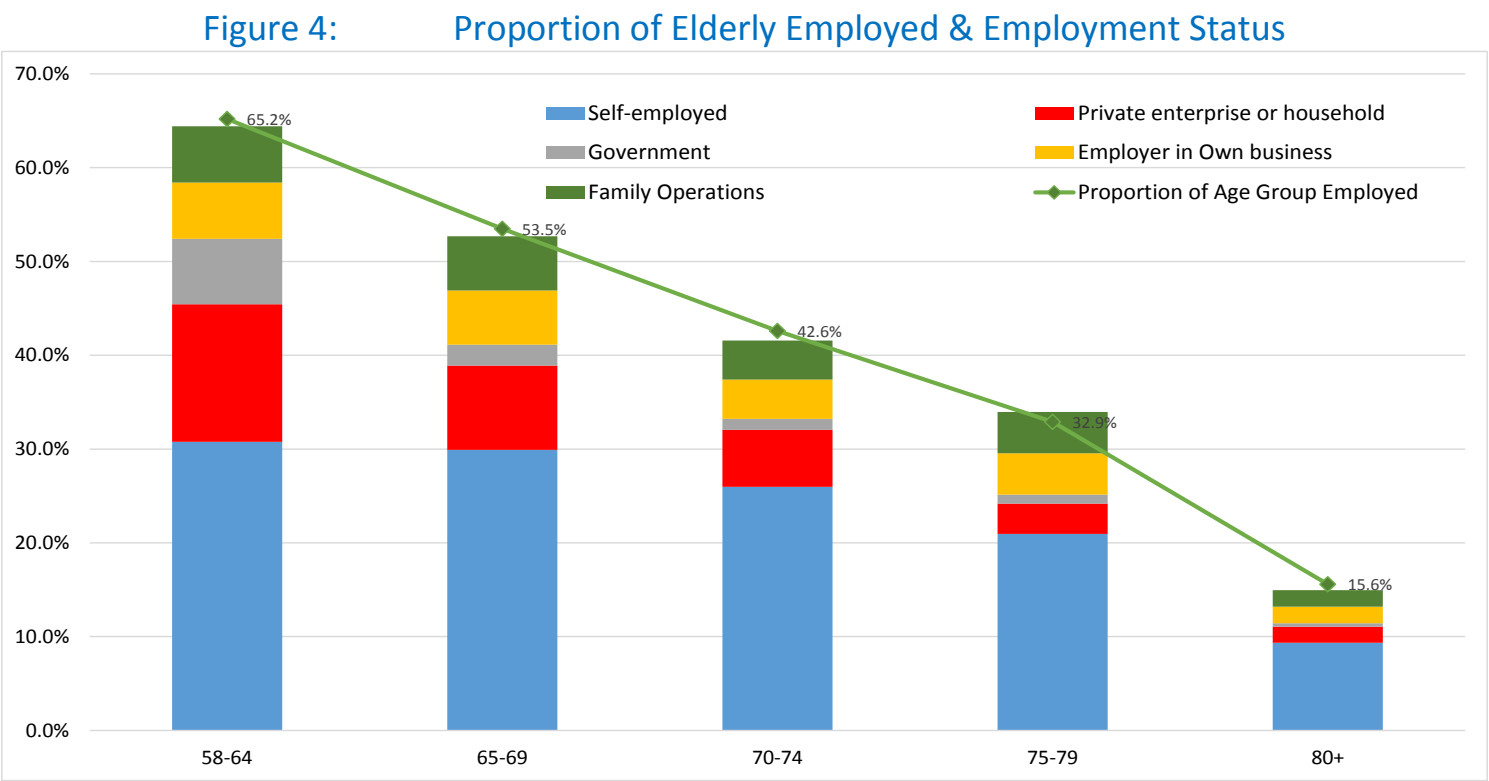

Source: 2007 Annual Poverty Indicators Survey (APIS), data cited in Racelis, Abrigo and Salas, Filipino Elderly Living Arrangements, Work Activity and Labor Income as Old-age Support, Table 8, p. 9.

17. As the elderly age and rely less on employment income, other income sources such as intrahousehold transfers and asset-based income take on substantial importance (Table 2). ${ }^{8}$ For those elderly living with non-elderly, asset-based income and transfers represent almost one-third of household income. Those elderly either living alone or with all elderly rely much less on labor income and much more on asset income than multi-generational households. Notably, pension income is not significant, accounting for only about 12-13 percent of total income for households comprised of all elderly and even less for those living with non-elderly.

\footnotetext{
${ }^{8}$ It is important to note that we did not have access to HHS data for transfers to individuals, including by cohort.
} 
Table 2: Elderly Sources of Income by Household Type

(Percent)

\begin{tabular}{|c|c|c|c|c|}
\hline & $\begin{array}{l}\text { Elderly head/one } \\
\text { person }\end{array}$ & $\begin{array}{l}\text { Elderly head/ all } \\
\text { elderly }\end{array}$ & $\begin{array}{c}\text { Elderly head/ with } \\
\text { elderly and non- } \\
\text { elderly }\end{array}$ & $\begin{array}{c}\text { Non-elderly head / } \\
\text { with elderly } \\
\text { member }\end{array}$ \\
\hline Labor income & 21.7 & 27.2 & 50.8 & 56.2 \\
\hline \multicolumn{5}{|l|}{ Transfers } \\
\hline Domestic & 9.1 & 6.0 & 2.9 & 2.0 \\
\hline International & 15.8 & 15.9 & 11.4 & 12.6 \\
\hline Pension & 13.2 & 12.5 & 6.5 & 3.0 \\
\hline Asset - income & 35.3 & 32.7 & 21.1 & 18.0 \\
\hline Asset - other & 2.7 & 2.7 & 3.9 & 3.2 \\
\hline Other & 2.2 & 3.0 & 3.4 & 5.0 \\
\hline Total & 100.0 & 100.0 & 100.0 & 100.0 \\
\hline
\end{tabular}

Source: APIS 2007 in R. Racelis, M. R. Abrigo, J.M. Salas, 2012. Filipino Elderly Living Arrangements, Work Activity, and Labor Income as Old-Age Support, Philippine Institute for Development Studies, Discussion Paper Series No. 2012-31, October 2012.

\section{Poverty and Inequality}

18. Poverty incidence in the working-age population provides some indication of the difficulty individuals have in contributing to payroll-tax based social security arrangements. As of mid-2014, about one-fifth of households and about one-quarter of individuals in the Philippines fell under the national poverty line. ${ }^{9}$ Rural and agricultural workers are particularly vulnerable to poverty and represent the bulk of the working poor as well as urban workers who have informal and low-skilled jobs who are vulnerable to poverty. ${ }^{10}$ Labor force status has little impact on the risk of poverty and indeed the majority of working age poor are employed. ${ }^{11}$ Workers in private households (such as domestic workers) and family-operated businesses or farms-who comprise relatively smaller proportions of the total population-have the highest poverty incidence (Figure 5). Understandably, the self-employed have higher risk of poverty when compared with wage workers in both rural and urban areas. ${ }^{12}$

\footnotetext{
${ }^{9}$ Philippines Statistical Authority, $1^{\text {st }}$ semester, 2014.

${ }^{10}$ See World Bank, 2016, Republic of the Philippines: Labor Market Review, p. 47.

11 Ibid, p. 48.

12 Ibid, p. 50-51.
} 
Figure 5: $\quad$ Poverty Headcount by Employer Type

(Percent)

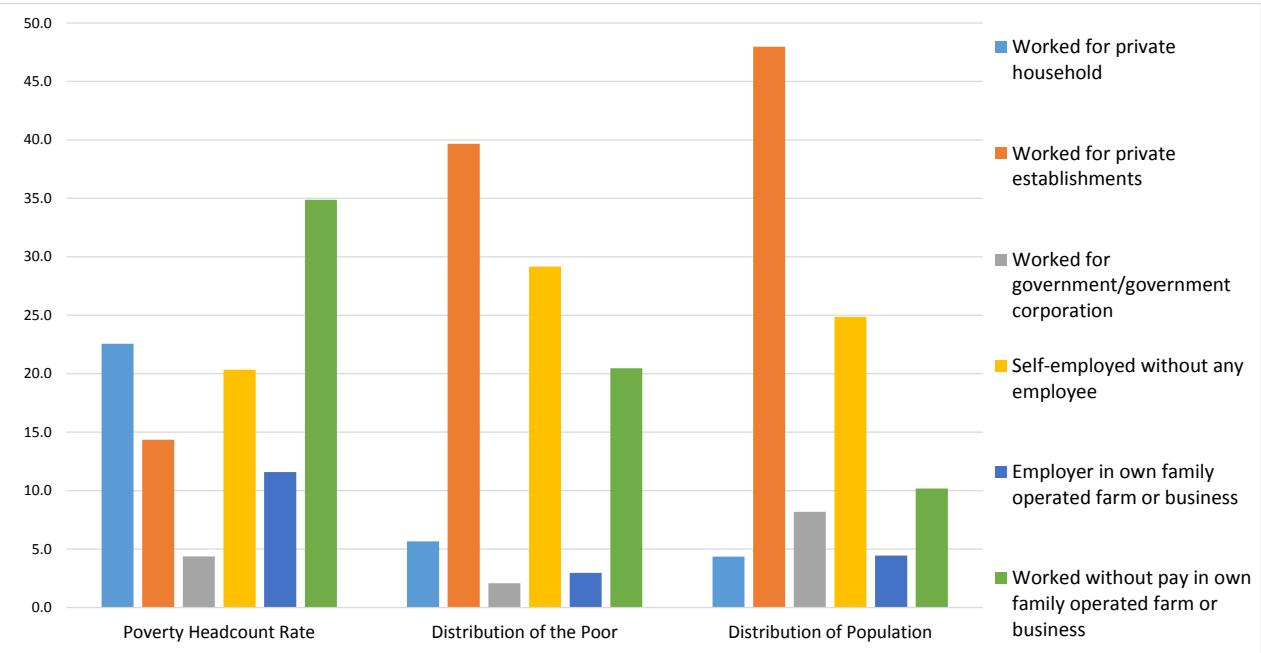

Source: Household Survey 2013, Poverty and Inequality Data.

19. Poverty incidence among the elderly was lower than for other age groups, possibly because of family support/living arrangements and accumulated assets. In 2013, poverty incidence among the elderly (11 percent) was significantly lower than the national average (over $25 \%$ ), lower than for the working-age population and was less than half that of children age 14 and under (29 percent) (Figure 6). ${ }^{13}$ This pattern, which is consistent with many countries worldwide, may be partly explained by many elderly having children to support them and some having accumulated assets in retirement. As of 2013, almost half of the poor in the Philippines were children, while only 5.7 percent of the total were elderly. From a policy perspective, this distribution of poverty suggests that scarce resources for transfers should consider poverty prevalence across lifecycle when using the age of recipients as an eligibility criteria.

Figure 6: $\quad$ Poverty Headcount Incidence and Share by Five-Year Cohorts

(Percent)

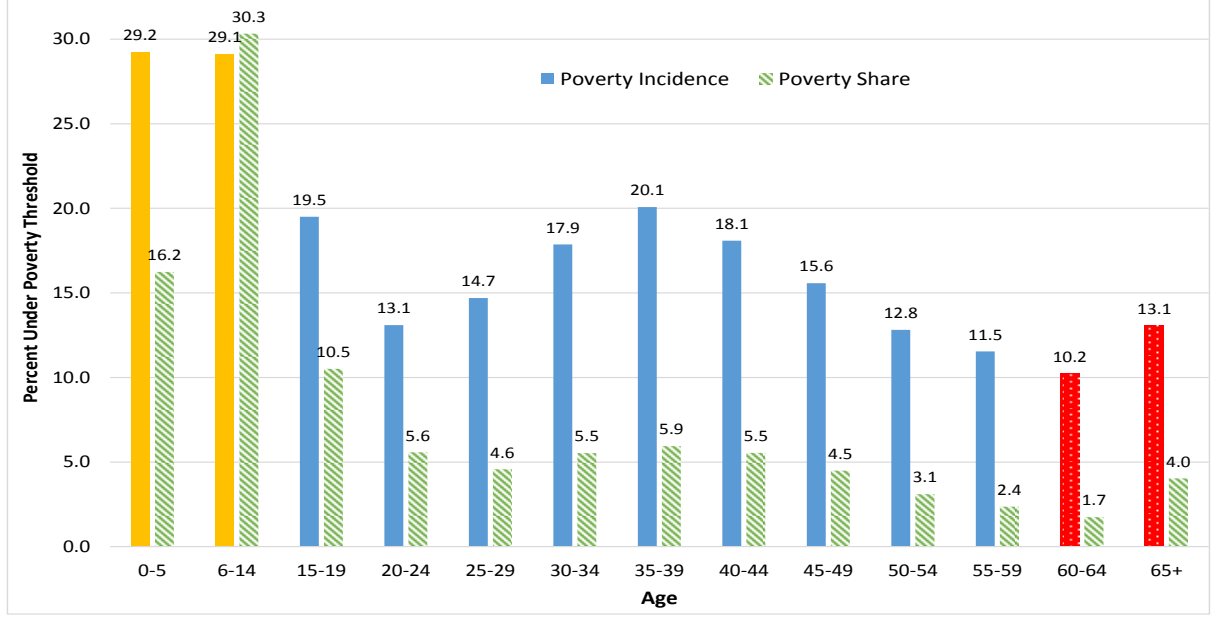

Source: Household Survey 2013, Poverty and Inequality Data.

\footnotetext{
${ }^{13}$ This calculation used the national poverty line, which represents the bottom 20 percent of the income distribution for the entire population.
} 
20. In addition to the challenge of poverty, the Philippines faces high levels of income and welfare inequality. The income Gini coefficient for the Philippines was 48.0 in 2012, one of the highest in the region. ${ }^{14}$ Almost half of the income was received by those in the top quintile, while those in the bottom quintile received about 6 percent (Figure 7).

Figure 7: $\quad$ Income Distribution by Quintile

(Share of total, percent, 2012)

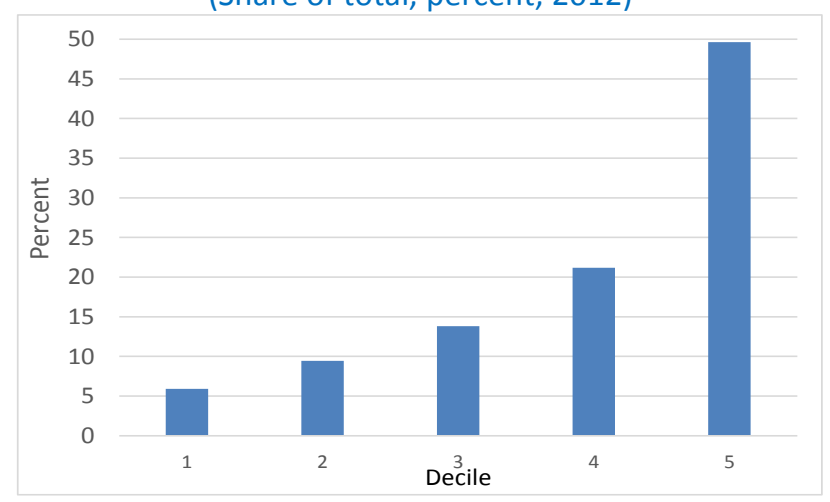

Source: World Development Indicators, 2015.

\section{E. Conclusions}

21. To conclude, the following were the major findings of this section: The Philippines has a relatively young demographic profile though the proportion of elderly is increasing. The labor market is characterized by high rates of informality for the Philippines per capita income level with such high levels attributed to worker characteristics and the nature and composition of jobs. About 80 percent of the elderly live in households with non-elderly, and often both contribute to the household and depend on other elderly and non-elderly household members when they cannot work. Understandably, employment by the elderly decreases as individuals get older. Poverty incidence among the elderly was lower than for the working age population and much lower than for children. There is also very high income inequality.

\section{Social Security and Pension Programs for Private Sector Workers}

\section{This section describes the SSS scheme, including its programs for informal workers, private} voluntary supplementary schemes, and the DSWD Social Pension. The discussion of supplementary schemes and the Social Pension has been limited to their importance as part of coverage expansion options. The section does not discuss the Government Service Insurance System (GSIS) or contributory Home Development Mutual Fund, also known as the Pag-IBIG Fund.

\section{A. Social Security System}

1. Description

\footnotetext{
${ }^{14}$ World Economic Indicators, accessed October 2015.
} 
23. The SSS is a defined-benefit scheme for private sector employees, including the self-employed. The scheme has three benefit formulas, essentially providing the best of: (i) 40 percent of the wage base for those with 10 years of contributions, (ii) PHP 300/month +20 percent of the wage base for 10 years and 2.0 percent per year of contributory service for each year thereafter, or (iii) PHP 1,200/month (Table 3). Annuitized benefits can be received after 10 years of contributions at age 60 for most workers, 55 for miners, and 65 for the self-employed. Age 65 is the mandatory retirement age. Indexation is discretionary based on the observed level of inflation and the financial position of the fund. The applicable minimum pension depends on the years of contribution, with a minimum benefit of PHP 1,200 /month after 10 years of contributory service and PHP 2,400/month after 20 years of contributory service. $^{15}$

24. The SSS is a partially funded scheme with mandatory contributions. Contribution rates are 7.4 percent for employers and 3.6 percent for employees, or 11.0 percent total for both. The self-employed pay the full 11.0 percent contribution. Although there is a minimum covered wage of PHP 1,000/month, this is waived for participants in the AlkanSSSya program for informal sector workers, described in greater detail below. ${ }^{16}$ The maximum covered wage is PHP $16,000 /$ month or about 100 percent of the average wage for covered workers.

\footnotetext{
${ }^{15}$ As stated in the Introduction, this report does not discuss disability, survivorship, and work injury benefits.

${ }^{16}$ The minimum covered wage ranges from about 200 to 400 percent of the legal minimum wage, which varies by region. See Department of Labor and Employment, National Wages and Productivity Commission, 2016, http://www.nwpc.dole.gov.ph/pages/statistics/latest_wo.html
} 
Table 3: $\quad$ Summary of Key Pension Parameters

\begin{tabular}{|c|c|c|c|}
\hline & SSS & GSIS & DSWD Social Pension \\
\hline $\begin{array}{l}\text { Contribution rates - } \\
\text { Total } \\
\text { Employer } \\
\text { Employee }\end{array}$ & $\begin{array}{l}11.0 \% \\
7.4 \% \\
3.6 \%\end{array}$ & $\begin{array}{l}21.0 \% \\
12.0 \% \text { (of which } 2 \% \text { for Life }^{17} \\
\text { Insurance) } \\
9.0 \% \text { (of which } 2 \% \text { for Life } \\
\text { Insurance) }\end{array}$ & Non-contributory \\
\hline $\begin{array}{l}\text { Minimum salary subject } \\
\text { to contributions (per } \\
\text { month) }\end{array}$ & PHP 1,000/month & Minimum wage & \\
\hline $\begin{array}{l}\text { Maximum salary } \\
\text { subject to contributions }\end{array}$ & PHP 16,000/month (2015) & None & \\
\hline \multicolumn{3}{|l|}{ Qualifying conditions } & $\begin{array}{l}\text { - Household must be identified as } \\
\text { poor by the national household } \\
\text { targeting system - Listahanan } \\
\text { - Senior citizens who are frail, sickly, } \\
\text { or have disability; do not receive } \\
\text { pensions from SSS, GSIS, or } \\
\text { Veterans Pension; and have no } \\
\text { permanent source of income or } \\
\text { regular support from relatives }\end{array}$ \\
\hline $\begin{array}{l}\text { Minimum vesting } \\
\text { period }\end{array}$ & 10 years contributory service & 15 years contributory service & None \\
\hline $\begin{array}{l}\text { Minimum retirement } \\
\text { (benefit eligibility) age }\end{array}$ & $\begin{array}{l}60 \text { - } 65 \text { (mandatory age); } 55 \text { for } \\
\text { miners }\end{array}$ & $\begin{array}{l}60 \text { - } 65 \text { (mandatory age) unless } \\
\text { not yet vested }\end{array}$ & $\begin{array}{l}65-1 / 1 / 2015 ; 60 \text { proposed } \\
1 / 1 / 2016 ; 60\end{array}$ \\
\hline $\begin{array}{l}\text { Actuarial adjustments } \\
\text { for early retirement }\end{array}$ & $\begin{array}{l}\text { None prior to age } 65 \text { or age } 60 \text {; } \\
\text { virtually no retirement before } \\
\text { age } 60 \text { permitted except for } \\
\text { miners at age } 55\end{array}$ & None & \\
\hline \multicolumn{4}{|l|}{ Benefits - old age } \\
\hline Old age - benefits & $\begin{array}{l}\text { Highest of three options: 1) PHP } \\
300 \text { monthly }+20 \% \text { of Average } \\
\text { Monthly Salary Credit (AMSC) } \\
\text { for each calendar year of service } \\
\text { (CYS) }+2 \% \text { for each CYS } \\
\text { exceeding } 10 \text { years, 2) } 40 \% \text { of } \\
\text { AMSC, or } 3 \text { ) PHP } 1,200 \text { monthly }\end{array}$ & $\begin{array}{l}2.5 \% * \text { [PHP } 700+\text { Average } \\
\text { Monthly Compensation (AMC)] } \\
2 \text { options: 1) lump sum equal to } \\
\text { Basic Monthly Pension (BMP) * } \\
18, \text { plus BMP for life; and } 2 \text { ) } \\
\text { lump sum equal to BMP * } 60 \\
\text { plus BMP for life after } 5 \text { years }\end{array}$ & PHP 500/month \\
\hline $\begin{array}{l}\text { Those not meeting the } \\
\text { vesting requirements - } \\
\text { Old Age Grant }\end{array}$ & $\begin{array}{l}\text { Accumulated contributions }+6 \% \\
\text { interest/year }\end{array}$ & & \\
\hline Minimum pension & $\begin{array}{l}\text { PHP } 1,200 \text { a month with } \\
\text { contribution period between } \\
10-20 \text { years and PHP } 2,400 \text { for } \\
\text { more than } 20 \text { years of } \\
\text { contribution }\end{array}$ & & \\
\hline Maximum benefit & None & $\begin{array}{l}90 \% \text { of average monthly } \\
\text { compensation in last } 3 \text { years }\end{array}$ & \\
\hline $\begin{array}{l}\text { Salary base (for pension } \\
\text { calculation) }\end{array}$ & $\begin{array}{l}\text { Highest salary in last } 5 \text { years or } \\
\text { average of last } 6 \text { months, not } \\
\text { revalued }\end{array}$ & $\begin{array}{l}\text { Last } 3 \text { years average salary, not } \\
\text { revalued }\end{array}$ & \\
\hline Indexation & $\begin{array}{l}\text { Ad hoc, as approved by SS } \\
\text { Commission ( } 60 \% \text { of inflation } \\
\text { over past } 20 \text { years) }\end{array}$ & $\begin{array}{l}\text { Ad hoc, as recommended by } \\
\text { Actuary \& approved by Board }\end{array}$ & $\begin{array}{l}\text { According to periodic revision } \\
\text { by the Congress }\end{array}$ \\
\hline
\end{tabular}

Sources: World Bank estimates; Mesa-Lago, Viajar and Castillo, 2009. Pensions in the Philippines Challenges and Ways Forward. Note: The presentation of GSIS parameters is for comparative purposes only.

\footnotetext{
${ }^{17}$ In addition, 1.0 percent of wages are contributed to an Employees Compensation Fund, up to a limit.
} 


\section{Coverage}

25. Although de-jure worker participation in the pension schemes is mandatory, actual or defacto coverage rates are low. The legal requirement for participation extends to all workers including self-employed, temporary, and informal sector workers. However, although there are over $\mathbf{3 0}$ million accounts with the SSS, only about 25 percent of the employed contribute on an active basis (Table 4). ${ }^{13}$ In 2013, about 17.8 percent of the working-age population and 25.8 percent of the labor force had contributed more than a month to either the SSS or GSIS. This level of worker coverage is roughly consistent with that of countries at a similar level of per capita GDP (Figure 8). ${ }^{18} \mathrm{~A}$ key reason for the strong correlation between worker coverage and per capita income is that the proportion of wagebased income tends to be higher in countries with higher levels of per capita income.

Table 4: Pension Coverage

(2013)

\begin{tabular}{|c|c|c|c|c|c|c|}
\hline & $\begin{array}{c}\frac{\text { Contributors }}{(' 000)} \\
\end{array}$ & $\frac{\frac{\text { Old Age }}{\text { Retirees }}}{\text { ('000) }}$ & $\frac{\frac{\text { Percent }}{\text { of Labor }}}{\text { Force }}$ & $\frac{\frac{\text { Percent of }}{\text { Working }}}{\text { Age }}$ & $\frac{\text { Percent of }}{\underline{60+}}$ & $\frac{\text { Percent }}{\text { of } 65+}$ \\
\hline SSS Registered & 30,721 & & 73.4 & 50.6 & & \\
\hline SSS Active contributors & 7,243 & & 17.3 & 11.9 & & \\
\hline SSS Self-employed & 2,106 & & 5.0 & 3.5 & & \\
\hline SSS Total & 9,349 & 1,043 & 22.3 & 15.4 & 14.2 & \\
\hline GSIS & 1,439 & 241 & 3.4 & 2.4 & 3.3 & \\
\hline \multicolumn{7}{|l|}{ Occupational } \\
\hline DSWD Social Pension & & 940 & & & 12.8 & 20.4 \\
\hline GSIS \& SSS & 10,787 & 1,284 & 25.8 & 17.8 & 17.5 & \\
\hline Philhealth & 31,267 & & 74.7 & 51.5 & & \\
\hline Govt Health & 2,073 & & 5.0 & 3.4 & & \\
\hline
\end{tabular}

Sources: World Bank estimates, SSS "Facts and Figures", Labor Force Survey 2014, UN Population Projections, 2015 revision.

Note: The covered population for SSS only includes "active" workers who contribute more than one month per year.

\footnotetext{
${ }^{13}$ Active contributors are defined as those who have contributed at least one month in the past 12 months. It is possible that inactive members may have more than one account. We have no way of identifying multiple accounts which could be associated with individual members. It should be noted that these "de facto" coverage rates are only a fraction of the "de-jure" coverage which is close to all workers engaged in economic activity. ${ }^{14}$ The data point in the figure refers to worker coverage for both the SSS and GSIS combined.
} 
Figure 8: $\quad$ Correlation between Global Coverage and GDP Per Capita

(Contributors as a percent of the working-age population in 2012 / GDP per capita - log scale)

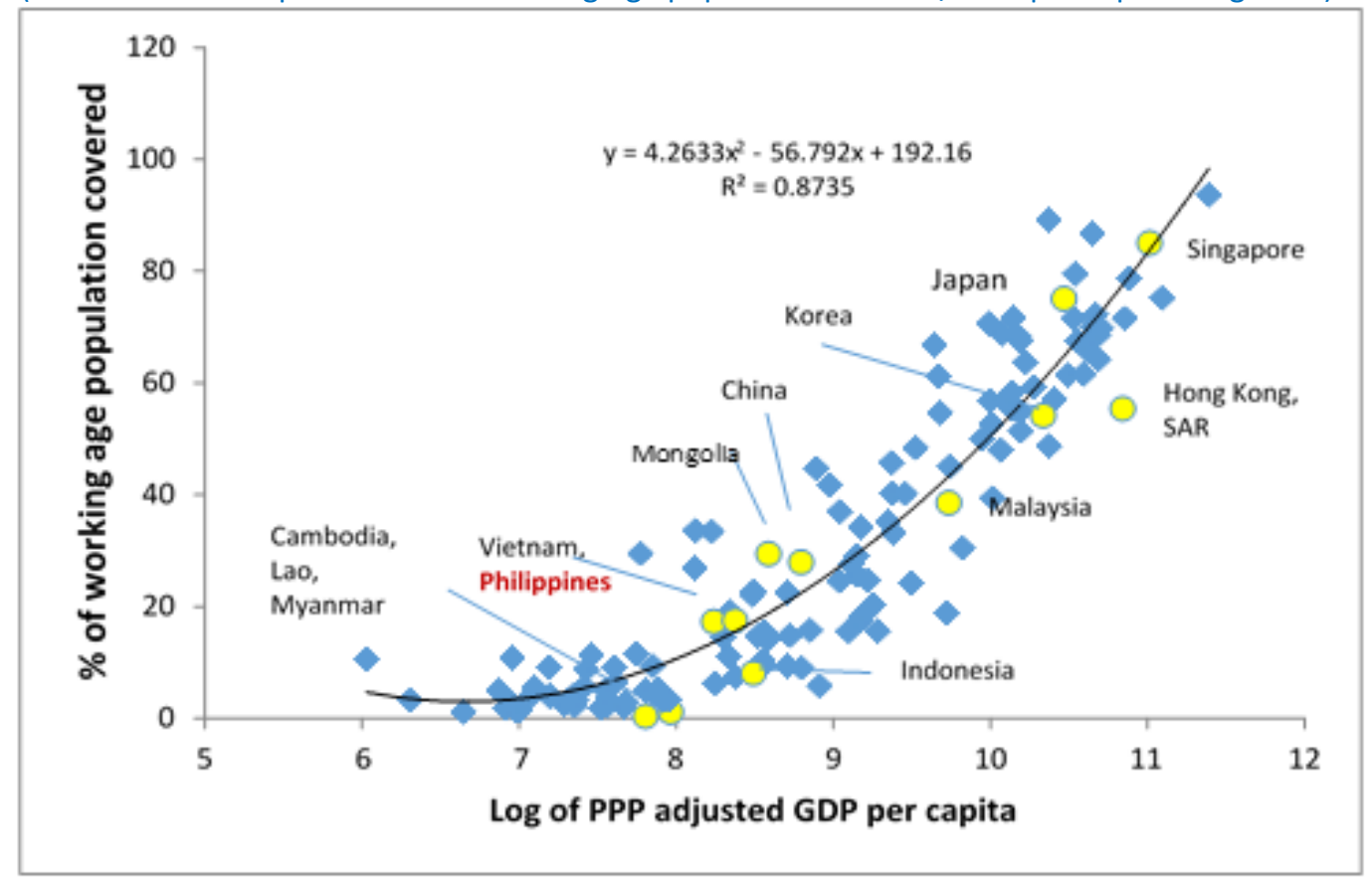

Source: World Bank pension database; www. worldbank.ora/pensions

26. The average density of SSS contributions in the Philippines is relatively low, suggesting that many workers are not participating for a substantial portion of their work lives. The average contribution density at retirement - measured as a proportion of a full work life from youth through retirement age - was about 26.5 in 2013. Such relatively low contribution densities, weaken individual replacement rates, affecting the adequacy of benefits.

27. In terms of beneficiary coverage, only 14.2 percent of those age 60 and above receive an old age pension from the SSS. One reason for the lower coverage rate of the elderly compared to the working population is that many older workers reach retirement age with insufficient years of contributory service to qualify for annuitized benefits. Very high levels of co-residency suggest that most of those without pensions will be covered by other means including intra-household transfers, remittances, and earnings from assets as discussed earlier.

\section{The SSS has made substantial efforts to increase coverage by expanding the scope of} employers and workers required to contribute. With respect to legal coverage, by 1960, all employers with at least one employee were required to contribute. ${ }^{19}$ The self-employed were required to contribute beginning in 1980, with self-employed professions then expanding to farmers, fisherman, and others in the 1990s. However, the actual implementation of the legal mandate for coverage has been costly and difficult to enforce, largely due, as discussed above, to the labor market situation of workers in the Philippines (prevailing informality and non-contract, intermittent employment).

${ }^{19}$ See C. Mesa-Lago, V. Viajar and R. Castillo, Pensions in the Philippines: Challenges and Ways Forward, p. 28. 
29. SSS member applications are accepted from self-employed people such as entrepreneurs, freelancers, and informal sector workers, as well as overseas Filipino workers (OFWs) and nonworking spouses of active members. Those eligible for voluntary SSS membership, such as OFWs and non-working spouses of active SSS members, can apply for their own SSS number through the SSS website. The SSS number issued can be converted from temporary to permanent status by presenting any accepted supporting documents, such as a birth or baptismal certificate or valid passport.

\section{The SSS also initiated measures several years ago to make it easier for informal sector} workers, the self-employed, and voluntary contributors to contribute. According to Mesa-Lago (2011), a system of Automatic Debt Arrangements was put in place to support informal worker contributions through accredited banks through automatic account deductions or over-the-counter transactions. ${ }^{20}$ Minimum deposit requirements were lowered for savings accounts at such accredited banks. Unfortunately, participation in these arrangements was very limited. The SSS also began to accredit cooperatives as collection agents for self-employed and voluntary contributors in 2011.

31. In 2012, the SSS launched the AlkanSSSya program with the aim of broadening the actual coverage to include the self-employed and informal sector. The program targets low- and limitedincome workers such as tricycle drivers, farmers, market vendors, fishermen, and other self-employed individuals. ${ }^{21}$ It aims to establish a piggy bank-like savings program in which the daily discipline of contributing at least PHP 10 could, over time, support a meaningful level of social security benefits. After three months of contributions, members are entitled to sickness, maternity, or funeral benefits. Educational loans are available after 12 months of contributions, disability loans after 36 months, and a pension claim after 10 years (at retirement age).

32. The SSS has partnered with informal sector groups (ISGs) and worker associations to facilitate collections and to market the AlkanSSSya program. Associations such as the association of tricycle drivers have helped serve as channels for worker registration, collections, and information disclosure. The SSS has also established a system of savings bank boxes at various locations where workers can deposit their daily contributions. At the end of 2014, the SSS had an estimated more than 122,000 members participating through over 1,200 ISGs. ${ }^{22}$

33. There are also severance arrangements and voluntary occupational and personal pension provisions operating outside of the scope of the SSS which could contribute towards coverage expansion and supplementary benefits (See Box 1). Although the tax advantages which will be available for Personal Equity and Retirement Account (PERA) are unlikely to be a meaningful incentive for informal workers (many of whom do not pay personal income taxes), such accounts can provide a meaningful supplement for middle-class self-employed and other workers.

\footnotetext{
${ }^{20}$ See C. Mesa-Lago et al., p. 38.

${ }^{21}$ See Meißner, Matthias, Old age protection for informal workers-feasible or too far away? March, 2014.

${ }^{22}$ See SSS, 2014 Annual Report, p. 13.
} 


\section{Box 1: Severance and Voluntary Occupational and Personal Pensions Arrangements}

Mandatory benefits provided by employers at retirement are established by law but such laws are generally not enforced. The Mandatory Retirement Pay Law of 1992 stipulates that all private sector employees are entitled to a payment at retirement (optional at ages 60-64 and mandatory at age 65) equivalent to a half month of salary for each year of service. This benefit is provided by the employer and is in addition to benefits provided by the SSS.

Voluntary occupational and personal pension plans are offered by "pre-need" and life insurance companies as well as can be directly provided by employers. "Pre-need companies" are authorized by the Insurance Commission to provide plans that are contracts providing for future payments. These pre-need pension plans have been in place since 1977. Pre-need plans often have a combination of endowment insurance and deferred annuities with life insurance policies in the event of death before retirement. Pre-need plans have also been available for other life events such as college savings. In August 2015, 12 out of 16 licensed pre-need companies offered pension plans. ${ }^{19}$ Insurance companies are also authorized to offer endowment and annuity contracts, which are considered life insurance contracts under the Philippine Insurance Code.

In 2008, the Personal Equity and Retirement Account (PERA) law established a common framework for taxfree private pension schemes. The authorities have since been putting in place operational, regulatory, and supervisory infrastructure to support the schemes. Although the schemes were supposed to begin operations in 2015, at the time of this writing, it seems that the authorization of providers or initial offering of the scheme has not yet taken place. The PERA will offer considerable tax advantages for participation, including a 5-percent tax credit for contributions up to PHP 100,000 yearly (PHP 200,000 for OFWs), tax exemption on fund accumulations, and tax-free withdrawals at age 55 and above (after contributing for at least five years). In the case of death, PERA assets are to be distributed to heirs tax-free (even if it happens before turning age 55).

34. To summarize, coverage and contribution densities are low in large part due to limited steady wage-based sources of income for many Filipino workers. Payroll-based contributory social security schemes tend to be most effective in covering individuals with steady wage incomes, however, most Filipino workers have intermittent work, often work in small companies or agriculture, or are selfemployed or single proprietors. The SSS has made substantial efforts to increase coverage by expanding the scope of employers and workers required to contribute. The SSS also initiated measures several years ago to make it easier for informal sector workers, the self-employed, and voluntary contributors to contribute. Automatic Debt Arrangements were put in place to support informal worker contributions through accredited banks through automatic account deductions. Moreover, the SSS launched the AlkanSSSya program with the aim of broadening the coverage of the self-employed and informal sector.

\section{Sustainability}

35. Baseline projections of SSS system finances using the Pension Reform Options Simulation Toolkit (PROST) suggest that the SSS faces a challenge to achieve long-term sustainability, albeit some time to adopt parametric reforms to address the challenge. Financial surpluses are projected for roughly the next 20 years, after which time projected deficits would eliminate fund assets about eight years later (Figure 9). ${ }^{23}$ The projected fund life for the SSS is therefore about 28 years extending to

\footnotetext{
${ }^{23}$ These projected estimates are based on several assumptions such as anticipated coverage levels, growth in real wages, and real returns on investment assets. Actual outcomes will likely differ from the projections to the degree
} 
about $2044 .{ }^{24}$ Projected system finances deteriorate over time, as the SSS system old age dependency ratios increase, leading to payouts in excess of revenues of over 1.0 percent of GDP by about 2060. The baseline projections produced similar results as the SSS 2011 Actuarial Assessment thereby effectively providing an external validation of the SSS actuarial results. ${ }^{25}$

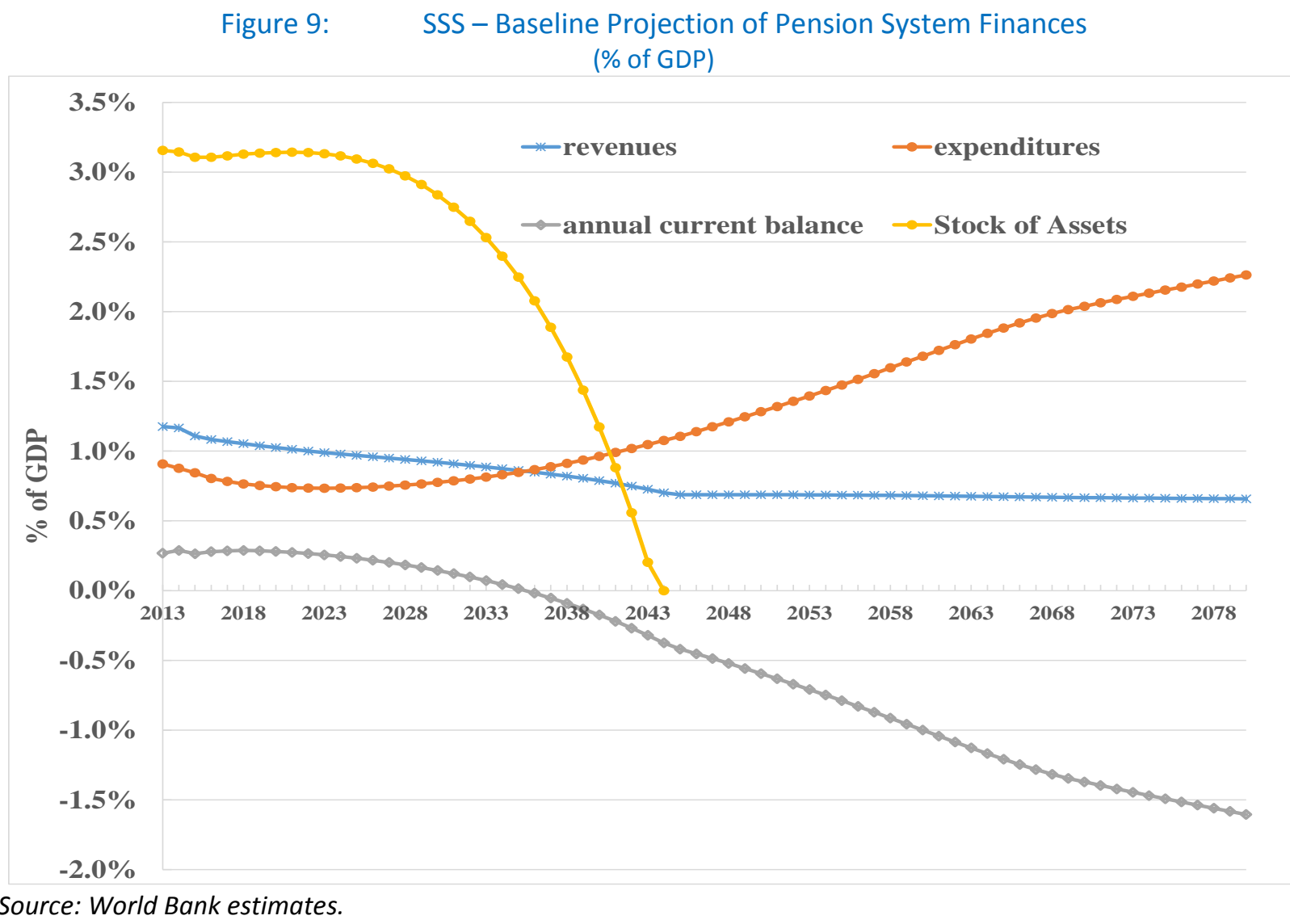

36. Much of the projected deterioration in the sustainability of the SSS stems from an aging profile of contributors and retirees along with a benefit formula and qualifying conditions that over time cannot be fully supported by contribution levels. An important driver is the projected number of contributors and retirees (Figure 10). The SSS is a maturing scheme, with many of its initial participants having reached or reaching retirement. The relative growth of the retiree and beneficiary populations will become more rapid during the projection period, resulting in growing system dependency ratios.

that the underlying assumptions differ from actual experience. Appendix 3 provides sensitivity analysis to illustrate the impact of alternative assumptions.

${ }^{24}$ The fund balance is defined as: (contributions + investment income) - (benefits paid + other expenses). The fund life is defined as the number of continuous years during which projected fund assets are positive.

${ }^{25}$ The PROST projections were made using end-2013 SSS administrative data. Although the projections were prepared in consultation with SSS staff, the Bank validated the major model assumptions. Staff compared the projections and isolated the reasons for the (minor) differences in results between the PROST baseline projection on the one hand, and the SSS 2011 Actuarial Assessment, on the other. The fund life termination of 2044 compares with the SSS Actuarial Assessment projection of 2042. The differences are immaterial for a long-term actuarial assessment and can be attributed to several factors including differences in the base year used in the projections, inflation assumptions, applicable contribution rates, and the cap on covered wages assumed. 
These increasing system dependency ratios result in projected benefit payments that over time are higher than contributions and investment returns.

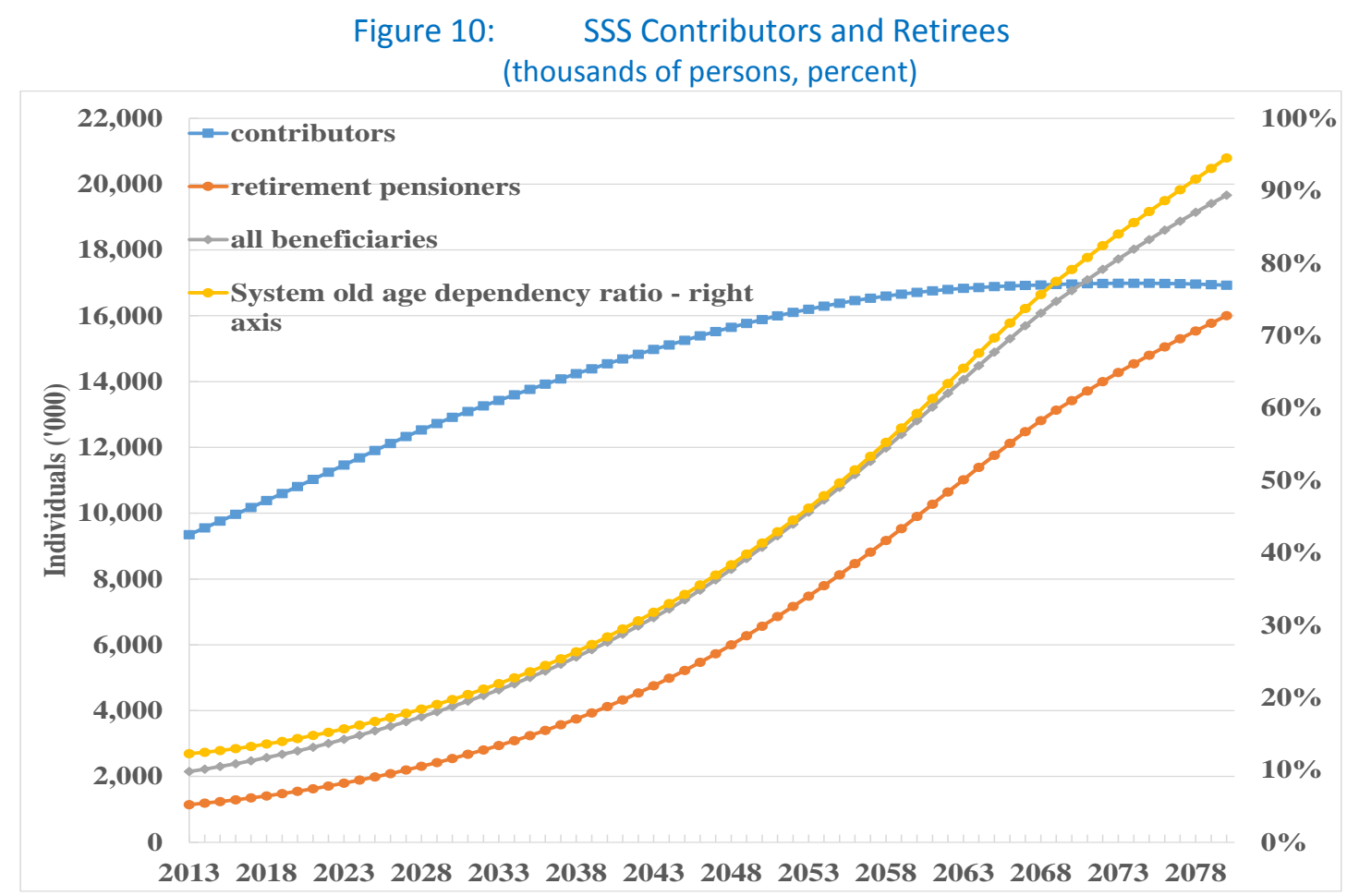

Source: World Bank estimates.

\section{On the other hand, the baseline projections also suggest that the Philippines can enact a} gradual program of parametric reforms that can strengthen sustainability while at the same time avoiding abrupt changes to benefits, eligibility conditions or contribution rates. As discussed below, a gradual approach to implementing parametric reforms can achieve sustainability while preserving acquired rights. A comparison of selected countries in the East Asia and Pacific (EAP) region shows that public schemes in other countries face sustainability challenges, as well, albeit generally in a more pronounced form that the Philippine's case (Table 5). ${ }^{26}$

\footnotetext{
${ }^{26}$ The comparison should be read with caution, because there is no common framework for benchmarking sustainability across countries. Such a framework would require a common projection methodology, including a framework for long-term assumptions for key variables, which is currently not available.
} 
Table 5: Indicators of Sustainability of Public Defined Benefit Schemes in Selected Countries

\begin{tabular}{|l|c|c|c|}
\hline \multicolumn{1}{|c|}{ Country/year } & Source & Year reserves exhausted & $\begin{array}{c}\text { Deficit/surplus in 2040 as } \\
\text { percent of GDP* }\end{array}$ \\
\hline Philippines (2015) & World Bank (2016) & 2044 & -0.2 \\
\hline China (2010) & Herd et al. (2010); & Ma et al. (2012) & -3.5 \\
& Japan & N.A. & -3.3 \\
\hline Japan (2009) & Korea NPS & 2060 & -1.4 \\
\hline Korea (2013) & World Bank (2012) & No reserves & -4.5 \\
\hline Mongolia (2011) & ILO & 2051 & Negative from 2041 \\
\hline Thailand & ILO & 2034 & -1.7 \\
\hline Vietnam (2012) & & \\
\hline
\end{tabular}

Source: Bank estimates, Robert J. Palacios. Pensions in Aging East Asia, Draft Mimeo, World Bank, November 2014; ILO; World Bank; Mesa-Lago et al. (2011); Herd et al. (2010). Ma et al. (2012).

* Refers to cash flow deficits, i.e. current contributions minus current benefits. Thailand and Philippines exclude civil servants.

\section{Adequacy and Equity}

38. Examining replacement rates for full-term workers, the Philippines was found to promise a benefit from the SSS comparable to several other countries in the EAP region. OECD estimates of fullterm replacement rates suggest that the Philippines has a gross replacement rate of about 38 percent, just below the ILO target of 40 percent and below the OECD average of about 54 percent (Figure 11). ${ }^{27}$ A comparison with other EAP countries shows that replacement rates in the Philippines for middle- and low-income covered workers are higher than in several countries but lower than in China and Vietnam which have distinct socialist histories leading to higher replacement rates.

Figure 11: $\quad$ Select EAP Replacement Rates

(Percent of individual wage)

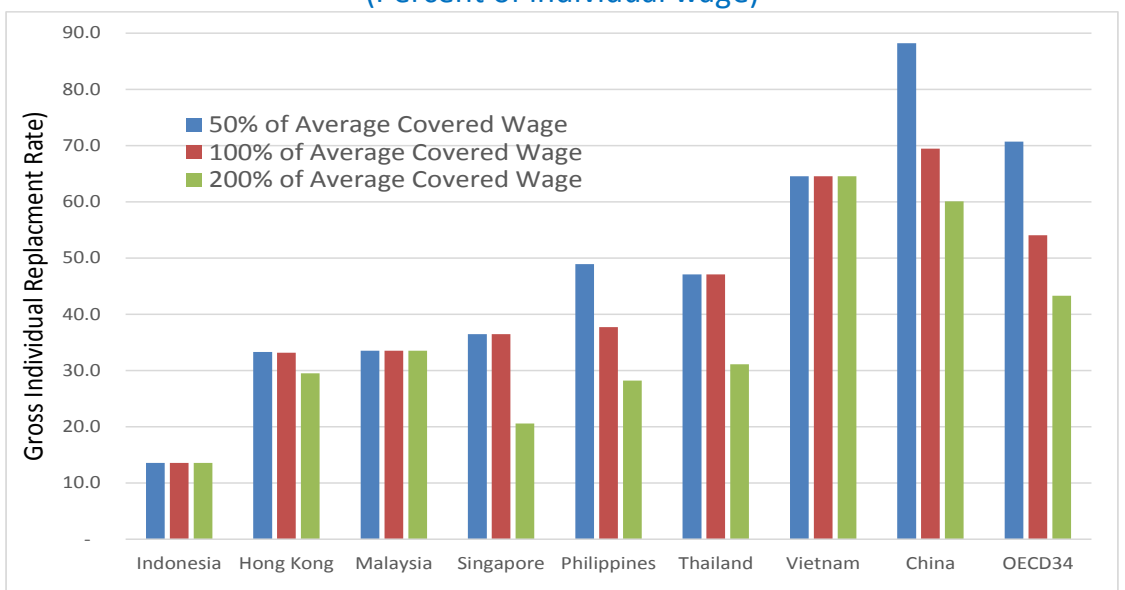

Source: OECD: Pensions at a Glance Asia Pacific, 2013.

Note: This applies for a full-term male worker.

39. Discretionary indexation of SSS benefits has failed to keep up with inflation over the past two decades, affecting adequacy. Indexation on average covered only about 60 percent of growth in the consumer price index (CPI) over the past two decades. Moreover, there were substantial multi-year lags between the adoption of indexation adjustments.

${ }^{27}$ ILO Convention 102 of 1952 establishes a 40 percent replacement rate target for individual workers. 


\section{In terms of equity, the distribution of pension income is concentrated in higher-income}

households (Figure 12). Almost half of the share of contributory pension benefits goes to those in the top decile of the income distribution, and almost 80 percent of the share goes to those in the top three deciles. Not only is the share of pensions concentrated in the upper deciles, but pension income as a proportion of household income also is highest in the upper deciles, with pension income representing almost 5 percent of total income for the top decile.

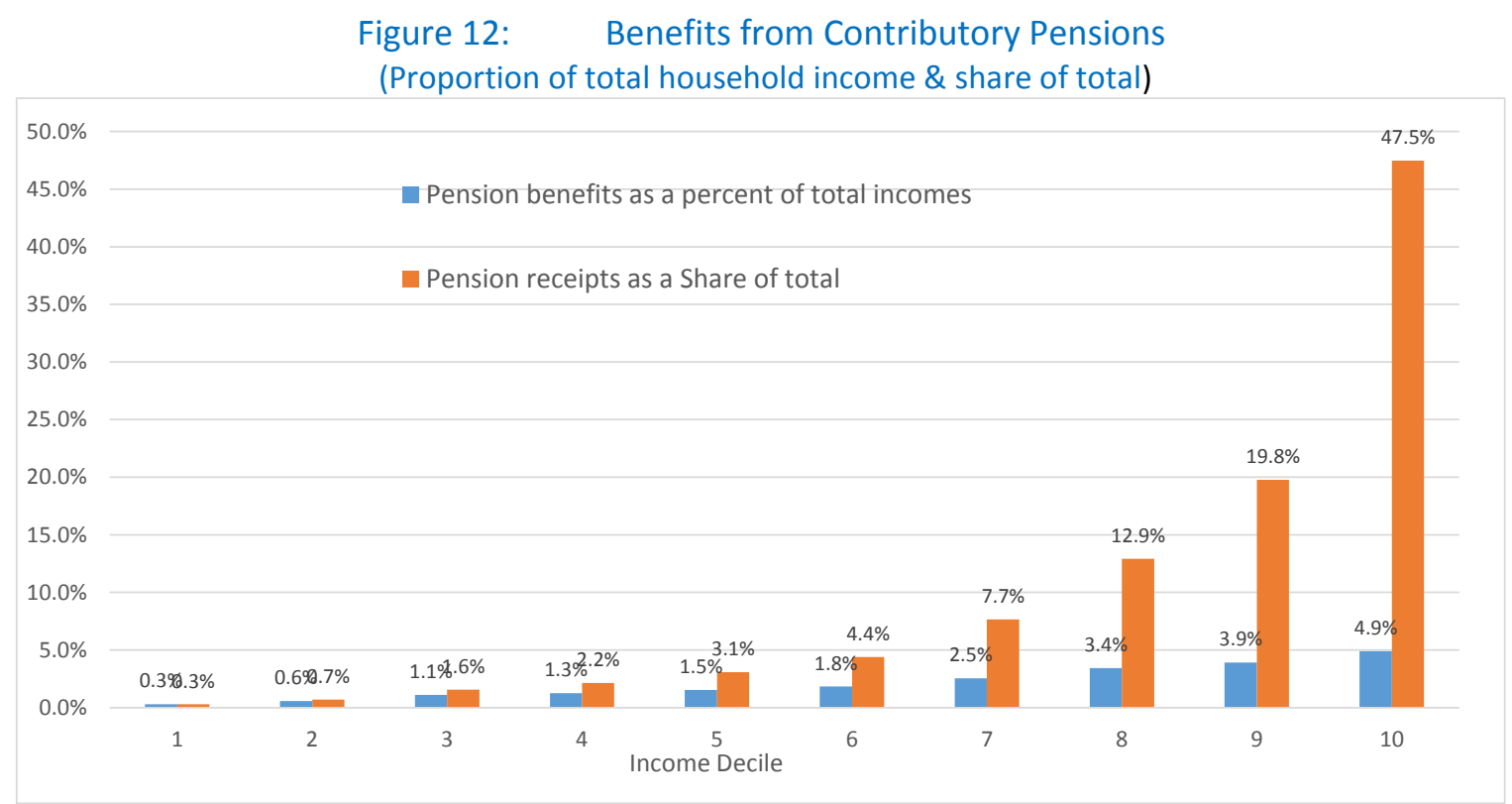

Source: NSO, Family Income and Expenditure Survey 2011, Table 3, Number of Families and Family Receipts by Income Decile. Note: The data includes all pension payments including those from SSS and GSIS.

41. The distribution of pension benefits largely mirrors the profile of contributors. Contributors tend to be higher-income workers with steady wages. These workers tend to be relatively well off in retirement, as well.

\section{Identification and Delivery Systems}

42. One particularly noteworthy administrative feature of the SSS (and GSIS) is the use of an identification system for their members, including biometric identification and smart-cards. An executive order in 2005 required all government agencies and government-owned and controlled corporations (GOCC) to streamline and harmonize their identification systems. In 2008, the social security identification system was identified as the core of the Unique Multi-Purpose Identification (UMID) system, and the SSS was instructed to lead in the streamlining and harmonization of the ID systems of all government agencies and GOCCs. Although the UMID card has been characterized as a unified card for transactions of four government agencies, namely: SSS, GSIS, PhilHealth, and Pag-IBIG (Home Development Mutual Fund), the databases are not linked between the agencies and there is no process for deduplication across agencies. In April 2015, the SSS announced the release schedule for its own UMID card, which can be used to view an individual's SSS profile and account, statistical information, SSS premiums, history, SSS loans, and balances. 
43. Importantly, the SSS database has de-duplication/reconciliation processes so that those members with SSS UMID cards can be ensured to be unique. Authentication is done initially through verification of birth certificates and establishment of biometric identifiers. Validation can be done at SSS offices as well as in banks. Inquiries are web-based, with authentication through pin numbers. ${ }^{28}$ The database of members will be materially strengthened as the SSS gradually issues UMID cards to replace earlier identification.

44. Measures have also been taken to improve SSS delivery systems. Registration has been automated online, and contributions and loan repayments can also be done online through two banks, including through a large network of ATMs. An online service portal (My.SSS) allows SSS members to have exclusive access to their contributions and membership records, make online transactions, and request copies of their records as needed. The online portal is not yet available on mobile phones, although efforts are being made to provide it in the near future.

\section{B. Social Pensions}

45. As stipulated by the Senior Citizens Act, the Department of Social Welfare and Development (DSWD) has provided a Social Pension benefit for indigent senior citizens since 2011. As of 2015, the scheme covered about 940,000 individuals or about 20 percent of those aged 65 and above (Table 4). Since its inception, the benefit has been PHP 500 (about US\$10.70) per month, paid quarterly. The cost in 2015 was about PHP 6.0 billion or 0.08 percent of GDP, having risen substantially since 2014 with a reduction in the age of qualification from 77 to 65 (Table 6).

Table 6: $\quad$ Social Pension Budgets

(PhP millions, \% of GDP)

\begin{tabular}{|l|r|r|r|r|r|}
\hline & \multicolumn{1}{|c|}{2011} & \multicolumn{1}{|c|}{2012} & \multicolumn{1}{|c|}{2013} & \multicolumn{1}{c|}{2014} & \multicolumn{1}{c|}{2015} \\
\hline Budgetfor Social Pension & 870 & 1,280 & 1,500 & 3,100 & 5,900 \\
\hline \% of GDP & $0.01 \%$ & $0.02 \%$ & $0.02 \%$ & $0.04 \%$ & $0.08 \%$ \\
\hline
\end{tabular}

Source: DSWD.

46. Aside from being identified as poor by the national household targeting system Listahanan, ${ }^{29}$ beneficiaries must meet other eligibility criteria. The beneficiary must: (i) be frail, sickly, or with disability; (ii) not receive a pension such as from SSS, GSIS, or an occupational pension; and (iii) be without a permanent source of income, compensation, or financial assistance from his/her relatives to support his/her basic needs. From 2011 through 2014, the benefit was limited to those age 77 and above, but since January 2015, the beneficiary must be 65 years old and above. Applicants must obtain a

\footnotetext{
${ }^{28}$ The authors are not aware of an applet for web-based communication with SSS for members.

${ }^{29}$ Listahanan is a national household targeting system hosted by DSWD. Originally, it was established in 2008 to support the conditional cash transfer program. In 2009/10, data from about 11 million or $60 \%$ of Filipino households was collected of which 5.3 million were identified as poor. In 2010, a presidential decree was issued obliging all government agencies to use Listahanan to identify poor beneficiaries of Government's poverty reduction programs. In 2015, DSWD collected information from 75\% of Filipino households (15.1 million) to update Listahanan. Listahanan uses a proxy means method to estimate per capita income of surveyed households and provincial poverty lines to identify the poor. The list of poor households are verified by communities for accuracy and transparency, before being finally determined.
} 
Senior Citizen's Identification Card (OSCA ID) issued by local government units (LGUs). Obtaining such an ID requires other valid identification or a birth certificate.

47. Payments are made quarterly as follows: (i) direct cash payments are made to beneficiaries by designated Disbursement Officers of DSWD; (ii) funds are transferred to the LGU that is charged with disbursing to final beneficiaries; and (iii) door-to-door delivery can be done by an identified social provider.

48. The DSWD program compares relatively well to its peers in the EAP (Table 7). The key design variables for elderly assistance programs are the benefit level and indexation, means testing, and age and other eligibility conditions. These parameters are established in light of the fiscal resources available to support the benefit as well as tradeoffs with other development priorities. Table 7 provides a comparison of the Philippines Social Pension with other elderly assistance programs in the EAP region. One should however keep in mind that programs are not strictly comparable, because of differing eligibility requirements.

Table 7: $\quad$ Summary of Elderly Assistance Programs in the East Asia and Pacific Region

\begin{tabular}{|c|c|c|c|c|c|c|c|c|c|}
\hline Country & Name of scheme & PPP $\${ }^{\star *}$ & $\begin{array}{l}\% \text { of GDP } \\
\text { per capita* }\end{array}$ & $\begin{array}{l}\% \text { of } \$ 1.25 \\
\text { poverty } \\
\text { line } e^{\star \star \star}\end{array}$ & $\begin{array}{l}\text { Age of } \\
\text { eligibillity }\end{array}$ & Targeting & $\begin{array}{l}\% \text { population } \\
60+\text { covered }\end{array}$ & $\begin{array}{l}\text { \% of population } \\
\text { over eligibility } \\
\text { covered }\end{array}$ & $\begin{array}{l}\text { Total cost } \\
\text { (\% of GDP) }\end{array}$ \\
\hline China & Rural social pension & 13 & $1 \%$ & $34 \%$ & 60 & NA & $48 \%$ & $75 \%$ & $0.11 \%$ \\
\hline Hong Kong & Normal/higher old age allowance & 196 & $4 \%$ & $515 \%$ & $\begin{array}{l}65 \text { (normal } \\
\text { OAA), } 70 \\
\text { (Higher OAA) }\end{array}$ & Means-tested & $42 \%$ & $61 \%$ & $0.38 \%$ \\
\hline Indonesia & $\begin{array}{l}\text { Program Jaminan Sosial Lanjut } \\
\text { Usia (JSLU) (Elderly Social } \\
\text { Security Programme) (Pilot) }\end{array}$ & 41 & $9 \%$ & $107 \%$ & $\begin{array}{l}70 \text { (60 if } \\
\text { chronically ill) }\end{array}$ & Means-tested & $0 \%$ & $0 \%$ & NA \\
\hline $\begin{array}{l}\text { Korea, } \\
\text { Republic of }\end{array}$ & Basic old-age pension & 114 & $4 \%$ & $300 \%$ & 65 & Means-tested & $50 \%$ & $70 \%$ & $0.30 \%$ \\
\hline Malaysia & $\begin{array}{l}\text { Bantuan Orang Tua (Elderly } \\
\text { assistance scheme) }\end{array}$ & 157 & $10 \%$ & $414 \%$ & 60 & Means-tested & $6 \%$ & $9 \%$ & $0.04 \%$ \\
\hline Mongolia & Social welfare pension & 33 & $6 \%$ & $87 \%$ & $\begin{array}{l}60 \text { (men) } 55 \\
\text { (women) }\end{array}$ & Means-tested & $2 \%$ & $3 \%$ & $0.02 \%$ \\
\hline Philippines & Social Pension & & $8.3 \%$ & $29 \%$ & 65 & Means-tested & $13 \%$ & $21 \%$ & $0.08 \%$ \\
\hline Thailand & Old Age Allowance & 33 & $4 \%$ & $88 \%$ & 60 & Pensions-tested & $64 \%$ & $94 \%$ & $0.32 \%$ \\
\hline Viet Nam & $\begin{array}{l}\text { Social assistance benefit (category } \\
\text { 2) }\end{array}$ & 21 & $6 \%$ & $56 \%$ & 60 & NA & NA & NA & $0.01 \%$ \\
\hline
\end{tabular}

Source: Bank estimates (Philippines); Pensions-watch social pensions database, 2015, http://www.pension-watch.net/aboutsocial-pensions/about-social-pensions/social-pensions-databasel

49. The benefit level appears to be adequate for most elderly poor. The benefit represented about 8.3 percent of GDP per capita in 2014. While the benefit covers only about 28 percent of the national per capita poverty threshold, it is very close to the poverty income gap on a per capita basis. However, the benefit level is not indexed, subjecting beneficiaries to price risk. No adjustments have been made since it was introduced in 2011 resulting in a decline in the real value of the benefit by about 15 percent. However, the coverage was extended by lowering the qualifying age from 77 to 65 , indicating that the tradeoff was in favor of expanding the coverage.

50. Some concerns have also been raised over possible targeting errors. As no targeting system is perfect, targeting errors could include exclusion errors (individuals who are poor and should get a Social Pension benefit but do not) and inclusion errors (individuals who should not be classified as poor but have been and have therefore qualified for Social Pension benefits). The Listahanan update in 2015 is 
expected to correct the errors to a large extent. In addition, there is a mechanism through which any individual may demand to be reassessed.

\section{Parametric Reforms to the Social Security System}

\section{In this section we present options for the reform of the SSS scheme parameters that the SSS}

may consider to strengthen its financial sustainability. At the same time such reform options can also improve the incentives and equitability of benefits. We used the Pension Reform Options Simulation Toolkit (PROST) to project the baseline and the impact of four reform packages. ${ }^{30}$ The packages of reforms are intended to serve as examples to illustrate the impact of changes in parameters and qualifying conditions. The packages involve those key design parameters and eligibility conditions which can be adjusted to achieve the desired objectives. Our intention is to illustrate the impact of each reform as well as the interactive effects between the different reform packages. The projected financing gap was evaluated (to assess sustainability), and replacement rates were calculated (to assess adequacy). Table 8 summarizes the parametric reforms and the rationale behind them, and Table 9 summarizes the projection results for each of the reform packages.

${ }^{30}$ The Pension Reform Options Simulation Toolkit (PROST) is a proprietary modeling program developed by the World Bank which has been used to simulate pension and social security finances and evaluate reform options in over 100 countries worldwide (See Annex 1). 
Table 8: $\quad$ Summary of SSS Parametric Reform Packages and Their Impacts

\begin{tabular}{|c|c|c|c|c|c|}
\hline & & Incentives & Sustainability & $\begin{array}{c}\text { Equitability or } \\
\text { Adequacy of Risk } \\
\text { Coverage } \\
\end{array}$ & $\begin{array}{l}\text { Adequacy - } \\
\text { Avg. Benefit }\end{array}$ \\
\hline \multicolumn{6}{|c|}{ Package 1 (Reforms 1A-C) } \\
\hline $\begin{array}{l}\text { Reform } \\
1 \mathrm{~A}\end{array}$ & $\begin{array}{l}\text { Harmonizing } \\
\text { benefit formula } \\
\text { for all (moving to } \\
\text { PHP } 300+2 \% \text { per } \\
\text { year of } \\
\text { contributions for } \\
\text { any number of } \\
\text { years of } \\
\text { contributions = } \\
10 \text { and above; } \\
\text { introduced } \\
\text { gradually over } 5 \\
\text { years) }\end{array}$ & $\begin{array}{l}\text { Substantially increases } \\
\text { the incentives to } \\
\text { participate for those } \\
\text { with } 10-20 \text { years of } \\
\text { service. }\end{array}$ & $\begin{array}{l}\text { Impact depends } \\
\text { on behavioral } \\
\text { change (not } \\
\text { modeled). No } \\
\text { behavioral change } \\
\text { increases } \\
\text { sustainability as } \\
\text { replacement rates } \\
\text { for workers with } \\
\text { 10-20 years of } \\
\text { service are } \\
\text { reduced. }\end{array}$ & $\begin{array}{l}\text { Each year of } \\
\text { contributory service is } \\
\text { awarded an equal level } \\
\text { of income replacement } \\
\text { through the accrual } \\
\text { rate. }\end{array}$ & $\begin{array}{l}\text { Reduces } \\
\text { average } \\
\text { replacement } \\
\text { rate largely } \\
\text { due to the } \\
\text { impact for } \\
\text { workers with } \\
10-20 \text { years of } \\
\text { service. }\end{array}$ \\
\hline $\begin{array}{l}\text { Reform } \\
1 B\end{array}$ & $\begin{array}{l}\text { Moving from 5- } \\
\text { year average } \\
\text { wage (not } \\
\text { valorized) to } \\
\text { lifetime average } \\
\text { wage valorized } \\
\text { to wages as the } \\
\text { income measure } \\
\text { used in pension } \\
\text { calculations }\end{array}$ & $\begin{array}{l}\text { Removes incentives to } \\
\text { elevate wage base } 5 \\
\text { years before } \\
\text { retirement. }\end{array}$ & $\begin{array}{l}\text { Reduces } \\
\text { sustainability by } \\
\text { increasing average } \\
\text { replacement rates. }\end{array}$ & $\begin{array}{l}\text { Equalizes lifetime } \\
\text { income replacement } \\
\text { between those with } \\
\text { sharp age/wage } \\
\text { profiles and those } \\
\text { with low growth in } \\
\text { lifetime wages. } \\
\text { - Equalizes effective } \\
\text { income replacement } \\
\text { between those } \\
\text { whose wage base is } \\
\text { during a period of } \\
\text { rapid/slow growth. }\end{array}$ & $\begin{array}{l}\text { Changes in } \\
\text { the average } \\
\text { replacement } \\
\text { rates depend } \\
\text { on the shape } \\
\text { of the age- } \\
\text { earnings } \\
\text { profile. }\end{array}$ \\
\hline $\begin{array}{l}\text { Reform } \\
1 C\end{array}$ & $\begin{array}{l}\text { Introducing full } \\
\text { and automatic } \\
\text { inflation } \\
\text { indexation for } \\
\text { post-reform } \\
\text { pensions (instead } \\
\text { of current } \\
\text { average trend of } \\
\text { annual average at } \\
\text { about } 60 \% \text { of } \\
\text { inflation rate) }\end{array}$ & $\begin{array}{l}\text { Improves worker } \\
\text { confidence in the ability } \\
\text { of the benefit to } \\
\text { smooth consumption } \\
\text { during retirement, thus } \\
\text { improving the cost- } \\
\text { benefit ratio from the } \\
\text { workers' perspective } \\
\text { and increasing } \\
\text { incentives to } \\
\text { participate. }\end{array}$ & $\begin{array}{l}\text { Increases average } \\
\text { benefits in } \\
\text { retirement, } \\
\text { therefore } \\
\text { decreases } \\
\text { sustainability. }\end{array}$ & $\begin{array}{l}\text { Automatic indexation } \\
\text { improves inter- } \\
\text { generational equity } \\
\text { because retirees are } \\
\text { not negatively affected } \\
\text { by under-indexation of } \\
\text { benefits. }\end{array}$ & $\begin{array}{l}\text { Inflation } \\
\text { indexation } \\
\text { protects } \\
\text { retirees } \\
\text { against the } \\
\text { risk of loss of } \\
\text { purchasing } \\
\text { power. }\end{array}$ \\
\hline Reform 2 & $\begin{array}{l}\text { Increasing the } \\
\text { (minimum) } \\
\text { retirement age }\end{array}$ & $\begin{array}{l}\text { Increases incentive to } \\
\text { work longer. }\end{array}$ & $\begin{array}{l}\text { Improves } \\
\text { sustainability. }\end{array}$ & No change. & No change. \\
\hline Reform 3 & $\begin{array}{l}\text { Reducing the } \\
\text { marginal accrual } \\
\text { rate }\end{array}$ & $\begin{array}{l}\text { Reduces the benefit } \\
\text { relative to cost } \\
\text { (contributor's } \\
\text { perspective). }\end{array}$ & $\begin{array}{l}\text { Improves } \\
\text { sustainability. }\end{array}$ & No change. & $\begin{array}{l}\text { Decreases } \\
\text { benefit \& } \\
\text { replacement } \\
\text { rate. }\end{array}$ \\
\hline Reform 4 & $\begin{array}{l}\text { Increasing the } \\
\text { contribution rate } \\
\text { to } 15 \% \text { between } \\
2031-2035\end{array}$ & \multirow[t]{2}{*}{$\begin{array}{l}\text { Increases the cost of } \\
\text { participation } \\
\text { (contributor's } \\
\text { perspective). }\end{array}$} & $\begin{array}{l}\text { Improves } \\
\text { sustainability. }\end{array}$ & No change. & No change. \\
\hline Reform 4a & $\begin{array}{l}\text { Increasing the } \\
\text { contribution rate } \\
\text { to } 18 \% \text { between } \\
2031-2035\end{array}$ & & $\begin{array}{l}\text { Achieves full long- } \\
\text { term } \\
\text { sustainability. }\end{array}$ & No change. & No change. \\
\hline
\end{tabular}


Table 9: $\quad$ Summary of the Financial Effects of SSS Baseline and Simulated Reforms ${ }^{31}$

\begin{tabular}{|l|c|c|c|}
\hline \multicolumn{1}{|c|}{ Reform scenario } & $\begin{array}{c}\text { Financing } \\
\text { gap* }\end{array}$ & $\begin{array}{c}\text { Break-even } \\
\text { point** }\end{array}$ & $\begin{array}{c}\text { Assets depletion } \\
\text { point*** }\end{array}$ \\
\hline baseline (no reform) & $(34 \%)$ & 2036 & 2044 \\
\hline Reform A & $(29 \%)$ & 2038 & 2046 \\
\hline Reform B & $(44 \%)$ & 2032 & 2040 \\
\hline Reform C & $(43 \%)$ & 2032 & 2040 \\
\hline & & & 2038 \\
\hline Package 1 & $(48 \%)$ & 2030 & 2046 \\
\hline Package 2 & $(36 \%)$ & 2037 & 2049 \\
\hline Package 3 & $(23 \%)$ & 2040 & 2063 \\
\hline Package 4 & $(11 \%)$ & 2054 & 2079 \\
\hline Package 4a & $(1 \%)$ & 2068 & \\
\hline
\end{tabular}

* \% of 2013 GDP, with $4 \%$ real discount rate.

** Year when the annual current balance turns negative.

*** Year when Pension Fund's own assets are depleted and government needs to step in to cover deficits.

Separate interventions (reform starts in 2017):

Reform A: harmonizing benefit formula for all (moving to PHP $300+2 \%$ per year of contributions for any number of years of contributions $=10$ and above; introduced gradually over 5 years)

Reform B: moving from 5-year average wage (not valorized) to lifetime average wage valorized to wages as the income measure used in pension calculations

Reform C: introducing full inflation indexation for post-reform pensions (instead of current average trend of annual average at about $60 \%$ of inflation rate)

Reform packages (reform starts in 2017):

Package 1: Reform 1 + Reform 2 + Reform 3

Package 2: Package $1+$ increase retirement age (to age 65 over 10 years, then gradually to age 68 by 2080)

Package 3: Package $2+$ accrual rate reduced to $1.5 \%$, applied to post-reform years of contribution

Package 4: Package $3+$ contribution rate increased to $15 \%$ between 2031 and 2035 (by 1 p.p. per year)

Package 4a: Package $3+$ contribution rate increased to $18 \%$ between 2031 and 2035 (by 1 p.p. per year)

52. Four packages of parametric reforms for the SSS have been evaluated which are intended to achieve sustainability, strengthen incentives for participation and wage reporting, improve the coverage of inflation risks during retirement, and moderate the contribution rate to ensure affordability. ${ }^{32}$ Although the four packages of reforms evaluated can together achieve these objectives, we suggest that the authorities use the proposed parametric changes as a starting point to further

${ }^{31}$ Key assumptions are provided in Annex 1.

32 One reform program which the Bank did not model was a Filipino proposal to increase SSS pensions by 2,000 PHP per month. Logically, a piecemeal pension increase of such a large magnitude (over $50 \%$ on average) without concomitant public subsidies or increases in contributions would have a profound adverse impact on the sustainability of the SSS. Such adverse impact on SSS system finances would place a substantial additional burden on SSS members to sustain their promised benefits. Alternatively, some of the future promised benefits may not be able to be delivered unless alternative financing sources are found. 
evaluate a combination of reforms that best weighs the tradeoffs between fiscal cost, sustainability, adequacy and coverage suggested. Projections can be useful in helping policymakers identify the package of parametric reforms that would best meet their objectives for the SSS.

53. The objective of the reforms proposed in Reform Package 1 (Reforms $A-C$ ) is to improve the incentives for participation and to promote greater equity among workers of different incomes and different service lengths. Reform A would harmonize the accrual rate and equalize the incentives for workers to contribute regardless of their service histories. Reform B would extend the wage base and valorize the base according to covered wage growth. ${ }^{33}$ This would remove a subtle regressive effect of the current benefit formula whereby the lifetime income replacement rate is equalized between those with sharp increases in lifetime wages and those with lower increases. ${ }^{34}$ Reform C would establish automatic inflation indexation of benefits to protect retirees from inflation during retirement. This can improve worker confidence in the ability of the benefit to smooth consumption during retirement, thus improving the cost-benefit ratio from the workers' perspective.

\section{The three reforms in Package 1 (A-C) would have impacts on the sustainability of the SSS} scheme and on replacement rates both for new retirees and for all retirees (Figure 13, Figure 14, Figure 15). Establishing a linear accrual rate would somewhat improve sustainability, as workers with between 10-20 years of contributions would receive lower replacement rates. Valorization of the wage base would increase the replacement rate and reduce sustainability, more than offsetting the improvement through the linear accrual rate. Automatic indexation of benefits to inflation would somewhat affect the financing gap because the growth of benefits through indexation would be substantially better than those observed over the past two decades. Together, the package of three parametric reforms would increase the financing gap by about 14 percentage points and move up the break-even point from the baseline 2036 to 2030 (Figure 13).

\footnotetext{
${ }^{33}$ This would be a gradual process whereby the salary reference period could be increased at a pace consistent with recordkeeping capacity, such as increasing the wage base at a pace of one year per year after the reform is established. To illustrate the effect of reform A

${ }^{34}$ On average, cross-country data suggests that those with high incomes at retirement tend to have sharper rises in wages during their work histories compared to those with relatively low salaries. As a result, if one were to calculate the individual lifetime replacement rate - that is, the benefit under the existing benefit formula as a proportion of the lifetime individual covered wage (valorized or indexed by the growth in the average wage) those individuals with high pre-retirement incomes would have higher replacement rates compared to workers with low incomes, assuming that both types of workers have the same work histories.
} 
Figure 13: $\quad$ SSS - Baseline and Reforms A, B, \& C - Impact on Sustainability - Annual Current Balance (Percent of GDP)

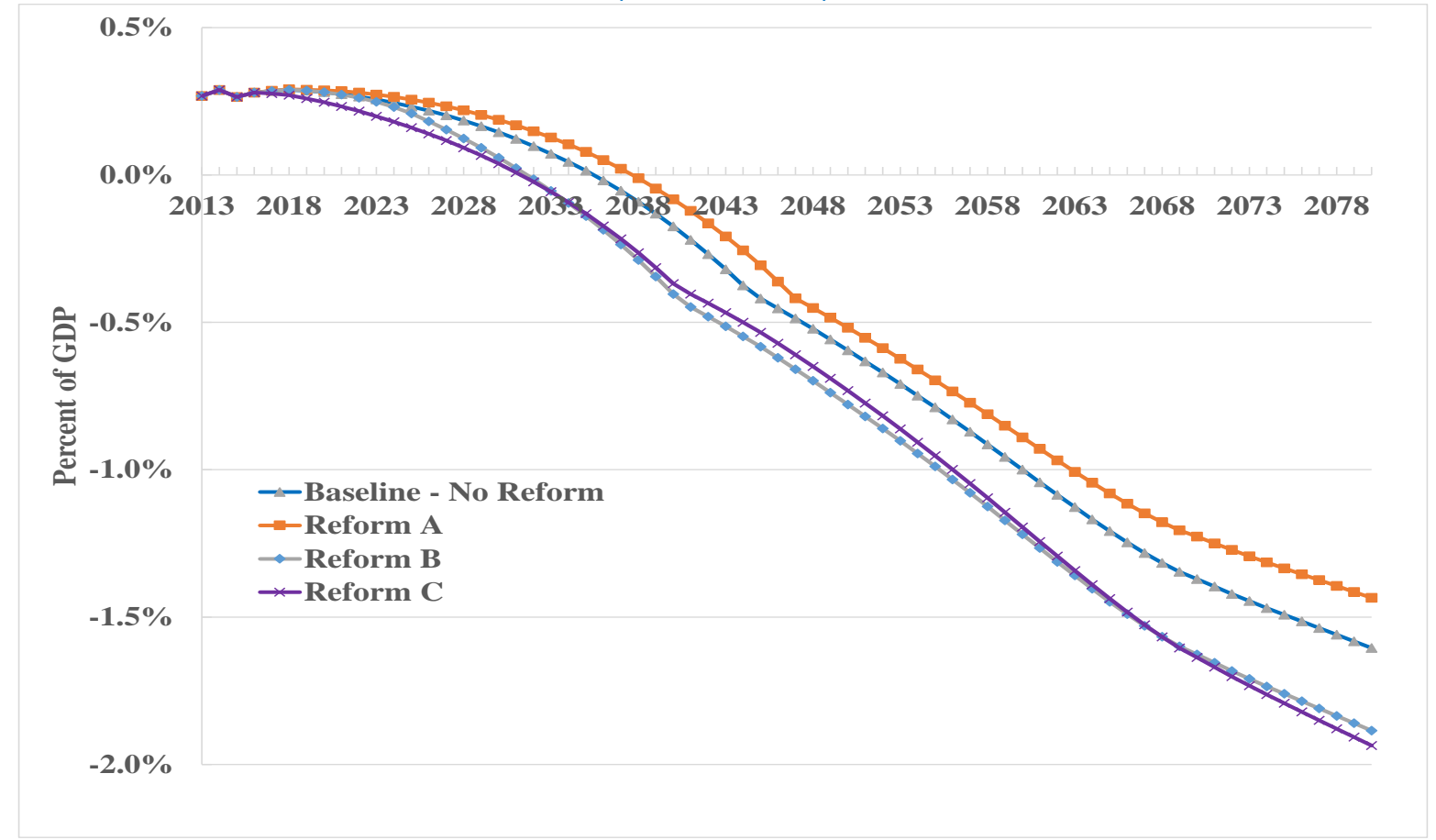

Source: World Bank estimates.

Figure 14: $\quad$ SSS - Impact of Reform Packages on Sustainability - Annual Current Balance (Percent of GDP)

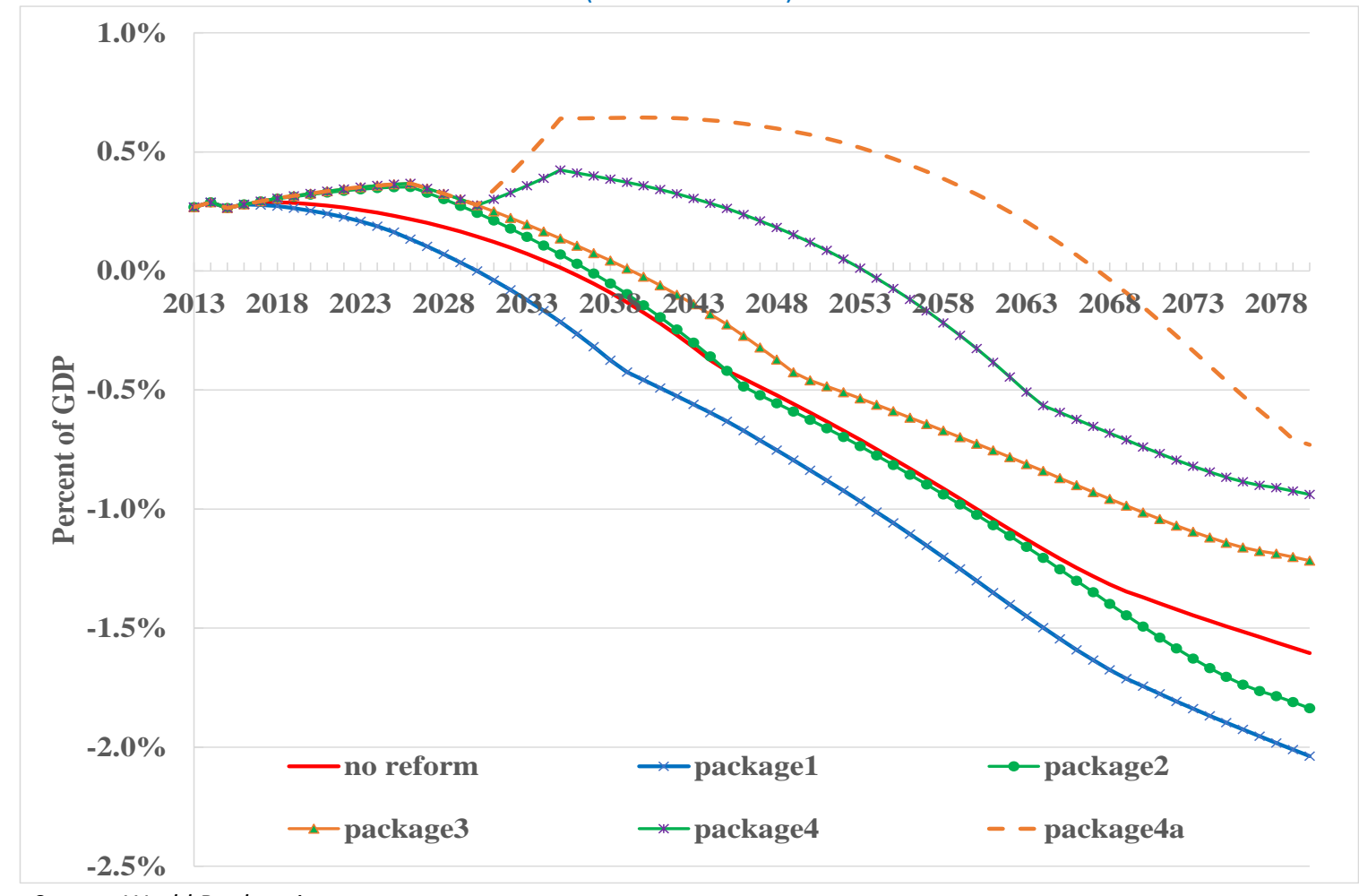

Source: World Bank estimates. 
55. The second reform package to gradually increase the minimum retirement age from 60 to 65 would increase incentives to work longer and improve sustainability (Figure 14, Figure 15).

Subsequently, the retirement age could be increased to in line with increases in life expectancy at retirement age to maintain a life expectancy of 15 years at retirement. ${ }^{35}$ Increasing the minimum retirement age by 5 years would decrease the projected years in retirement by about 3.4 years thereby having a significant impact on SSS financial sustainability (Figure 16). ${ }^{36}$ By comparison, over the past 35 years, life expectancy at age 60 has increased 0.7 percentage points and is projected to increase further by 1.8 percentage points over the coming 35 years. Regional data suggests that the Philippines had relatively low life expectancy at retirement ages in 2015 (Figure 17). Increasing the retirement age is an essential parametric reform which results from the gradual decline in the fertility rate among the SSScovered population and the increase in life expectancy. These same characteristics have led many countries globally to increase the retirement age and put in place stronger incentives to keep individuals in the labor force as they get older. In addition, the benefit provided for retirees retiring earlier than the minimum retirement age should be subject to an actuarially fair benefit penalty, and those retiring after the minimum retirement age should receive an actuarially fair supplement that would have the effect of ensuring actuarial fairness of benefits among those retiring at different ages, therefore removing the current disincentive to work longer. ${ }^{37}$ The penalties and supplements would also enable workers to make retirement choices that fit their needs and circumstances.

\footnotetext{
${ }^{35}$ Although we chose a target life expectancy at retirement of 15 years, other targets could also be modeled and considered. The logic of aligning the retirement age with life expectancy at retirement contributes to a financial balance by maintaining a fixed number of years in retirement as life expectancy increases at the retirement age. ${ }^{36}$ These figures are based on mortality for the entire country. Cross-country data suggests that it is very likely that the SSS retirees have longer life expectancies at retirement ages.

${ }^{37}$ In addition, the labor law provides for mandatory retirement at age 65 , which this analysis suggests should be eliminated.
} 
Figure 15: $\quad$ SSS - Impact of Reform Packages on All Retirees' Replacement Rate (Percent of average full wage for all retirees)

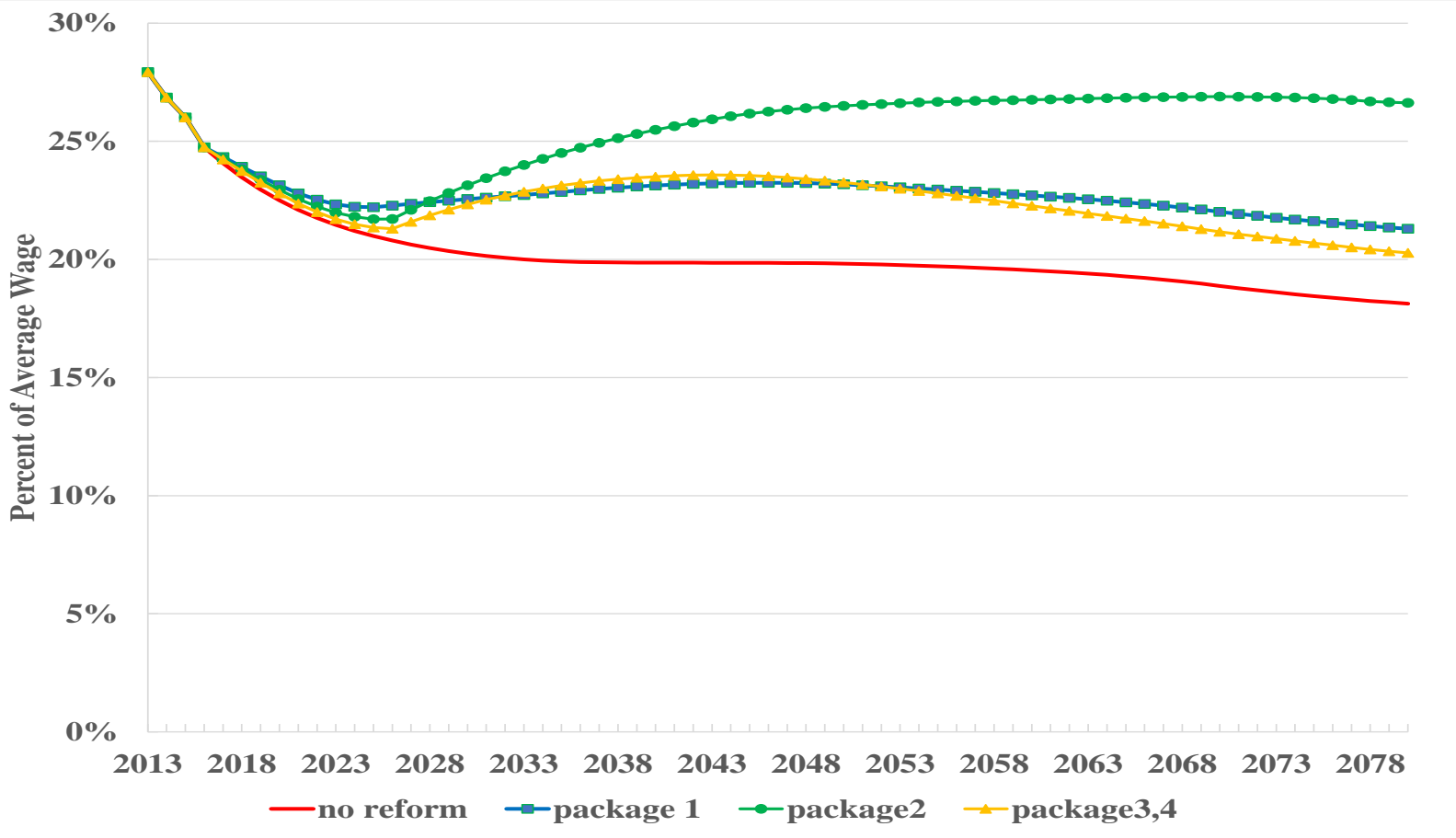

Source: World Bank estimates.

Figure 16: Life Expectancy at Retirement Ages

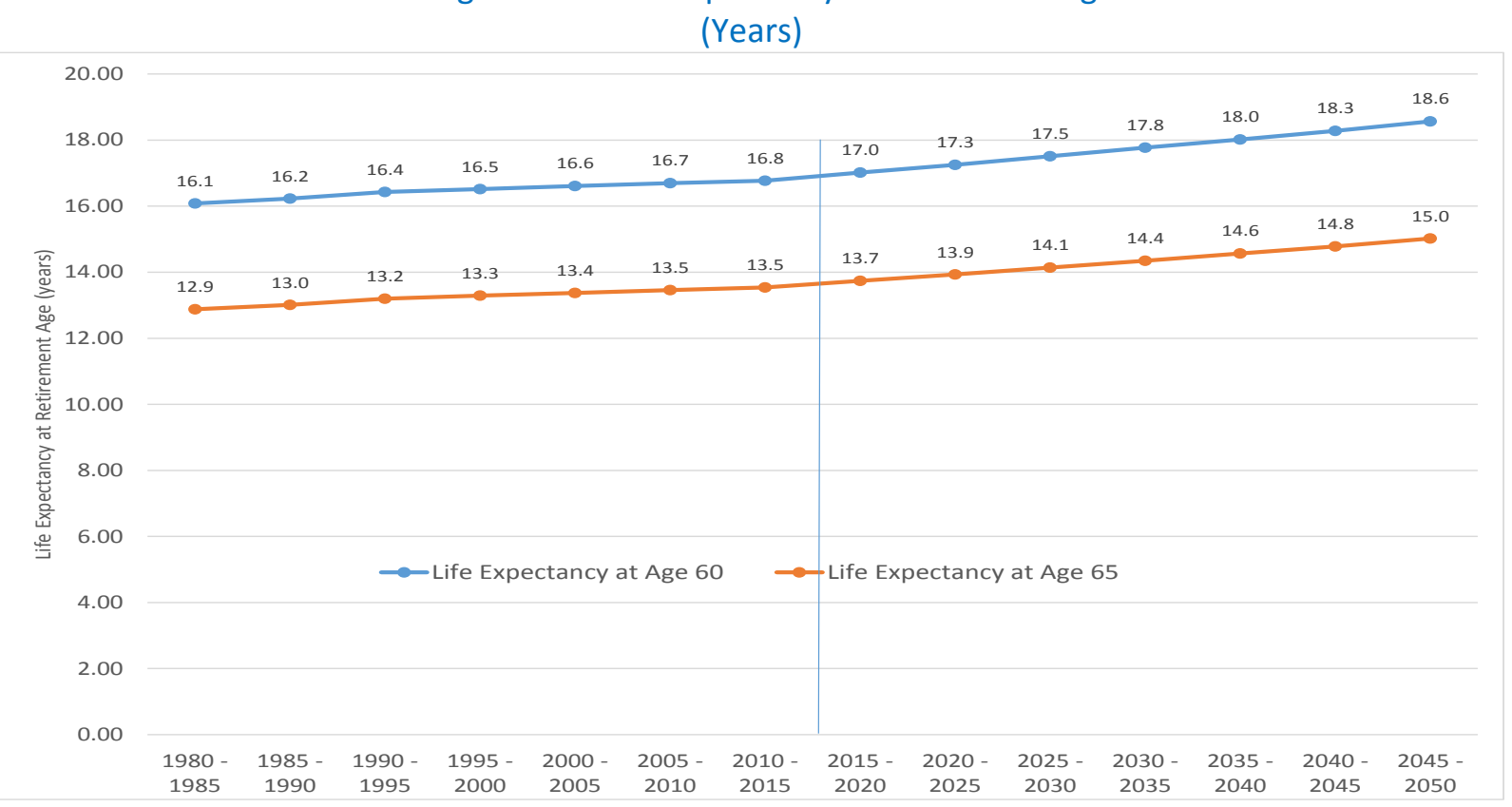

Source: World Population Prospects, the 2015 Revision. 
Figure 17: Life Expectancy at Retirement Ages in East Asia

(Years)

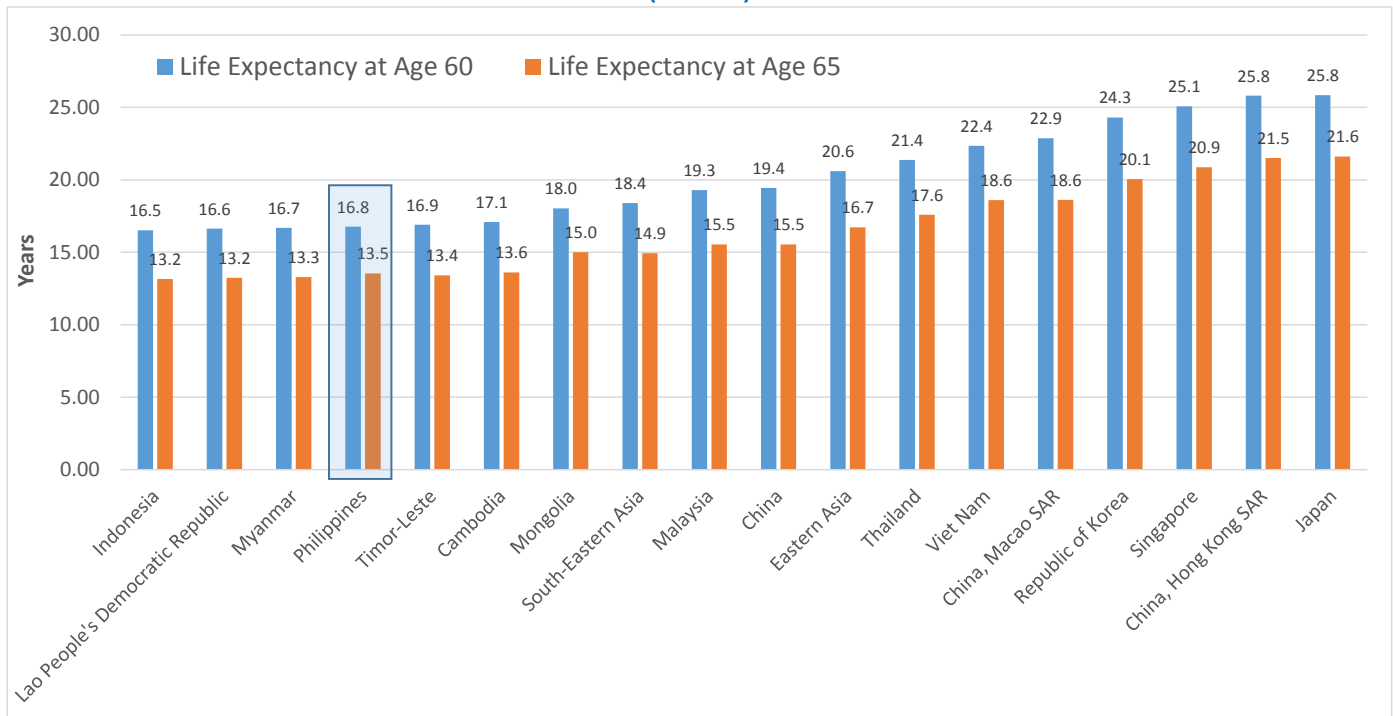

Source: World Population Prospects, the 2015 Revision.

56. The impact of the third reform package (which would gradually reduce the marginal accrual rate) would be a gradual reduction in replacement rates at retirement and some strengthening in system finances (Figure 14, Figure 15). ${ }^{38}$ This would reduce rights accrued after initiation of the reform and would not impact rights accrued prior to the reform. The replacement rate and financial flows would be only fully adjusted after about 40 years. The impact on the financing gap would be a reduction (from the scenario for Package 2) from 36 percent of GDP to 23 percent, a reduction of 13 percentage points.

\section{The fourth reform package illustrates the quantitative effect of an increase in the total} contribution rate from 11 percent to 15 percent (Figure 14, Figure 15). Such an increase begins in 2031 under the assumption that it would make limited sense to levy a contribution increase in the short term based on financial flows that only become negative over the long term. This package of contribution increases need to be considered in the context of the overall tax wedge as discussed further below. ${ }^{39}$

58. Finally, for illustrative purposes, a variant on the fourth reform package was modeled which increases the total contribution rate sufficiently to eliminate the projected financing gap by 2080 (Figure 14, Figure 15). Eliminating the financing gap would require an 18 percent contribution rate beginning in 2031. Table 10 illustrates the effects of such contribution increases for workers at different wage levels. A contribution rate increase is not suggested to be enacted in the short-run because the demographics, coverage and financial flows will change over time and could end up being more favorable than projected currently. Rather, it is suggested that this issue of a long-term contribution rate required for financing equilibrium be revisited with each SSS actuarial valuation and that a decision

\footnotetext{
${ }^{38}$ The reduction in the accrual rate by 0.5 percent per year and the timing over five years is meant as a reference point only. The actual reduction and phasing should be calibrated to the circumstances, including the political economy dimensions.

${ }^{39}$ As noted above, the level of contribution increase and the phasing are meant as illustrations of the effects. The actual reform parameters adopted should be determined with the support of additional modeling.
} 
be reached over the coming 15 years when the projected longer-term financing gap will be known with greater certainty.

Table 10: Illustrative Contributions at Different Contribution Rates

(monthly PHP)

\begin{tabular}{|l|r|r|r|}
\hline & $\begin{array}{c}\text { Minimum } \\
\text { Covered } \\
\text { Wage } \\
\text { Worker }\end{array}$ & $\begin{array}{c}\text { Average } \\
\text { Wage } \\
\text { Worker * }\end{array}$ & $\begin{array}{c}\text { Maximum } \\
\text { Covered } \\
\text { Wage }\end{array}$ \\
\hline Monthly Covered Wage & 1,000 & 15,381 & 16,000 \\
\hline Monthly Contribution (11\%) & 110 & 1,692 & 1,760 \\
\hline Monthly Contribution (15\%) & 150 & 2,307 & 2,400 \\
\hline Monthly Contribution (18\%) & 180 & 2,769 & 2,880 \\
\hline
\end{tabular}

*Note: Average wage is at end-2013. The minimum and maximum Covered wage were at 2015. Actual wages in the proposed years for Increasing contributions will be higher so that these figures are for Illustrative purposes.

59. Although periodic increases in the contribution rate were enacted in the past to improve sustainability, future increases should be considered in the context of the overall tax wedge, as such measures will likely affect worker coverage and compliance. The tax wedge is the overall set of additional costs of labor in addition to wages and includes social security contributions, health insurance contributions, personal income tax rates, severance payments, the cost of minimum wage policies, and any other non-wage labor costs. As suggested in Figure 18 below, marginal tax rates are very steep, so just these costs represent a substantial cost for labor and create a strong incentive for wage underreporting and tax avoidance. It is therefore important to model different levels and timing of increases in the contribution rate and reductions in the marginal accrual rate to see which mix can best achieve the sustainability objective, while also managing the affordability of contributions and adequacy of benefits.

Figure 18: Social Security and Personal Income Tax Rates

(2013)

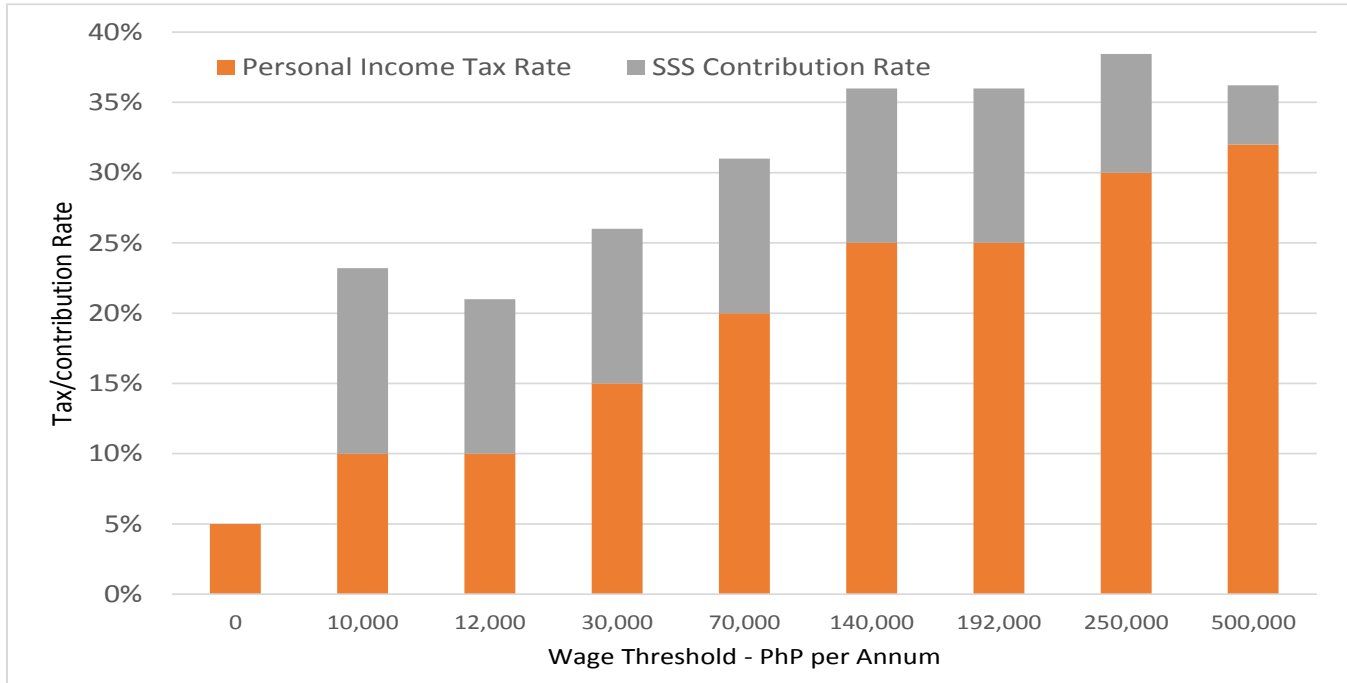

Source: OECD, Pensions at a Glance Asia/Pacific, p. 80; World Bank estimates. 
60. Together, these parametric reforms could have the effect of improving sustainability, adequacy, equitability, and participation incentives (Figure 19). The proposed and modeled parametric changes would improve the projected long-term sustainability of SSS financing, improve inflation risk coverage (through indexation), strengthen work incentives (through retirement age and benefit adjustments), and improve equitability among workers with different salary profiles (through an improved benefit formula). Transition provisions have been proposed which aim to make the adjustments in benefits and contributions smooth, thereby avoiding disruptive shocks to workers and retirees. Of course, achieving sustainability is not without cost, namely in terms of increased contributions and reduced marginal benefit levels.

Figure 19: $\quad$ SSS Reforms - Summary of Projected Financing Gaps and Break-Even Points

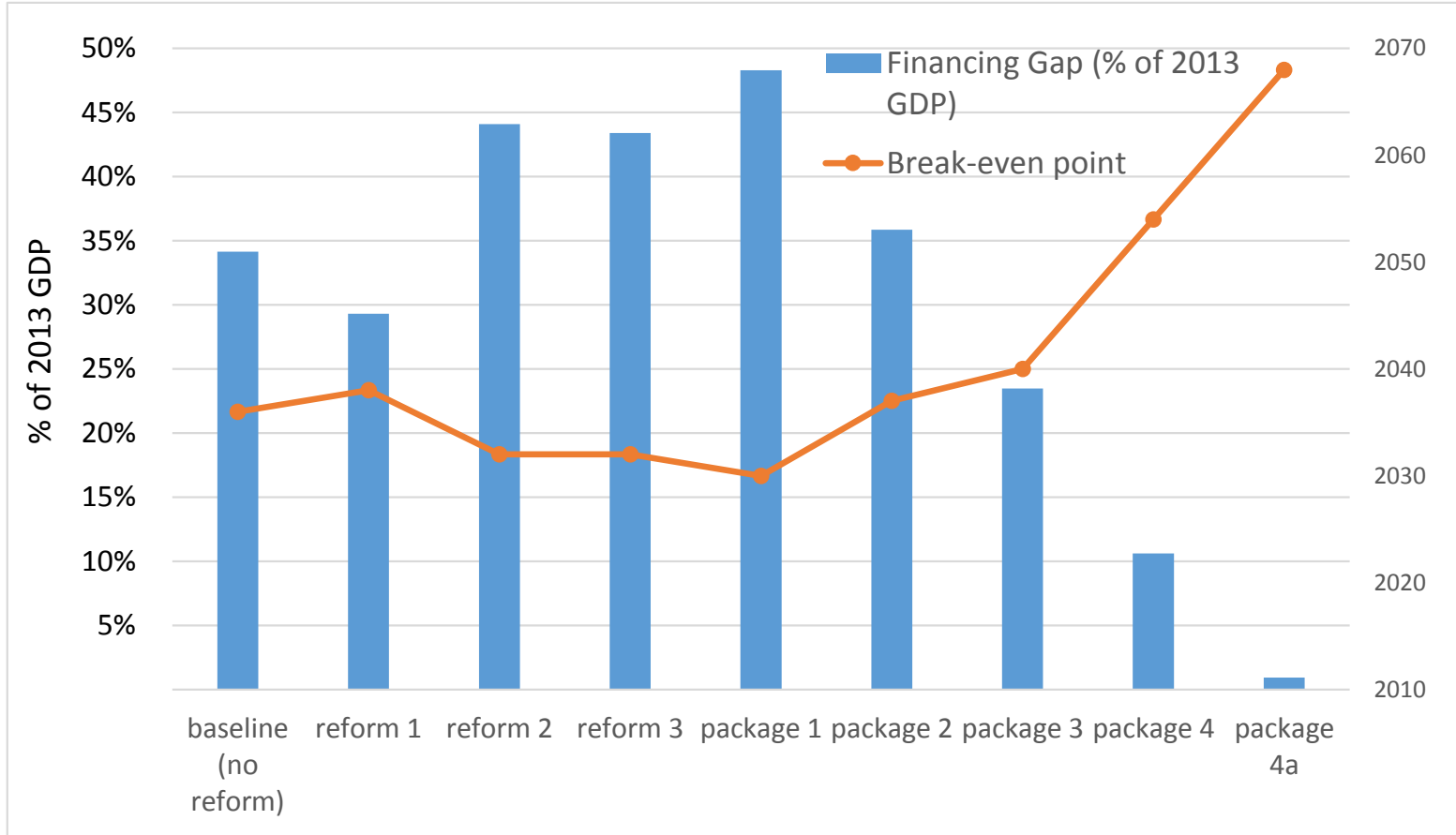

Source: World Bank estimates.

\section{Options to Consider to Improve Coverage}

\section{A. Overall Considerations to Increase Social Security Coverage and Income Protection in Old Age}

61. The most important and sustainable remedy to improve social security coverage is to improve the quantity and quality of wage-based employment - measures which are beyond the scope of the SSS scheme design or delivery systems. Low worker coverage and contribution densities mirror the limited steady wage-based jobs for most Filipino workers. Low and intermittent incomes often from small companies or agriculture, self-employed or single proprietors present formidable challenges both to economic stability as well as provide a weak basis for contributing to social security. Measures are needed to reduce the barriers to employment generation, which include a weak investment climate and costly business, tax, and labor market regulations. Moreover, weaknesses in skills need to be addressed. Overall, higher productivity jobs are essential for coverage expansion. 
62. Measures to increase worker coverage are needed to increase the probability that workers will have a steady source of income from social security once they reach old age. Support elderly receive from other household/family members are subject to non-diversifiable unemployment, health, and natural disaster risks, which the elderly can only diversify with alternative sources of income in retirement. Moreover, the large number of elderly who are dependent on household income support is increasing and they are living longer, so household incomes will have to support a growing number of elderly dependents. Finally, workers may be more inclined to take occupational risks and make more risky entrepreneurial investments if they can be assured that they will have some level of income in old age and will be protected from poverty.

63. As elsewhere in the world, contributory schemes such as the SSS face particular challenges in covering workers that have low and intermittent incomes, regardless of whether or not contributions are mandatory as they are for most workers in the Philippines. Informal workers generally have low and intermittent incomes and therefore face severe constraints in setting aside savings or social security contributions. They also often have needs (e.g., education of children, investment in self-employment or building a house), as well as face risks that may have greater relative importance for savings than smoothing income in retirement. In addition, the delivery system and collections channels may be inaccessible or inefficient, posing important transactions costs.

64. Given the high degree of informality in the Philippines, aligning social insurance design and delivery system with the needs of informal workers will be critical to expanding coverage. The schematic diagram in Figure 20 below illustrates how generic elements of social insurance design and implementation can be aligned with the needs of informal workers. The diagram shows how savings and social insurance policies and programs can build upon common foundations of identification and delivery systems. Moreover, it points out how micro-savings, social insurance, and health insurance programs can have important synergies in providing risk protection for informal sector workers.

65. This analysis has identified several interventions that could help improve workers coverage in the Philippines. These interventions, which are discussed in greater detail below, include:

- Strengthening the unique identification system across institutions;

- Improving the platform for delivery (including collections, data management, and payments);

- Making it easier and more efficient to save by strengthening the efficiency and coverage of savings instruments; and

- Establishing an SSS instrument to better suit the needs of informal sector workers. 
Figure 20: $\quad$ Stylized Diagram of Building Blocks for Savings and Social Insurance Aligned with the Needs of Informal Workers

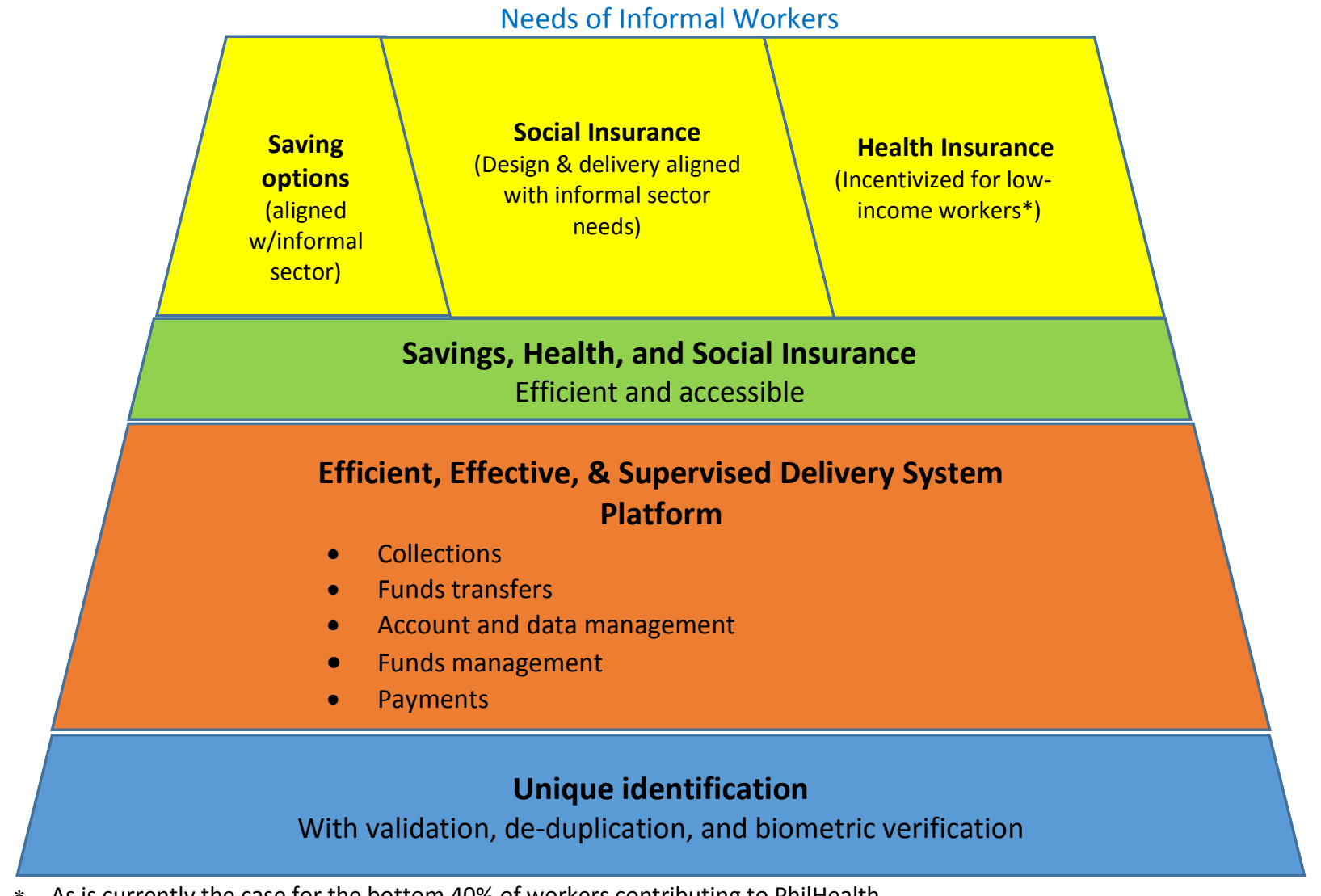

* As is currently the case for the bottom $40 \%$ of workers contributing to PhilHealth.

\section{B. SSS Measures to Increase Coverage}

66. Measures to improve SSS program administration could make it easier and more efficient for informal workers to contribute toward social security. As discussed, the SSS has already taken steps in this direction, for example with the adoption of Automatic Debt Arrangements to facilitate informal worker contributions. Furthermore, the SSS has worked through intermediaries to extend outreach and manage some of the record-keeping in the Alkansssya program. Further measures can be taken to substantially increase access through mobile-money based contributions and payments and mobile phone based member interface.

67. The identification and management information systems at the SSS can be important building blocks to the inter-institutional delivery platform indicated in Figure 20 above and discussed further in the section below. Although a more thorough assessment is needed, in principle, it would be possible to build upon the de-duplication capability of the SSS unified multi-purpose identification card (UMID). The de-duplication capability is a substantial asset that could, in principle, be leveraged to create a more unified identity across institutions including so that this ID could serve as a foundational identification.

68. The defined-benefit design of the current SSS scheme may not provide sufficient simplicity and flexibility for informal sector workers (farmers, self-employed, etc.) who have irregular wages and large income fluctuations. The social security instrument offered by the SSS to workers without permanent employment contracts is for the most part identical to the design and parameters offered to 
workers with contracts. One exception is that members of the AlkanSSSya scheme can make contributions according to their own schedule, and the minimum monthly covered salary of PHP 1,000 is waived. Members are also entitled to personal and housing loans the same way other workers are. Yet the 10 year vesting requirement effectively excludes some workers with short work histories from participating. Finally, although workers under the AlkanSSSya scheme are not subject to minimum contributions, they still benefit from minimum pensions. Although this technical issue has yet to become a big concern, it does suggest a need to consider an instrument more focused on informal worker characteristics.

69. The SSS might want to consider introducing a special instrument for informal workers which is designed to align with their needs and preferences. Such an instrument could be structured as a defined-contribution savings vehicle that also offers annuitized benefits at retirement. Such benefits could be additive to benefits received from the defined-benefit SSS pensions. Pension calculators could communicate projected benefit levels at different retirement ages, including benefits for workers with contributions in both the defined-contribution and defined-benefit SSS schemes. Moreover, partial withdrawals could be permitted in the case of defined events such as extended unemployment, catastrophic health events or disability and natural disasters. Finally contributions should be voluntary and at the level and timing appropriate to each worker (such as the approach with the AlkanSSSya program. Together, these features could make such an SSS instrument more attractive than the current defined-benefit SSS instrument for informal workers.

70. One reason for considering making a new SSS instrument voluntary is that enforcement of mandatory contributions from informal sector workers has proven to be costly and largely ineffective in the Philippines and in many countries worldwide. The manpower required to scrutinize the financial reporting of small firms and the self-employed effectively is substantial so many countries have sought other means of improving collections such as merging income tax and social security payroll tax collections and using the different incentives of each to assist in identifying evasion. Many countries link business licensing to tax and social security and some have established mechanisms for linking social security payroll taxes to sub-contracting services to firms or individuals.

71. Although several countries have considered matching contribution subsidies to expand coverage, our analysis suggests that this would not be the most effective instrument for coverage expansion in the Philippines as follows: (i) those poor and vulnerable workers who could access the subsidy are unlikely to be able to afford the contribution; and (ii) the fiscal costs could be substantial depending on the benefit level, match and targeting. A more effective alternative would be to use fiscal resources to broaden the scope of beneficiaries who are eligible for social pensions as discussed in the section below. Over the long-term, with income growth, it may be constructive to revisit the costeffectiveness of such matching contributions (Additional international experience with matching contribution subsidies is provided in Box 2 below). 


\section{Box 2: Matching Contribution Programs to Extend Social Security Coverage}

Korea. Korea gradually extended mandatory contributions to its National Pension Scheme (NPS) to all rural residents in 1995 and to the entire working population in 1999 (See Figure ${ }^{*}$ ). Although contributions are required, more than a third of workers have not been contributing. A majority of these have been poor or low-income workers with insecure employment, such as temporary workers, the self-employed, and small business owners. In 2005 contribution subsidies were offered by the government to farmers and fishers for $50 \%$ of the total contribution amount up to a cap, and a fixed amount over that. An evaluation found that the probability of contributing to the national pension system was more than 10 percentage points higher among (subsidized) farmers and fishers than among nonsubsidized self-employed workers. A reform program in 2007 included measures aimed to extend coverage with the introduction of a non-contributory Basic Old-Age Pension which provides a benefit equivalent to 5 percent of the average monthly income of NPS participants paid to those aged 65 or over whose income level is lower than a specified threshold. Although coverage has increased substantially during the NPS history, the matching contribution scheme has been one of many factors contributing to the increase.

\section{Figure *: Coverage of Korea's National Pension System, 1988-2009}

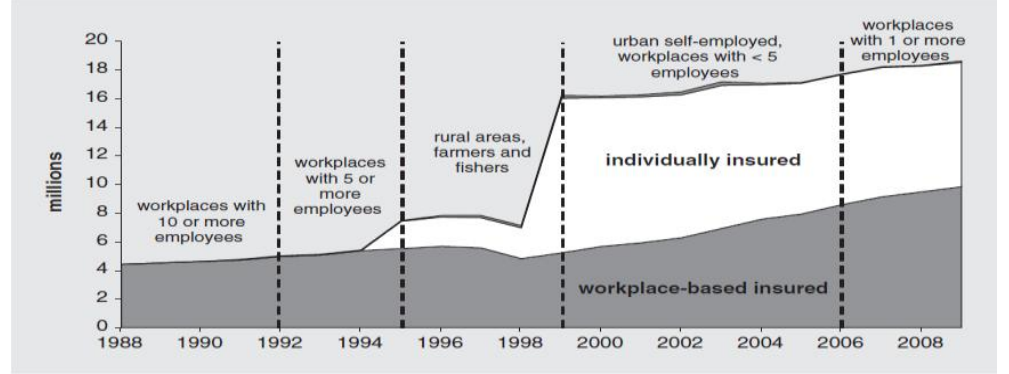

Source: National Pension Service website (http://english.nps.or.kr).

Mexico. The Social Contribution scheme is one of Mexico's matching-type schemes that targets low-wage workers as part of the defined contribution scheme administered by the Mexican Social Security Institute. The value of the matching contribution is progressive, decreasing by steps with multiples of the minimum wage. The Social Contribution significantly increases the retirement savings of lower-income workers. In 2009, the federal government limited payment of the Social Contribution to workers who earned less than 15 times the minimum wage. One finding of an assessment of schemes in Colombia, Peru and Mexico was that the matching schemes do not seem attractive enough to people who are not contributing to existing pension schemes or who are not even affiliated.

Chile. Chile in 2008 introduced at matching contribution of $15 \%$ of voluntary pension savings up to $\$ 470$ per year for those workers who do not take advantage of tax benefits. Two subsidies for pension contributions were also introduced for young workers in 2008 and 2011, respectively, targeting the bottom $40 \%$ of the population. These contributions aimed to encourage formal employment while also improving low pension balances. Matching contribution subsidies were available for 24 months. All of these were in addition to the establishment of an ex post solidarity pension pillar targeted at the retirees in the bottom $60 \%$ of welfare distribution. An evaluation of the matching subsidies suggest that they may be positive for employment and labor force participation in the short term but are unlikely to provide a meaningful alternative to the solidarity pillar in addressing low pensions.

India. In 2010, the government of India established a matching contribution of Rs. 1,000 a year to be deposited into New Pension Scheme accounts for individuals making contributions between Rs. 1,000 and 12,000 per year (NPS-lite). The fees for basic retirement savings accounts were low. In addition, "aggregators" were provided incentives to motivate informal sector enrollment. Although an evaluation was undertaken very soon after the program's introduction, some of the initial findings were that the experience with the scheme have been mixed. Participation has been limited. The so-called unorganized sector was found to be very heterogeneous with a broad income distribution and individuals of all ages and education levels. The limited analysis of a sample suggest that women are more likely to participate than men, higher income and more education are positively associated with take-up, and having other potential sources of income for old age reduces take-up.

\section{Sources:}

1. Carranza, Luis; Angel Melguizo, and David Tuesta, 2013. "Colombia, Mexico, and Peru: Experiences and Prospects," in Matching Contributions for Pensions, World Bank.

2. Moon, Hyungpyo, 2013. "Matching Contributions and Compliance in Korea's National Pension Program," Chapter 8 in Matching Contributions for Pensions, World Bank.

3. Palacios, Robert; and Renuka Sane, 2013. "Learning from the Early Experience of India's Matching Defined Contribution Scheme," in Matching Contributions for Pensions, World Bank.

4. Von Gersdorff, Hermann, and Paula Benavides, 2013. "Complementing Chile's Pensions with Subsidized Youth Employment and Contributions," in in Matching Contributions for Pensions, World Bank. 
72. Preliminary calculations suggest that worker contributions would be unaffordable for those in the bottom 4 deciles even when the target benefit is only a poverty line income. We calculated possible level of a matching grant by evaluating the cost and matching subsidy necessary to achieve an individual income at retirement equal to the current individual poverty line. The calculations suggest that a 1:1 matching contribution of about PHP 2,900 per year per individual could achieve a target of a poverty line income at age $65 .{ }^{40}$ We also examined which individuals across the income spectrum would likely be able to afford such a contribution. As Figure 21 illustrates, all of those in the bottom 4 deciles are highly unlikely to be able to afford such a contribution. Even those in the $5^{\text {th }}$ decile would have to dedicate more than one-fifth of their savings (net income after expenditures) to contributions to such a social security scheme, and those in the $4^{\text {th }}$ decile would have to dedicate about one-third.

Figure 21: Average Income, Expenditure, and Savings of Families by Decile and Minimum Pension Contribution as Percentage of Savings

('000 pesos left axis, \% right axis)

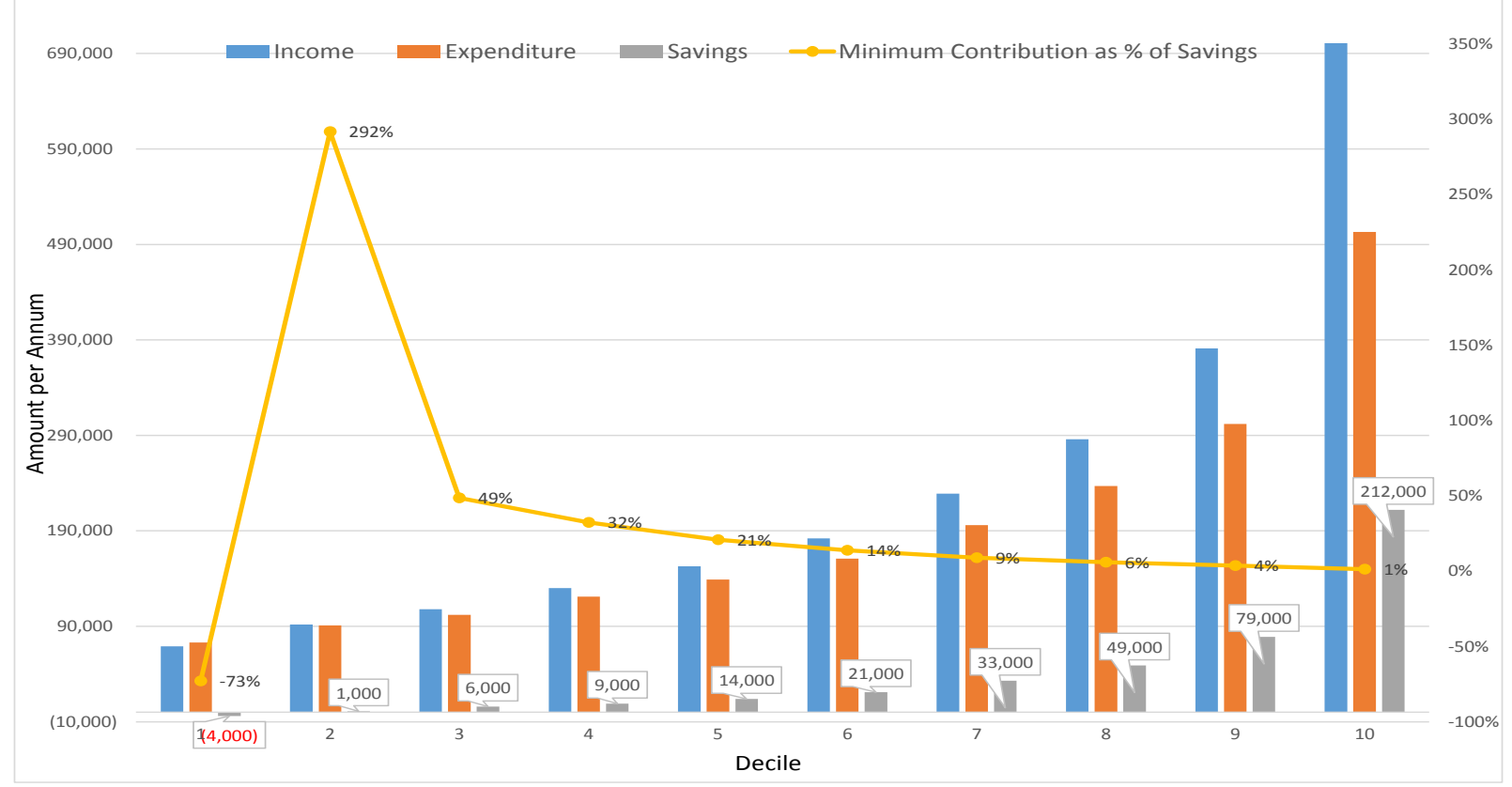

Source: National Statistics Office, 2012 Family Income and Expenditure Survey Final Results.

73. Matching contribution subsidies are quite costly from a fiscal perspective, raising questions as to their affordability and sustainability. An initial assessment suggests that the annual cost of achieving a benefit that aims to achieve a pension benefit at the current individual poverty threshold and targeted at the bottom $40 \%$ of the labor force could cost as much as 0.6 percent of GDP. Such a cost would need to be sustained for an entire generation to build up the balances to achieve the desired benefits. When

\footnotetext{
${ }^{40}$ Key determinants of the cost are: (a) those eligible to receive the matching subsidy; (b) the amount of the contribution; (c) the ratio between the individual contribution and the matching subsidy; and (d) the expected rate of take-up. The following assumptions were used in this calculation: (i) the target benefit level was PHP 21,072 per year, which is the national annual poverty threshold per capita $\left(1^{\text {st }}\right.$ semester, 2014); (ii) the matching grant was assumed to be 100 percent of the worker contribution; (iii) the funds were assumed to yield a 3-percent real rate of return; (iv) the annual contributions and matching grants were assumed to grow at a rate of 3 percent per year; (v) the real discount rate was 3 percent; (vi) workers were assumed to contribute for 25 years, immediately prior to retirement at age 65; and (vii) the future unisex life expectancy was assumed to be 14.5 years at age 65 , the same as in 2015 for the entire population.
} 
measured against the total level of Government revenues, this represents an important expenditure that would need to be assessed in terms of its cost effectiveness and weighed against the potential outcomes from other public expenditures.

\section{Beyond SSS - Inter-Institutional Delivery System, Savings Options, and Broadening Eligibility for Social Pensions}

74. Many of the processes outlined in the building blocks in Figure 20 above are common across institutions. In this way, a de-duplicated foundational identification has applications that extend well beyond Social Security and can be equally effective in strengthening Government transfer programs, PhilHealth and can assist in broadening public access to financial intermediation such as through bank or mobile-money accounts. Similarly, an efficient and effective payment system can reduce the cost of the extensive money transfers in the Philippines as well as facilitate contributions from and payments to the vast majority of Filipino population including those living in remote locations. A platform that can easily and cheaply ensure secure contributions and disbursements can materially reduce the time and cost necessary for routine transactions. Mobile-based communications can contribute towards achieve such efficiency though needs to be effectively regulated to ensure secure transactions. Together these processes can be referred to as a delivery system platform.

75. SSS operations could build upon such an inter-institutional platform to provide efficient and secure coverage for its members, including those in the informal sector. For example, if the current deposits by AlkanSSSya members could be deposited by phone instead of through the savings boxes, it may be possible to substantially scale-up the AlkanSSSya membership.

76. Further work is also needed to establish mobile money platforms that can support (i) mobilephone-based remittances from different sources including bank accounts, ATMs, or shops offering money transfer services; (ii) mobile-phone-based account payments or withdrawals; and (iii) phone- or internet-based information inquiries on account balances and entitlements. Mobile money platforms could reduce transaction costs for informal worker participation in social security schemes, improve efficiency for payments and money transfers, and generally remove barriers to savings opportunities for heretofore unbanked individuals and businesses. However, only about 4 percent had mobile money accounts in $2014^{41}$ and anecdotal information suggests that the use of mobile money platforms for collections, funds transfers, and payments is very limited.

\section{Expanding access to savings can reinforce the agenda of increasing coverage. Savings} accounts can play an important role in helping workers save for multiple social risks such as loss of employment, health risks, disability, and old age. Moreover, informal workers can be assured of withdrawing their funds when needed. The Philippines has relatively low levels of financial inclusion and very low levels of mobile-money access all of which can be useful for informal workers. About one-third of the population over age 15 had bank accounts in 2014 (versus 69 percent for the EAP region), while only about 15 percent had formal savings (versus 36 percent for the EAP region), and only about 4

\footnotetext{
${ }^{41}$ See World Bank, Financial Inclusion Data, Global Findex, accessed May 2016. http://datatopics.worldbank.org/financialinclusion/country/philippines.
} 
percent had mobile money accounts. ${ }^{42}$ The authorities are aware of this and are taking steps aimed at improving financial inclusion.

78. Voluntary pension arrangements can play a role in the Philippines in supplementing SSS benefits as well as in improving coverage. Supplementary contractual savings arrangements are a means by which employers can create incentives for staff retention. A regulated program such as the Private Employee Retirement Accounts (PERA) can provide a vehicle for retirement savings by selfemployed professionals if SSS contributions are insufficient.

79. The DSWD Social Pension plays an important role in ensuring the basic livelihoods of the poorest elderly and broadening its target population (if fiscally manageable) would prove more effective in increasing coverage of the elderly when compared with matching grants. The Listahanan national household targeting system could be used as a basis for broadening the eligibility for the Social Pension from the current poor in the bottom two deciles to possibly the poor and near-poor by raising the household eligibility threshold possibly to the bottom four deciles. This would mean that those eligible households in the bottom 40 percent with elderly members over age 65 could qualify for a Social Pension benefit, much in the same way that the same households can qualify for PhilHealth benefits. This would have an immediate impact while the matching grant would take many years to mature.

80. Although the design, benefit level, qualifying criteria, and targeting method appear to be strong, measures which could be considered to further strengthen the Social Pension include: (i) providing automatic annual increases in the benefit linked to the growth in consumer prices to ensure that the benefit maintains its purchasing power; (ii) conducting periodic program assessments to review targeting outcomes and identify any inclusion and exclusion errors (and devise a strategy to address such errors as needed), ${ }^{43}$ as well as to measure the impact on elderly poverty; and (iii) conducting periodic reviews of the benefit amount against the individual income gap and poverty threshold, as well as relation to other social protection programs, to evaluate the design and adequacy of benefits.

81. The Philippine proposal suggested in 2015 to reduce the eligibility age to 60 would have the advantage of aligning the eligibility age with that of the eligibility age for the SSS and GSIS, but the tradeoffs and impacts need to be considered carefully. The same fiscal resources needed in reducing the eligibility age could instead be used to increase the scope of old age beneficiaries proposed or, alternatively, could be earmarked to increase public transfers to other programs such as the Conditional Cash Transfer program targeted at poor children. It should also be noted that those elderly ages 60-64 have substantially higher wage incomes and higher labor force participation rates than those age 65 and above. As a result, reducing the eligibility age to 60 years may somewhat deter the incentives to work for some beneficiaries, although it is important to note that eligible beneficiaries would be from poor households.

\footnotetext{
42 Ibid.

${ }^{43}$ Data-based evidence on the targeting performance of Social Pensions could not be provided, as the household survey does not have a specific question about the receipt of a Social Pension.
} 


\section{Conclusion}

82. Going forward, additional diagnostic work will be needed to inform the design of specific strategies for improving the coverage and sustainability of social security in the Philippines. For example, a diagnostic evaluation is needed to identify weaknesses in the identification and SSS operations and delivery system, particularly with regard to low-income, informal workers. Contributory pension design options and parameters need to be considered which better align the incentives toward coverage expansion. Beyond the SSS, barriers to savings need to be studied and addressed. Finally, PROST simulations could be supplemented by simulations using additional parameters which may have not yet been considered.

83. This report has looked at some reform options to help the SSS improve sustainability, provide greater incentives to participate, and improve inflation risk coverage. A gradual process of parametric reforms is proposed which does not abruptly or adversely affect existing retirees or workers approaching retirement age. Moreover, it is suggested to weigh the tradeoffs between the objectives of coverage expansion and the potential adverse effect of increases in the contribution rate. Fortunately, the analysis suggests that the SSS scheme can achieve long-term sustainability on a gradual basis with modest changes in the qualifying conditions, benefits, and, possibly the contribution rate.

84. This report has also suggested options to strengthen social security coverage, particularly of informal workers. Several measures were proposed including further strengthening the mechanisms for contributions, account access and payments, and introducing a new SSS savings instrument aligned to the needs of informal sector workers. An assessment of matching contribution subsidies to expand coverage suggested that a more effective alternative would be to broaden the scope of beneficiaries eligible for social pensions.

85. Beyond the scope of the SSS, additional measures were looked at to strengthen the coverage of social protection for informal workers. Measures were suggested to improve the access and efficiency of contributions and payments systems, including measures mobile-money platforms; further measures to improve access to savings instruments, particularly for small savers; and some further improvements to the strong Social Pension, including broadening eligibility and automatic price indexation of benefits.

86. Improvements in SSS sustainability and the instruments and delivery systems for social security coverage comprise only one part of a broader strategy needed to better protect the vast majority of workers in the Philippines with low, intermittent and variable sources of income. A more systemic view of job creation, labor market and social insurance reforms can help to better protect these workers. Ultimately, the only sustainable approach to combating low-skill, low-wage, and lowsecurity informal jobs is to strengthen the quality of growth and job creation. Measures are needed on numerous fronts to combat the causes of informality, such as removing barriers to competition and growth in real sectors and addressing barriers to formality including taxes and labor market provisions. 


\section{References}

1. ABS-CBNnews.com (website), 2015. SSS announces UMID card release schedule, 4/15/15.

2. Aquino, Emilio B., 2002. Private Pension Schemes in the Philippines: Regulatory Practices.

3. Asher, Mukul G., 2013. Social Pensions for the Elderly in Asia: Fiscal Costs and Financing Methods, Chapter 2 in Social Protection for Older Persons: Social Pensions in Asia, ADB 2013.

4. Asher, M.G, S. Oum, F. Parulian, 2010. Social Protection in East Asia - Current State and Challenges, ERIA Research Project Report 2009, No. 9, March 2010.

5. Bangko Sentral ng Pilipinas, 2013. Report on the State of Financial Inclusion in the Philippines. Inclusive Finance Advocacy Staff, Supervision and Examination Sector.

6. Barrientos, Armando, 2012. What is the Role of Social Pensions in Asia? ADBI Working Paper Series, No. 351, April 2012.

7. Carranza, Luis; Angel Melguizo, and David Tuesta, 2013. "Colombia, Mexico, and Peru: Experiences and Prospects," in Matching Contributions for Pensions, World Bank.

8. Casals, Camilo, n.d. [2007?]. Exploratory Study of Micro-Pensions in the Philippines.

9. Commissioner of Insurance, 2015. Statistics (website), http://www.insurance.gov.ph/htm/ statistics.asp

10. De la Rama, Marie, 2009. Pension funds in a highly politicized environment: The case of the Philippines, Pensions Vol. 14, 4, 242-258, June 2009.

11. Department of Social Welfare and Development, 2015. Social Pension for Indigent Senior Citizen, Program Briefer, Mimeo Powerpoint.

12. Government of the Philippines, 2015. More Indigent Seniors to Receive Monthly Pension. Official Gazette, February 17, 2015, http://www.gov.ph/2015/02/17/more-indigent-seniors-toreceive-monthly-pension/

13. 2010. Republic Act No. 9994. Expanded Senior Citizens Act of 2010.

14. Government Service Insurance System, 2015. Premium Payments (website), http://www.gsis.gov.ph/default.Php?id=86

15. ,2015. Ecard plus as utility card (website)

http://www.gsis.gov.ph/default.PHP?id=53

16. 2015. Retirement Programs (website)

http://www.gsis.gov.ph/default.PHP?id=33

17. 1997. Republic Act No. 8291. http://www.gsis.gov.ph/default.PHP?id=111

18. Hinz, R., R. Holzmann, D. Tuesta and N. Takayama, eds., 2013. Matching Contributions for Pensions: A Review of International Experience. The World Bank, 2013.

19. IMF, 2014. Philippines, 2014 Article IV Consultation, Staff Report, Press Release.

20. Inquirer.net, 2013. Only 20 preneed firms remain out of 200 plus, http://newsinfo.inquirer.net/489799/only-20-preneed-firms-remain-out-of-200plus\#ixzz3pJp5Jq6J

21. Manasan, Rosario G, 2009. "A Review of Social Insurance in the Philippines," Philippine Journal of Development, Number 67 Second Semester, 2009.

22. Meißner, Matthias, 2014. Old age protection for informal workers-feasible or too far away?, GIZ Discussion Papers on Social Protection, No. 20, March, 2014.

23. Mesa-Lago, C., Viajar, V.D, Castillo, RCJ, 2011. Pensions in the Philippines: Challenges and Ways Forward, Friedrich Ebert Stiftung, 2011.

24. Moon, Hyungpyo, 2013. "Matching Contributions and Compliance in Korea's National Pension Program," Chapter 8 in Matching Contributions for Pensions, World Bank.

25. OECD \& World Bank, 2013. Pensions at a Glance, East Asia and Pacific, OECD, 2013. 
26. Orbeta, Aniceto C. Jr., 2010. Social Protection in the Philippines: Current State and Challenges, Chapter 8 in Social Protection in East Asia - Current State and Challenges, ERIA Research Project Report 2009, No. 9.

27. Palacios, Robert; and Renuka Sane, 2013. "Learning from the Early Experience of India's Matching Defined Contribution Scheme," in Matching Contributions for Pensions, World Bank.

28. Palacios, Robert, 2014. Pensions in Aging East Asia, Draft Mimeo, World Bank, November 2014.

29. Park, Donghyun, ed., 2012. Pension Systems and Old-Age Income Support in East and Southeast Asia: Overview and Reform Directions, Asian Development Bank.

30. Pizaña, Aileen Grace P., 2014. Tax exemptions on retirement plans: Revalidated and clarified, The Philippine Star, January 14, 2014, http://www.philstar.com/business/2014/01/14/1278487/tax-exemptions-retirement-plansrevalidated-and-clarified

31. Racelis, Rachel H., M. R. Abrigo, J.M. Salas, A.N. Herrin, 2015. Philippines 2011 National Transfer Accounts Estimates of Consumption and Labor Income Age Profiles, Philippine Institute for Development Studies, Discussion Paper Series No. 2012-31, October 2015.

32. Racelis, Rachel H., M. R. Abrigo, J.M. Salas, 2012. Filipino Elderly Living Arrangements, Work Activity, and Labor Income as Old-Age Support, Philippine Institute for Development Studies, Discussion Paper Series No. 2015-45, October 2015.

33. Rutkowski, Jan, 2015. Employment and Poverty in the Philippines: Philippine Labor Market Review, January 2016.

34. Social Security System, 2015. Facts and Figures as of March 2015.

$35 . \quad$ 2015. SSS launches thru-the-web issuance of social security (website announcement) https://www.sss.gov.ph/sss/appmanager/viewArticle.jsp?page=NR2015 097

36. 2014. 2013 Annual Report.

37. 2013, Actuarial Valuation.

38. 2004. Actuarial Study Notes, SSS Actuarial Department, October, 2004.

39. Tiongson, Randell, 2015. All About PERA, Business Inquirer.net. September 2, 2015. http://business.inquirer.net/198300/all-about-pera

40. Von Gersdorff, Hermann, and Paula Benavides, 2013. "Complementing Chile's Pensions with Subsidized Youth Employment and Contributions," in in Matching Contributions for Pensions, World Bank.

41. Weber, Axel, 2012. Assessment of the Philippine Social Protection Floor Policies, Brot fur die Welt, June 2012.

42. World Bank, 2016. Employment and Poverty in the Philippines, January 22, 2016.

43. _ 2015. World Economic Indicators (accessed via website, 2015), http://data.worldbank.org .

44. 2015. Philippine Identification System Analysis Report, Draft Mimeo.

45. 2015. Enhancing Financial Capability and Inclusion in the Philippines - A

46. 2013. Philippine Development Report: Creating More and Better Jobs, World Bank Philippine Office, East Asia and Pacific Region.

47. World Health Organization, 2011. Life Expectancy at Different Ages, in http://www.worldlifeexpectancy.org, accessed 2015. 


\section{Annex 1: Main Assumptions used in PROST Projections}

Financial projections for the SSS of the Philippines were conducted with the World Bank's Pension Reform Options Simulation Toolkit (PROST) model. The simulation period runs from 2013 to 2080. The main assumptions used in the projections are described below.

\section{Demographic assumptions}

UN population data and demographic projections for the Philippines were used as the basis for assumptions about future changes in fertility and mortality rates as follows:

- Mortality at all ages was expected to decline over the projection period consistent with expectations in countries of similar levels of development, resulting in projected life expectancies as shown in Table 11;

- Life expectancy of the covered population mirrored the life expectancy of the general population; and

- Fertility was assumed to decline gradually from the current level of 2.94 births per adult female to the replacement level of 1.85 births by 2080 .

\section{Table 11: $\quad$ Life Expectancy at Various Ages by Gender}

\begin{tabular}{|l|r|r|r|r|}
\hline & \multicolumn{1}{|c|}{$\mathbf{2 0 1 3}$} & \multicolumn{1}{|c|}{$\mathbf{2 0 3 0}$} & \multicolumn{1}{c|}{$\mathbf{2 0 5 0}$} & $\mathbf{2 0 8 0}$ \\
\hline Male & & & & \\
Life Expectancy: At Birth & 66.2 & 70.2 & 74.0 & 77.9 \\
$\quad$ At Age 20 & 49.0 & 52.4 & 55.8 & 59.3 \\
$\quad$ At Age 60 (retirement age) & 15.9 & 18.1 & 20.3 & 22.7 \\
$\quad$ At Age 65 & 12.9 & 14.7 & 16.6 & 18.8 \\
Female & & & & \\
Life Expectancy: At Birth & 72.7 & 76.2 & 79.6 & 83.2 \\
$\quad$ At Age 20 & 54.9 & 57.9 & 60.8 & 64.1 \\
$\quad$ At Age 60 (retirement age) & 19.0 & 21.1 & 23.3 & 25.8 \\
$\quad$ At Age 65 & 15.2 & 17.1 & 19.0 & 21.3 \\
\hline \multicolumn{2}{|l}{} \\
\hline
\end{tabular}

Macroeconomic assumptions

The following macroeconomic assumptions, summarized in Table 12 below, were used:

- The assumptions for GDP growth and inflation rates for the period of 2015-2019 were based on the IMF macroeconomic projections for the Philippines (Article IV, August 2014);

- In the long run, GDP growth rates were calibrated to maintain a fairly constant ratio of labor income to GDP;

- The long run inflation rate was assumed to stabilize at 3.5 percent; and

- Real wages/earnings were assumed to grow at about 2 percent. 
Table 12: Macroeconomic Assumptions Used in PROST Projections

\begin{tabular}{|l|c|c|c|c|c|c|c|c|}
\hline & $\mathbf{2 0 1 4}$ & $\mathbf{2 0 1 5}$ & $\mathbf{2 0 1 6}$ & $\mathbf{2 0 1 7}$ & $\mathbf{2 0 1 8}$ & $\mathbf{2 0 1 9}$ & $\mathbf{2 0 4 0}$ & $\mathbf{2 0 8 0}$ \\
\hline Nominal GDP growth rate & $10.5 \%$ & $10.6 \%$ & $9.9 \%$ & $9.7 \%$ & $9.7 \%$ & $9.8 \%$ & $6.6 \%$ & $5.6 \%$ \\
\hline CPI (annual average) & $4.4 \%$ & $3.8 \%$ & $3.5 \%$ & $3.5 \%$ & $3.5 \%$ & $3.5 \%$ & $3.5 \%$ & $3.5 \%$ \\
\hline Average annual nominal wage growth rate & $6.5 \%$ & $5.9 \%$ & $5.6 \%$ & $5.6 \%$ & $5.6 \%$ & $5.6 \%$ & $5.6 \%$ & $5.6 \%$ \\
\hline
\end{tabular}

$\underline{\text { Pension policy and member behaviour }}$

- A conservative assumption was used with respect to contributor coverage rate: age-specific coverage rates (number of contributors as percentage of population in respective age and gender groups) were assumed to remain constant throughout the projection period;

- Contribution density was assumed to remain constant over the whole projection period;

- The ratio of the contribution ceiling to average earnings of contributors was assumed to remain constant over the projection period;

- Pattern of retirement by age was assumed to remain consistent with the current experience;

- The ratio of short-term benefits to total benefit payments was assumed to remain at current levels of about 10 percent;

- The ratio of administrative expenses to total contributions was assumed to continue to decrease in line with the current trend over the next five years (from 7.5 percent in 2013 to 5 percent by 2018) then stabilize and remain at 5 percent over the rest of the projection period;

- Indexation policy for post-retirement pensions in the base case (no-reform) scenario assumed 60 percent of inflation starting from 2016 (in line with the average annual growth rate over the last 15 years);

- The nominal value of the minimum pension was assumed to remain constant at PHP 1,200 and PHP 2,400 (for less than 20 years of contributions and for 20 and more years of contributions, respectively); and

- The nominal values of the supplemental allowance of PHP 500 for disability pensioners and the flat amount of PHP 300 in the formula for calculating retirement benefits were assumed to remain the same, in line with the current policy to phase them out gradually. 


\section{Annex 2: General Description of PROST Methodology}

PROST is a computer-based pension model designed to simulate the behavior of pension systems and assess their financial sustainability under different economic and demographic assumptions over a long timeframe. The model can be adapted to a wide range of country circumstances and allows modelling of various types of pension reform options.

The model consists of an input workbook and five output modules. On the input side, the user provides country-specific data on demographic, economic, and pension-system-related parameters and assumptions about their behavior in the future. This information is entered in the input file with six embedded worksheets:

General Economic variables (GDP and wage growth, inflation, interest rate), non-age-
specific pension system parameters (pension fund balance and benefit
expenditure in the base year, retirement age, contribution rate, pension
indexation rules, etc.), and some demographic variables

Population Base-year population by age and gender along with age-specific fertility and mortality rates and immigration information

Labor Age- and gender-specific labor force participation and unemployment rates as well as distribution of wages and old age pensions across age and gender cohorts

Pension Age- and gender-specific information about pension system contributors, beneficiaries, coverage and retirement rates, average years of service at retirement, and replacement rates for new beneficiaries

Profiles Information on representative individuals, such as gender, career path, individual wage, life expectancy, etc.

Reform Parameters relevant to systemic reforms to be simulated (any combination of conventional PAYG, fully funded DC, and NDC pillars), including switching pattern, how the acquired rights will be paid, contribution rates, rules for annuitization and pension pay-out under DC schemes, replacement rates/benefit formula in a PAYG pillar, indexation, etc.

PROST follows single age/gender cohorts over time and generates population projections which, combined with labor market assumptions, are used to forecast future numbers of contributors and beneficiaries. These in turn generate flows of revenues and expenditure. The model then projects fiscal balances and calculates the implicit pension debt. The required contribution rates and affordable replacement rates for zero pension fund balance in each year of the simulation period are also calculated. Finally, PROST produces outputs related to individuals-what an individual would contribute to the system and what he/she would obtain under PAYG DB and multi-pillar schemes. This allows both intra- and intergenerational analysis.

Depending on the characteristics of the pension system and data availability, the user can choose the method for calculating some of the variables. In particular, the number of contributors and beneficiaries can be computed in either "Stock" or "Flow" method. With the "Stock" method, the stocks of 
contributors/beneficiaries for each year are calculated first, then inflows (new contributors/beneficiaries) are derived as the changes of the stocks:

$$
\operatorname{Inflow}(a, t, g)=\operatorname{stock}(a, t, g)-\operatorname{stock}(a-1, t-1, g)+\operatorname{outflow}(a, t, g) \text {, }
$$

With the "Flow" method, inflows are calculated first, then stocks are derived as previous year's stocks in each age/gender cohort adjusted for the net inflow (inflow-outflow):

$$
\begin{gathered}
\operatorname{Stock}(a, t, g)=\operatorname{stock}(a-1, t-1, g)-\text { outflow }(a, t, g)+\operatorname{inflow}(a, t, g), \\
\text { Where } \mathrm{a}=\text { age, } \mathrm{t}=\text { year, } \mathrm{g}=\text { gender. }
\end{gathered}
$$

As PROST keeps track of contribution years of service accrued by each cohort, the calculated number of new retirees-whatever method is used-is then adjusted so that the total length of service accrued by the cohort is equal to the total length of service claimed by the cohort at the time of retirement. After the number of new retirees is adjusted, the stock is recalculated using the "Flow" method.

The user can also choose how the benefit of new beneficiaries is specified-via benefit formula or via age- and gender-specific replacement rates.

In the most simplified way, the general calculation scheme is summarized in the figure below.

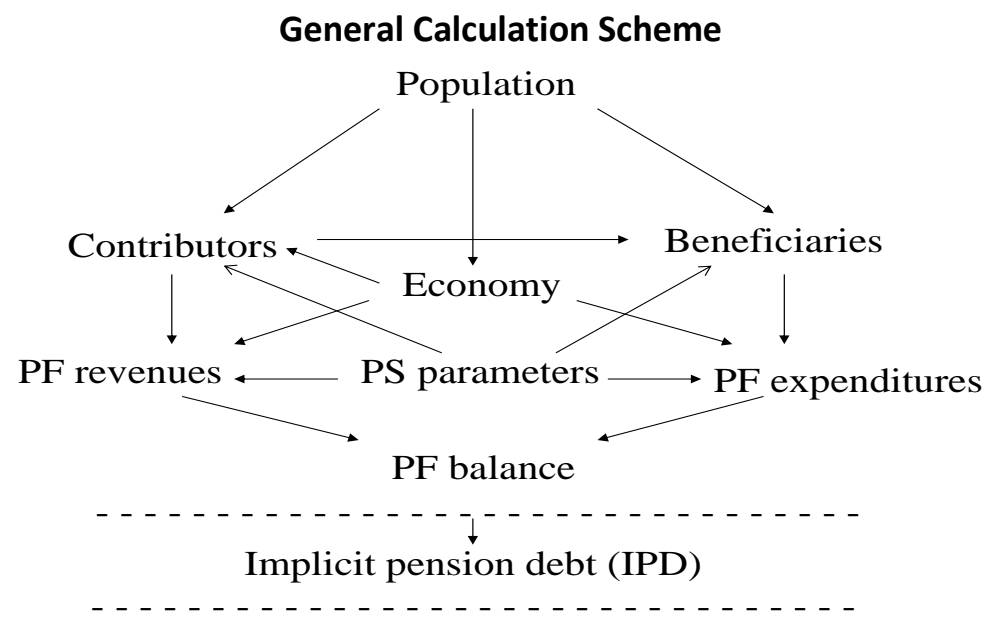

Individual accounts

As mentioned above, the output produced by PROST is organized in five output modules. Each of the modules contains a number of Excel worksheets and a graphical summary of key output indicators:

Population Projection

Demographic Structure

Finances of Single-Pillar PAYG
Population projections and pyramids, life tables, life expectancy changes, population dependency rates, etc.

Labor force and employment projections, projections of contributors and beneficiaries, demographic structure of the pension system, and system dependency rates

Macroeconomic trends, wage projections, pension benefit projections for existing and new pensioners, revenue and expenditure of the pension system, required adjustments to 
contribution rates and replacement rates for zero current balance, and implicit pension debt

Finances of Multi-Pillar System

Individual Accounts
Pension benefit projections for new and existing pensioners under each of the three pillars (conventional PAYG, notional PAYG, and funded DC), revenues and expenditures of both PAYG and funded pillars, implicit pension debt of the PAYG system after the reform, and results of the reform (compares benefit projections and financial standing under the single-pillar PAYG and multi-pillar scenarios)

Lifetime contributions and benefits and individual-related summary statistics for up to six different individuals specified in the "Profiles" input sheet under PAYG system (statutory, with adjusted contribution rates and adjusted benefits) and multi-pillar system (for those who switched to the multi-pillar system and those who remained in the PAYG system) 


\section{Annex 3: SSS PROST Analysis - Sensitivity Tests}

Sensitivity analysis tests were undertaken to understand the impact of changes in demographic, coverage, and return assumptions on the financing gap projected by the SSS PROST projections. In addition, sensitivity tests were undertaken for the policy variable of the assumption of the cap on wages used to determine contributions and benefits. A summary of the results is provided in Table 13.

Table 13: $\quad$ SSS - Sensitivity Tests

\begin{tabular}{|l|c|c|c|}
\hline \multicolumn{1}{|c|}{ Sensitivity tests } & Financing gap* & Break-even point** & Assets depletion point*** \\
\hline Baseline & $(34 \%)$ & 2036 & 2044 \\
\hline test 1 & $(36 \%)$ & 2035 & 2043 \\
\hline test 2 & $(43 \%)$ & 2039 & 2047 \\
\hline test 3 & $(15 \%)$ & 2027 & 2036 \\
\hline test 4 & $(17 \%)$ & 2029 & 2038 \\
\hline test 5a & $(57 \%)$ & 2034 & 2042 \\
\hline test 5b & $(20 \%)$ & 2038 & 2046 \\
\hline
\end{tabular}

* \% of 2013 GDP, with $4 \%$ real discount rate

** Year when the annual current balance turns negative

*** Year when Pension Fund's own assets are depleted and government needs to step in to cover deficits

Sensitivity Test 1: life expectancy at age 60 for covered assumed to be 2 years higher than for the general population Sensitivity Test 2: coverage assumed to roughly double by $2080<--$ GDP per capita growth + age distribution of coverage rates flattens over time

Sensitivity Test 3: contribution ceiling not indexed

Sensitivity Test 4: contribution ceiling increased by PHP 200 per year

Sensitivity Test 5a: interest rate on PF investments is $3 \%$ real (1 p.p. below baseline)

Sensitivity Test $5 \mathrm{~b}$ : interest rate on PF investments is $5 \%$ real (1 p.p. above baseline)

Sensitivity Test 1: This test assumed that life expectancy for the covered population at age 60 was 2 years higher than for the general population (19.5 years versus 17.5 years) in the base year and all subsequent years. The following results were observed:

- Impact via pension system demographics: number of old age pensioners receiving pension in each year increases (shown on the dependency rate graph), the effect kicks in gradually.

- $\quad$ Average new (flow) pensions are not affected (hence there is no graph for flow replacement rates).

- Due to indexation, average stock pensions slightly decrease as people live longer.

- Increase in the number of pensioners outweighs the effect of slightly lower average pensions, so overall expenditures increase, and (with the same contributions) the annual current balance decreases.

- Overall, effect of 2-year difference is not substantial-break-even and depletion points move forward by one year, financing gap increases from 34 percent to 36 percent. 
Figure 22: $\quad$ SSS - Sensitivity Test 1: Higher Life Expectancy at Retirement-Current Balance (\% of GDP)

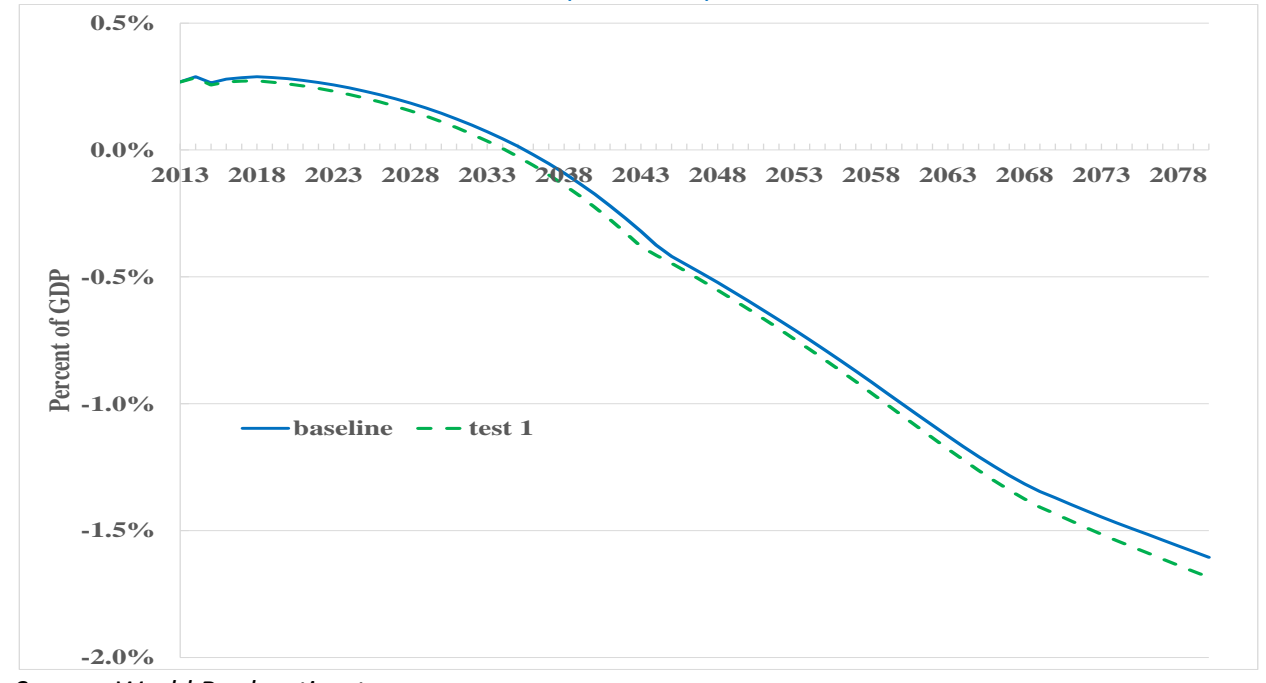

Source: World Bank estimates.

Figure 23: $\quad$ SSS - Sensitivity Test 1: Higher Life Expectancy at Retirement - Average Pension (\% of average wage)

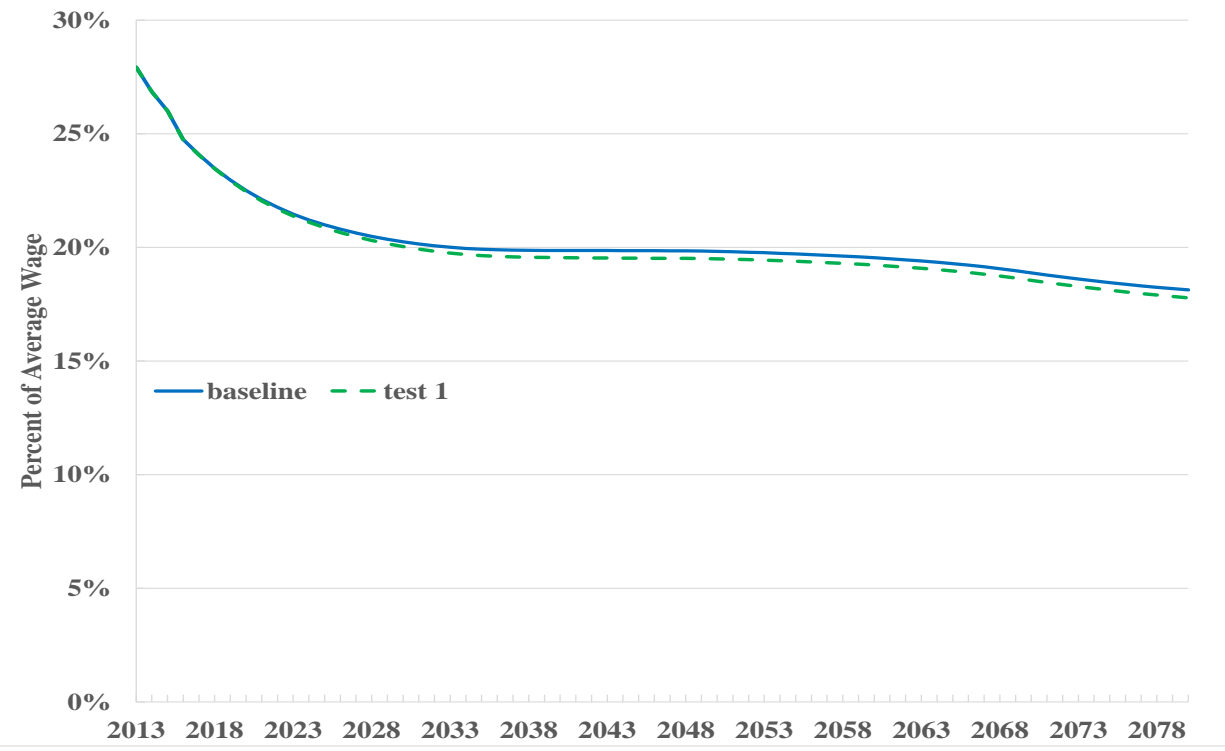

Source: World Bank estimates.

Sensitivity Test 2: Coverage was assumed to roughly double by 2080 due to economic growth and changes in wage composition of the labor force. The following was observed:

- Both the number of contributors and the number of pensioners increases, but the former starts growing immediately whereas the latter follows that increase with a lag. As a result, the system dependency rate decreases compared with the baseline.

- Average pensions-both flow and stock-practically remain the same (only some minor fluctuations of flow pensions due to age/gender/sector composition changes as well as some increases of the average full wage of the employed due to changes in their age composition).

- The impact on finances is positive in the short term (while the number of contributors starts to grow, and the number of pensioners remains about the same). In the longer run, despite a lower 
system dependency rate, deficits become higher than in the base case: although revenues roughly double by 2080 whereas expenditures increase by only about 70 percent, in absolute (money) terms, the increase in spending is significantly higher than the increase in revenues.

- Accordingly, due to the short-term positive effect on finances, both break-even and depletion points move back by three years, but the financing gap substantially increases from 34 percent to 43 percent because the long-term negative effect outweighs the short-term positive effect.

Figure 24: $\quad$ SSS - Sensitivity Test 2: Higher Coverage - Average Pension for New Retirees (\% of average wage)

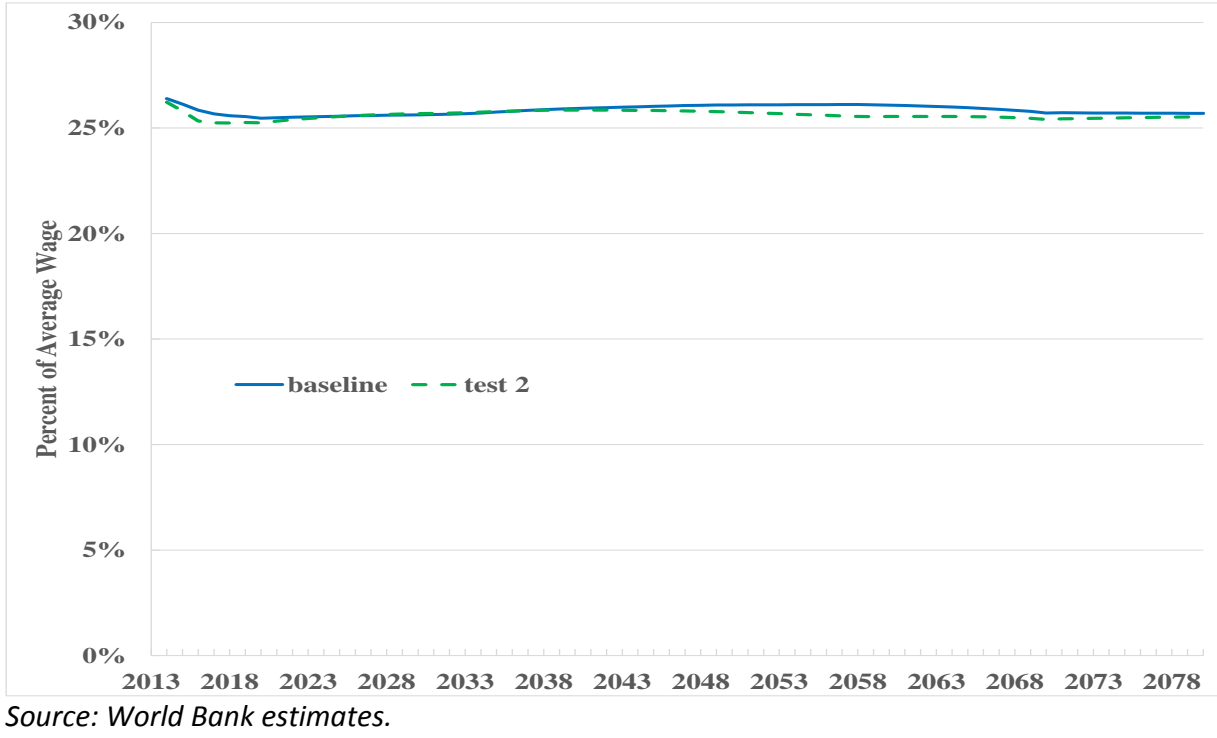

Figure 25: $\quad$ SSS - Sensitivity Test 2: Higher Coverage - Current Balance (\% of GDP)

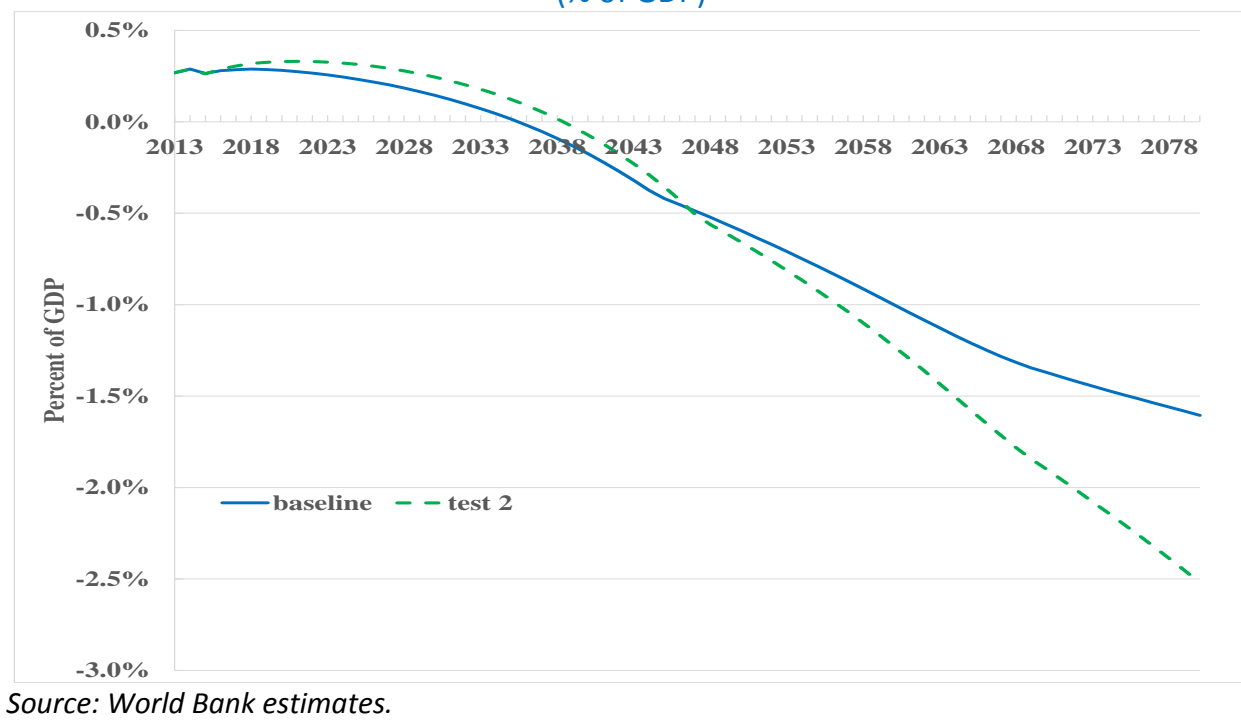

Sensitivity Test 3: This scenario illustrates the impact of not periodically raising the covered wage ceiling. The contribution ceiling remains at the same level and is not indexed. The following are the results observed:

- System demographics are not affected. 
- Pensions go down relative to average full wage as the level of the ceiling relative to full wages decreases. New (flow) pensions start decreasing immediately, whereas it takes more time for stock pensions. Stock pensions remain higher than flow pensions since most of the stock pensioners receive pensions calculated in the times of higher ceiling levels. Eventually, pension levels decrease to almost "nothing."

- In the short run, finances deteriorate because contributions decrease faster than average stock pensions. In the long run, deficits shrink because the size of the pension system (both revenues and expenditures) shrinks relative to GDP.

- Both the break-even and depletion points move forward substantially (by 9 and 8 years, respectively) due to the above short-term negative effect on finances. However, the financing gap decreases from 34 percent to 15 percent because of the shrinking of the pension system relative to GDP in the long run.

Figure 26: $\quad$ SSS - Sensitivity Test 3: Not Indexing the Contribution Ceiling - Current Balance

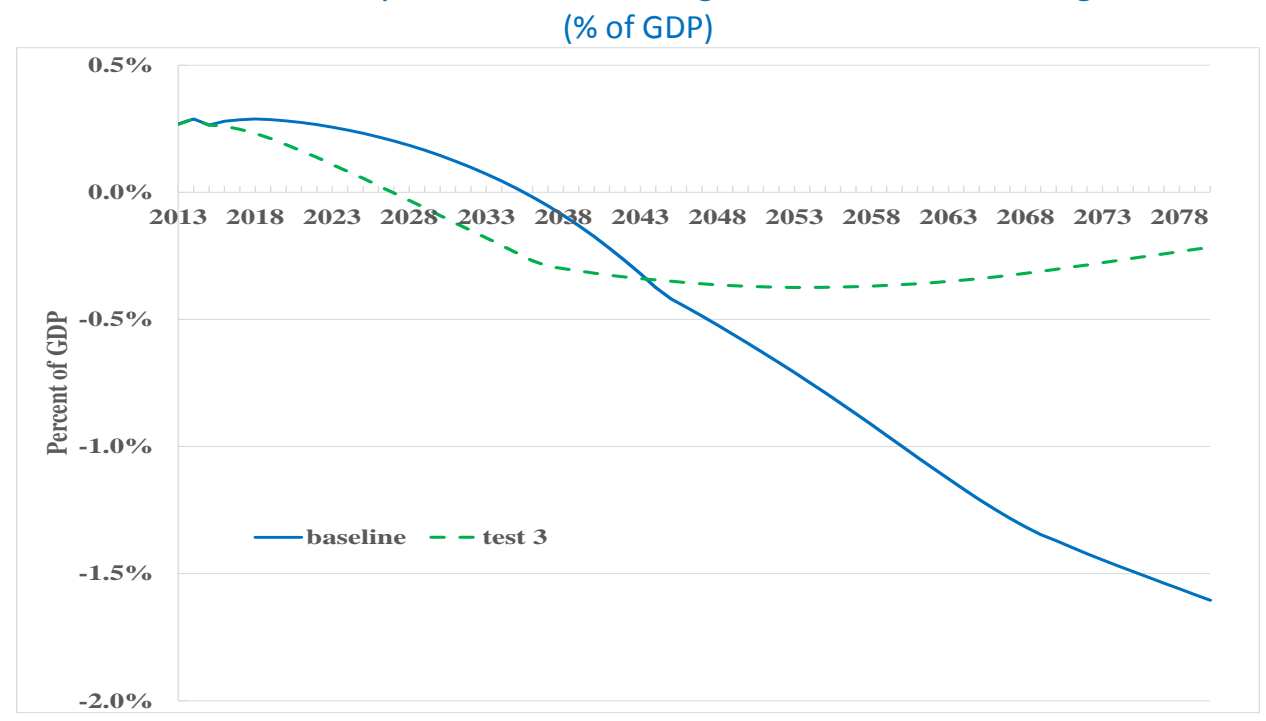

Source: World Bank estimates.

Figure 27: $\quad$ SSS - Sensitivity Test 3: Not Indexing the Contribution Ceiling - Average Pension

(\% of average wage)

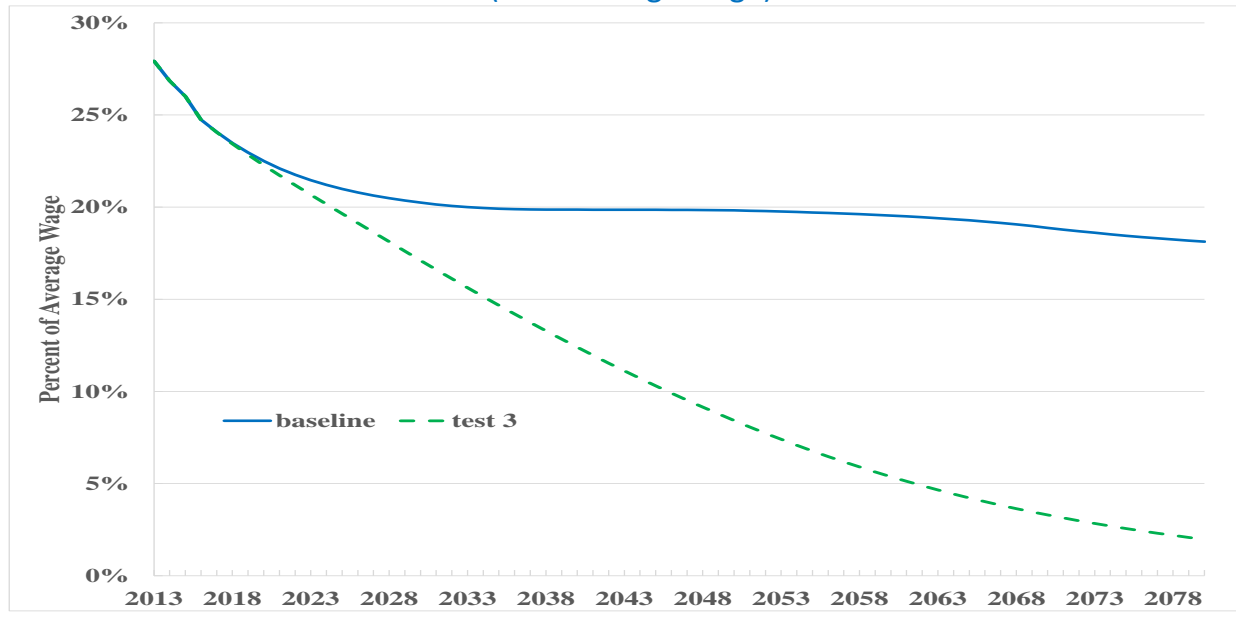

Source: World Bank estimates. 
Sensitivity Test 4: The contribution ceiling increases by PHP 200 per year ("smoothing" of PHP 1,000 every five years), with the following results:

- Initially, PHP 200 per year means growth at a rate well below wage growth and even inflation, at about one-third of the inflation rate. In the longer run, the growth rate eventually slows down to 20 percent of the inflation rate.

- As a result, the relative level of the ceiling decreases, although more slowly than in Test 3.

- Therefore, the nature of the impact is similar to Test 3 , but all effects kick in more slowly.

- The break-even and depletion points shift forward by 7 and 6 years, respectively, and the financing gap decreases from 34 percent to 17 percent.

Figure 28: $\quad$ SSS - Sensitivity Test 4: Increases in the Contribution Ceiling by PHP 200 per year Current Balance

(\% of GDP)

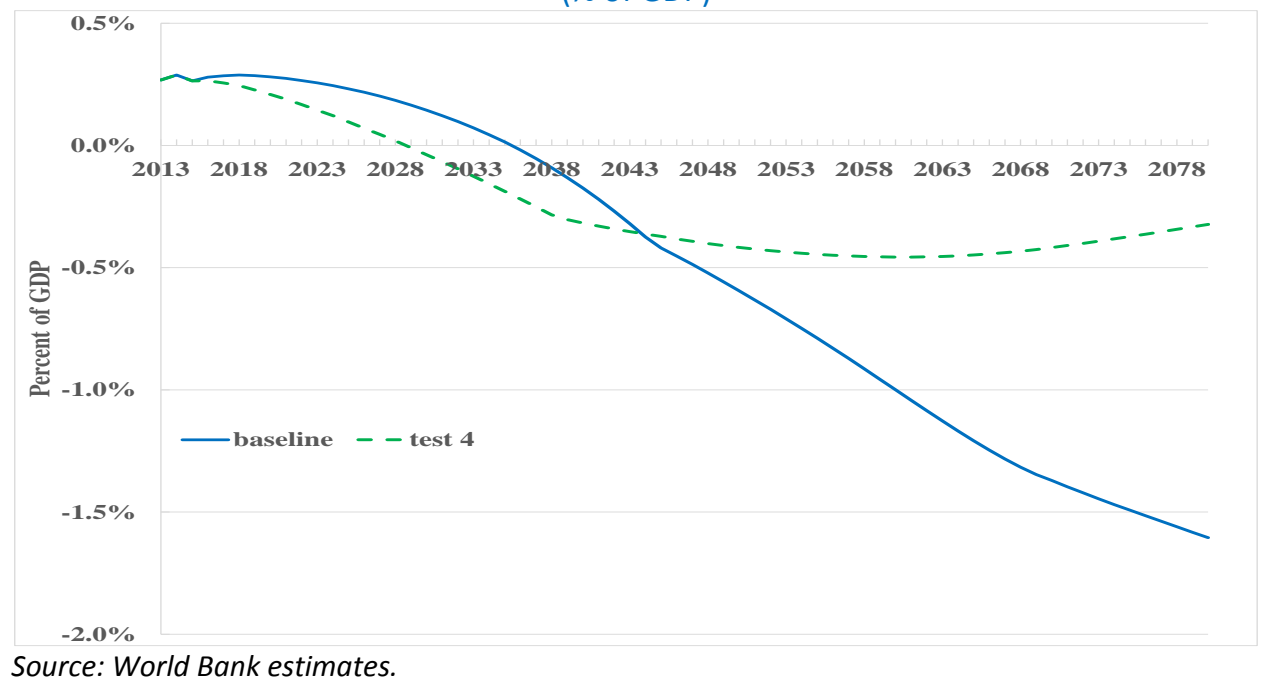

Figure 29: $\quad$ SSS - Sensitivity Test 4: Increases in the Contribution Ceiling by PHP 200 per year Replacement Rate

(Average replacement rate for new pensioners)

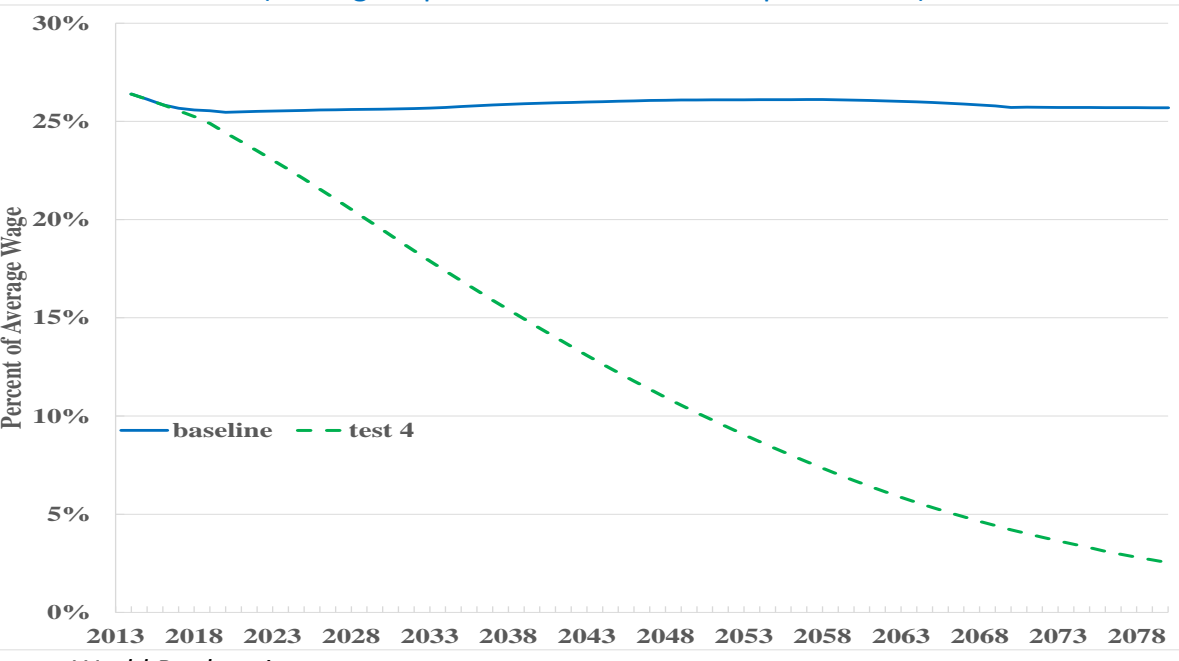

Source: World Bank estimates. 
Sensitivity Tests 5 (a \& b): For Test $5 a$, the real interest rate on pension fund investments is $3 \%$ (lower by 1 p.p.). For Test $5 b$, the real interest rate on pension fund investments is 5 percent (higher by 1 p.p.). The following effects were observed:

- Only revenues (via investment returns) are affected.

- The impact on cash flows is not dramatic: plus/minus 2 years for the break-even and depletion points.

- The discount rate used in the financing gap calculations changes the same way as the interest rate.

- The effect on the financing gap is therefore much more substantial than the effect on cash flows, with an increase from 34 percent to 57 percent in Test $5 \mathrm{a}$ and a decrease to 20 percent in Test $5 \mathrm{~b}$.

Figure 30: $\quad$ SSS - Sensitivity Test 5: Interest Rates on Pension Fund Investments Up/Down by 1 percentage point - Current Balance

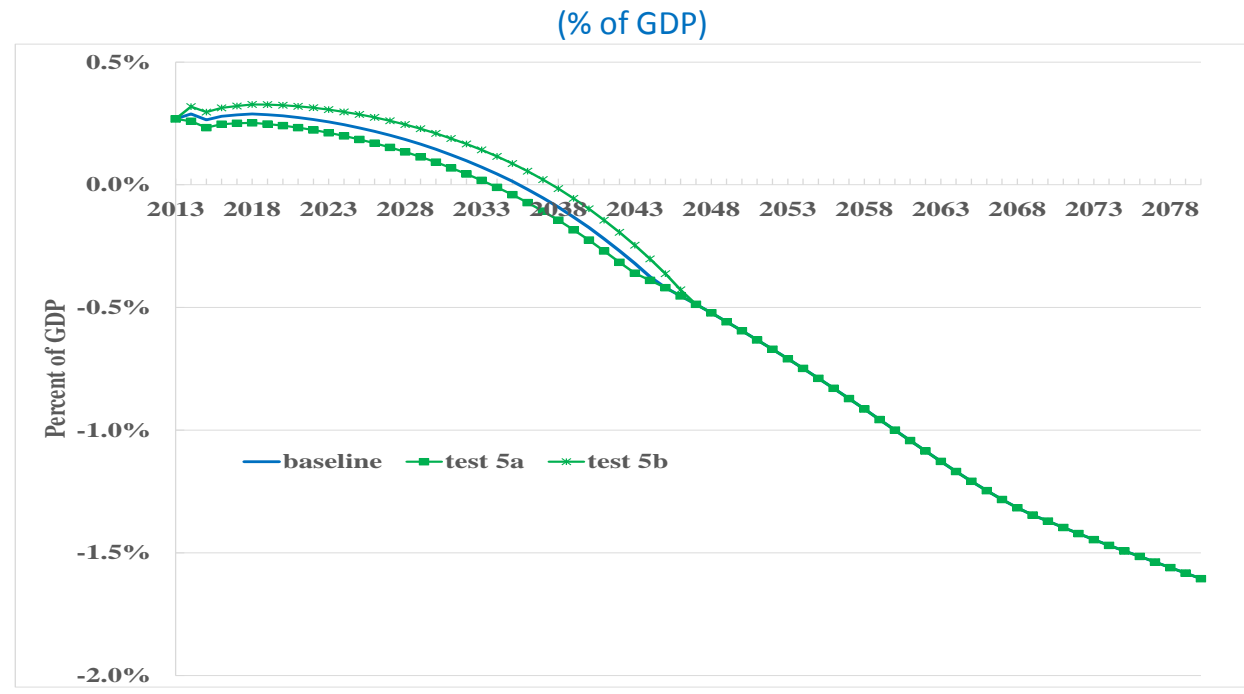

Source: World Bank estimates. 